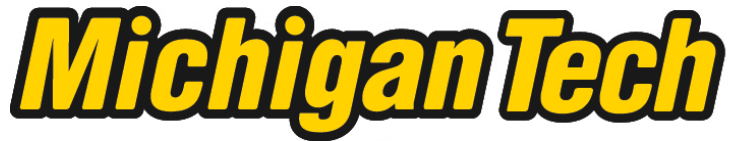 \\ Michigan Technological University Create the Future Digital Commons @ Michigan Tech
}

Dissertations, Master's Theses and Master's Reports - Open

Dissertations, Master's Theses and Master's

Reports

2012

Public values and perceptions of industrial heritage in the Keweenaw Peninsula, Michigan

Natiffany R. Mathews

Michigan Technological University

Follow this and additional works at: https://digitalcommons.mtu.edu/etds

Part of the Archaeological Anthropology Commons

Copyright 2012 Natiffany R. Mathews

\section{Recommended Citation}

Mathews, Natiffany R., "Public values and perceptions of industrial heritage in the Keweenaw Peninsula, Michigan", Master's Thesis, Michigan Technological University, 2012.

https://doi.org/10.37099/mtu.dc.etds/302

Follow this and additional works at: https://digitalcommons.mtu.edu/etds

Part of the Archaeological Anthropology Commons 


\title{
PUBLIC VALUES AND PERCEPTIONS OF INDUSTRIAL HERITAGE IN THE KEWEENAW PENINSULA, MICHIGAN
}

By

Natiffany R. Mathews

\begin{abstract}
A THESIS
Submitted in partial fulfillment of the requirements for the degree of

MASTER OF SCIENCE

(Industrial Archaeology)
\end{abstract}

MICHIGAN TECHNOLOGICAL UNIVERSITY

2012

(C)2012 Natiffany R. Mathews 
This thesis, "Public Values and Perceptions of Industrial Heritage in the Keweenaw

Peninsula, Michigan," is hereby approved in partial fulfillment of the requirements for the Degree of MASTER OF SCIENCE IN INDUSTRIAL ARCHAEOLOGY.

Department of Social Sciences

Signatures:

\begin{tabular}{cl} 
Thesis Advisor & \\
\cline { 2 - 2 } Department Chair R. Martin \\
\\
Date \\
\end{tabular}




\section{DEDICATION}

My thesis is dedicated to my mother and my husband Eric. Their support and love strengthened and encouraged me through the process of completing my project. 


\section{TABLE OF CONTENTS}

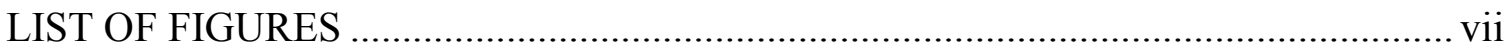

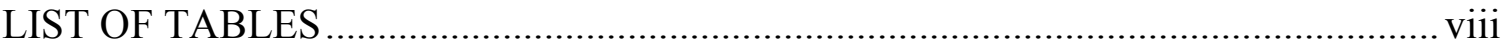

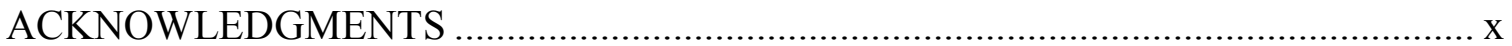

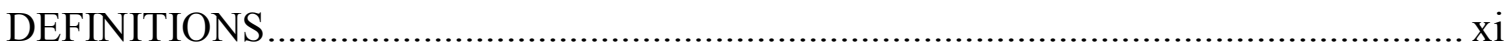

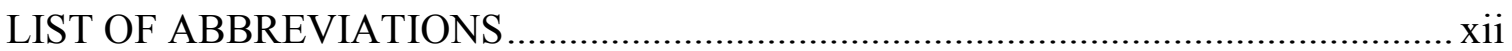

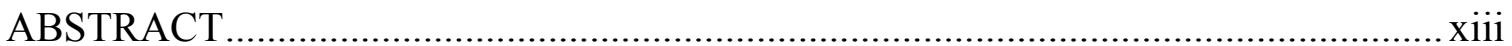

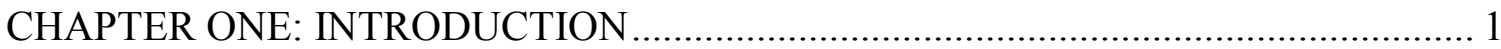

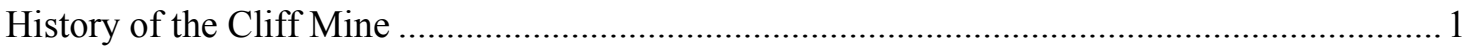

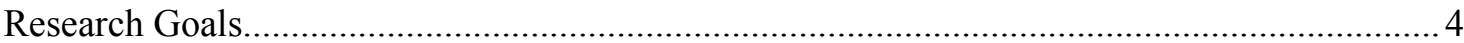

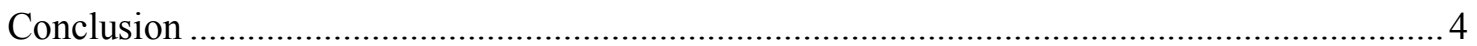

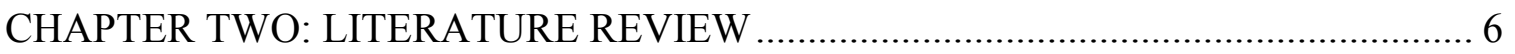

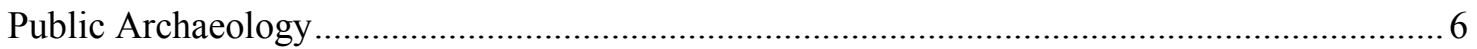

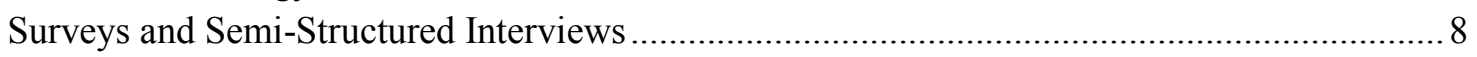

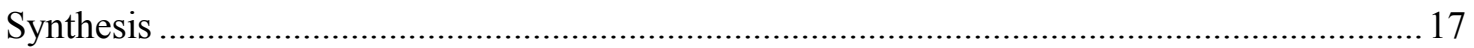

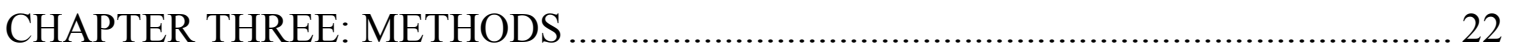

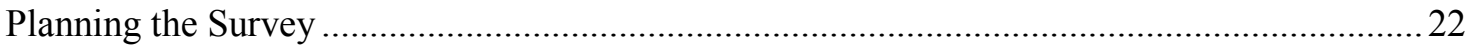

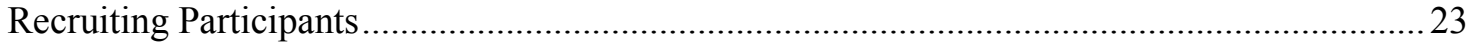

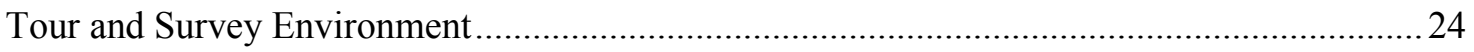

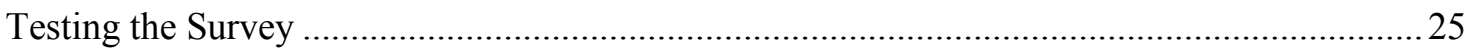

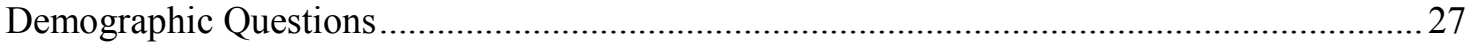

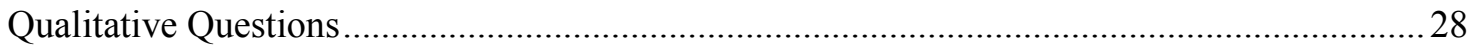

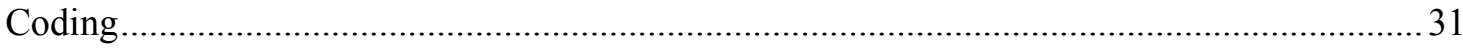

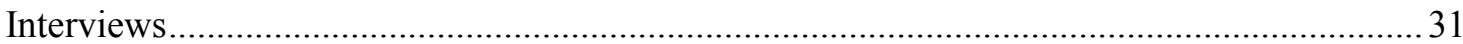

CHAPTER FOUR: SURVEY RESULTS AND DISCUSSION ................................. 33

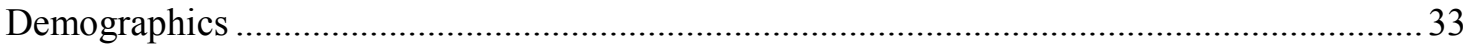

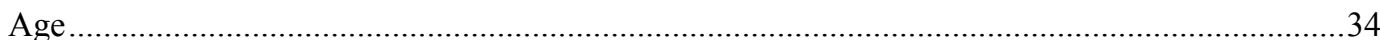

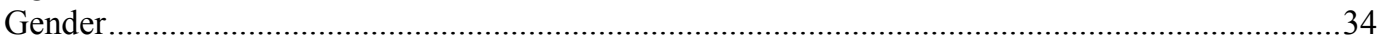

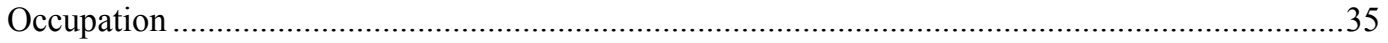

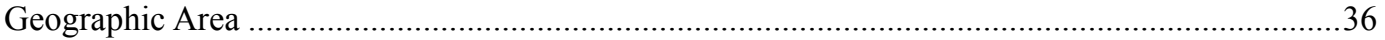

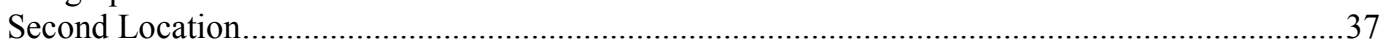

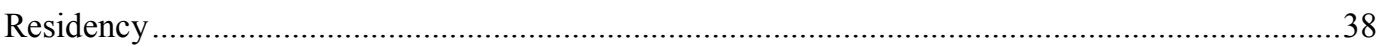

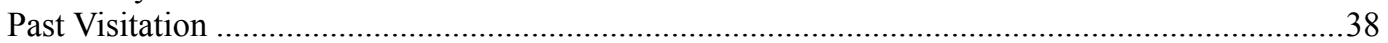

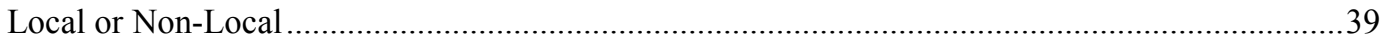

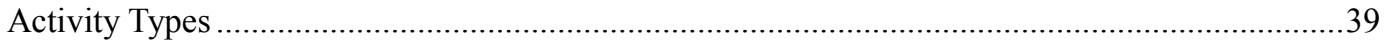

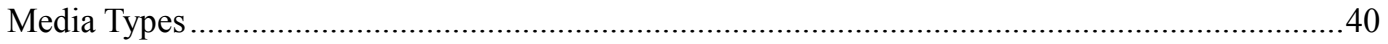

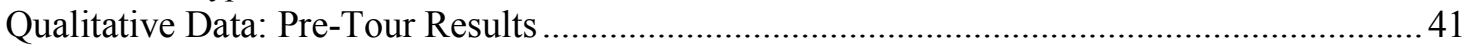

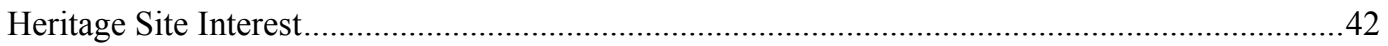

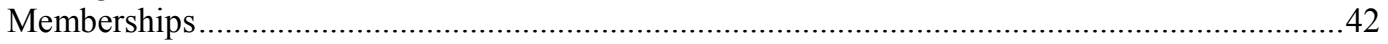

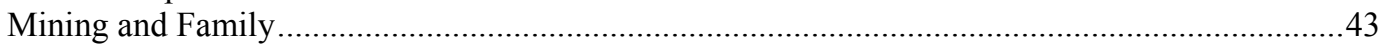

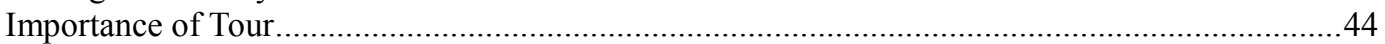

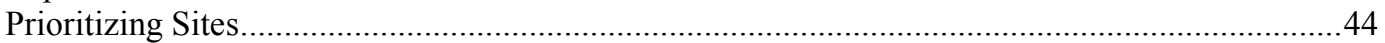

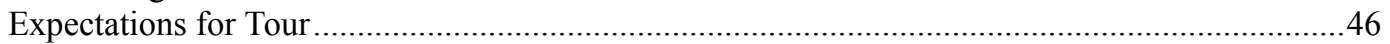




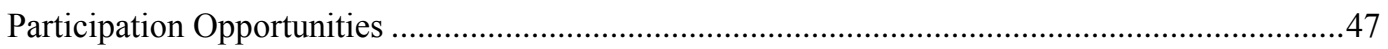

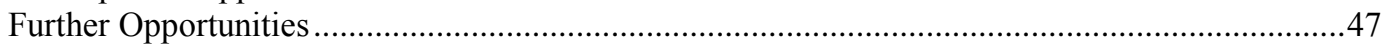

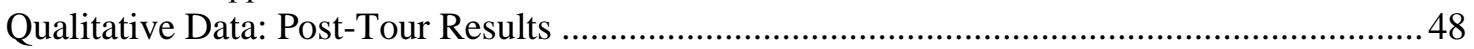

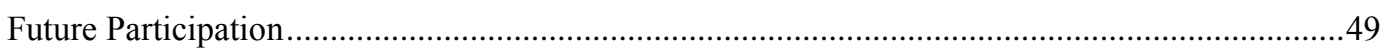

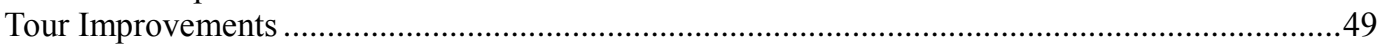

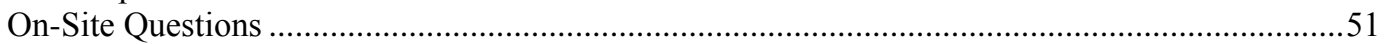

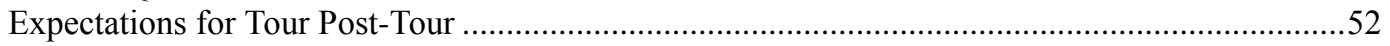

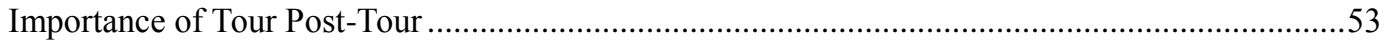

Prioritizing Sites Post-Visit ..................................................................................................5

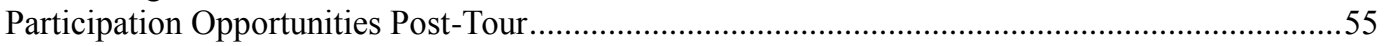

Further Opportunities Post-Tour ................................................................................................

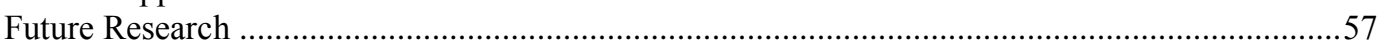

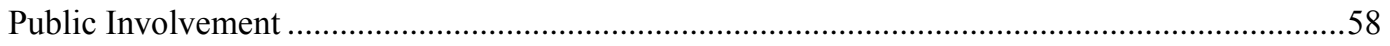

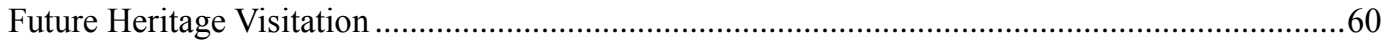

Questions and Comments...................................................................................................6

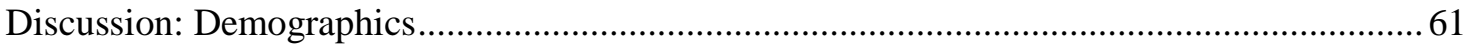

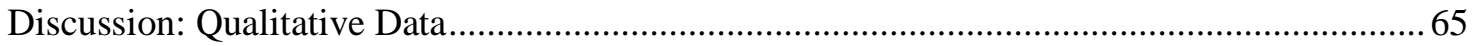

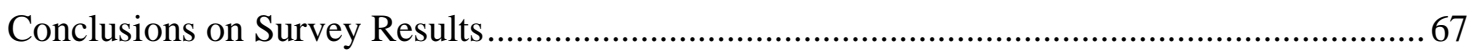

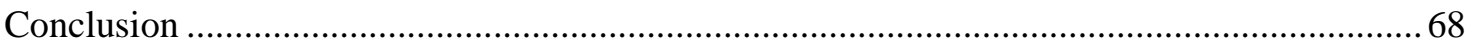

CHAPTER FIVE: INTERVIEW RESULTS AND DISCUSSION .............................. 70

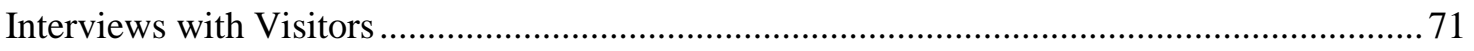

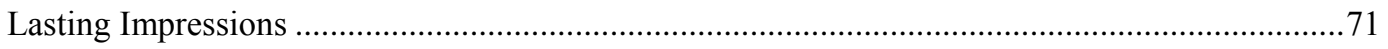

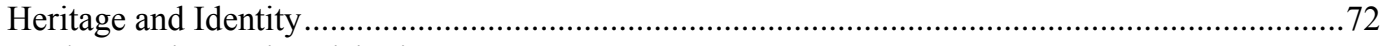

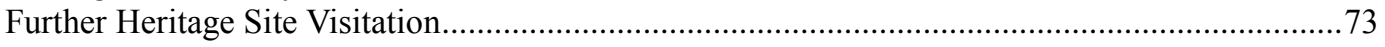

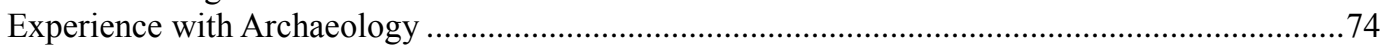

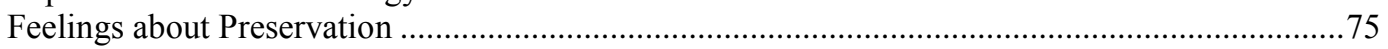

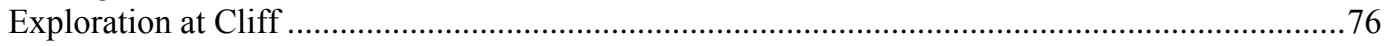

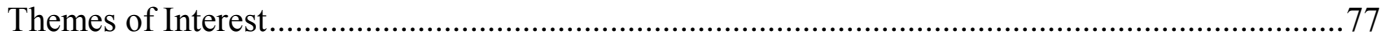

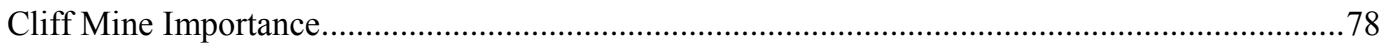

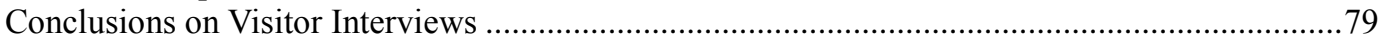

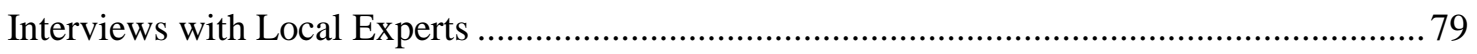

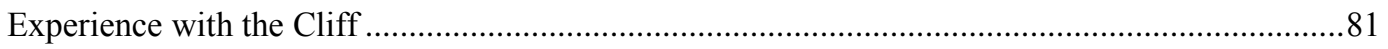

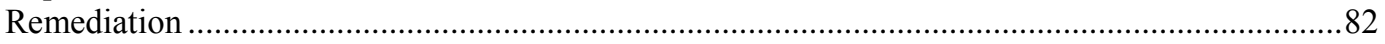

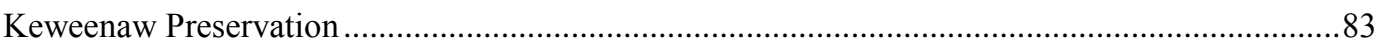

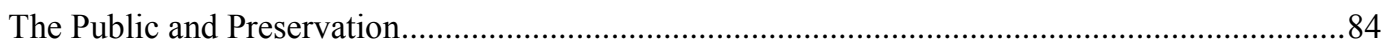

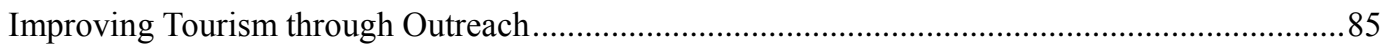

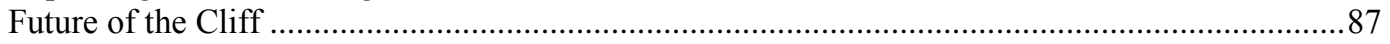

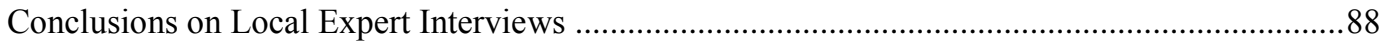

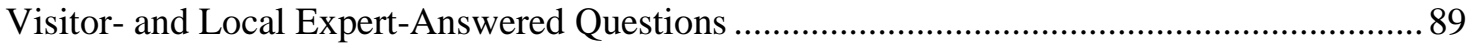

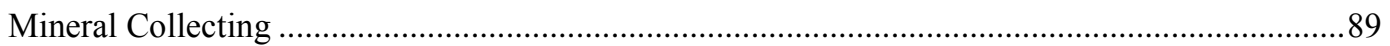

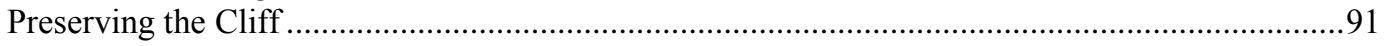

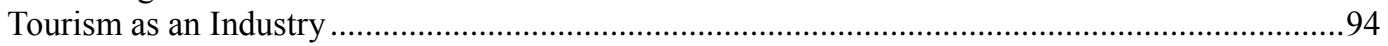

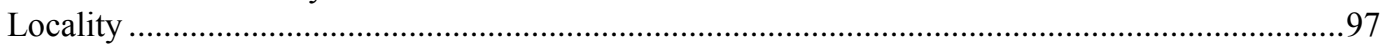

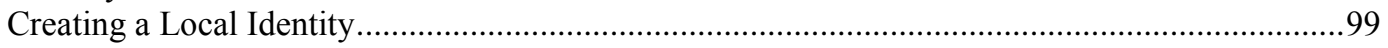

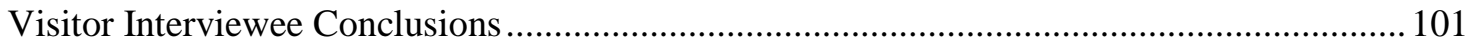

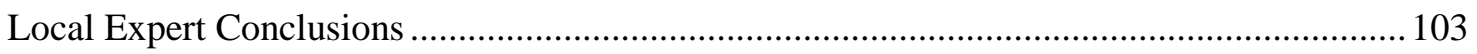

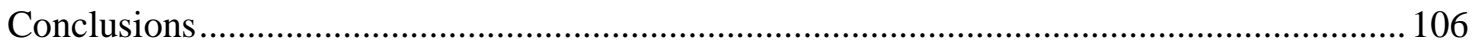

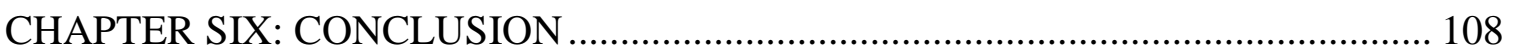

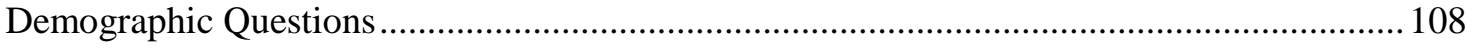

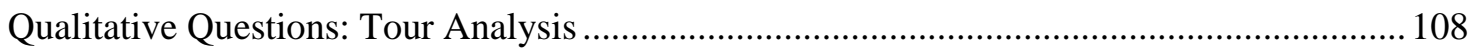




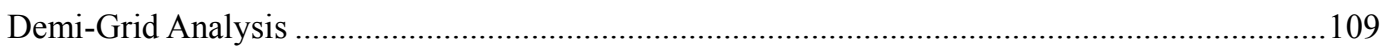

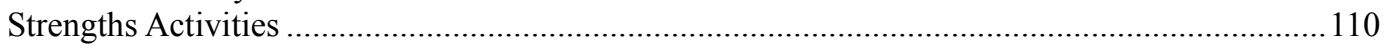

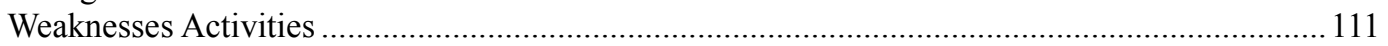

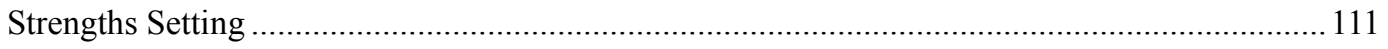

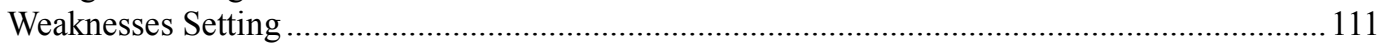

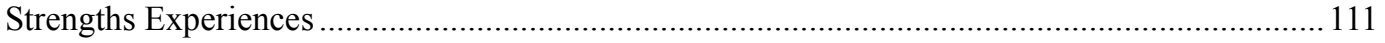

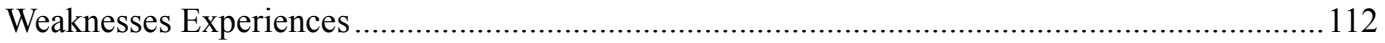

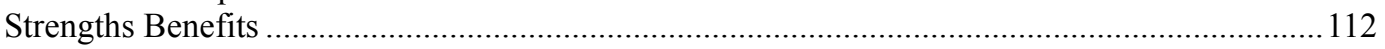

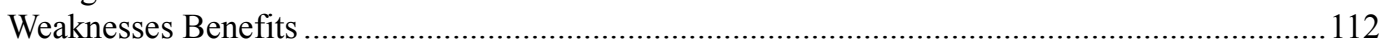

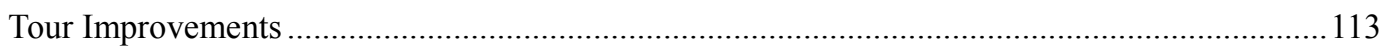

Conclusions on the Cliff Mine Survey ............................................................ 114

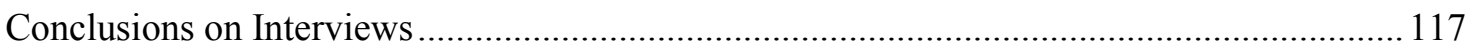

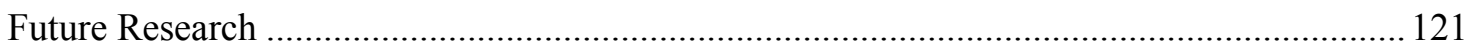

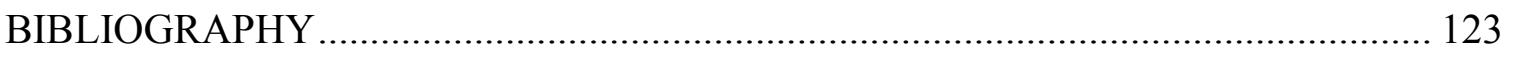

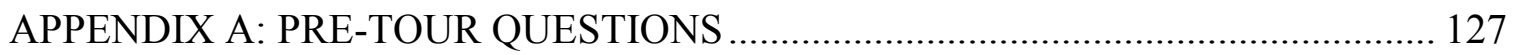

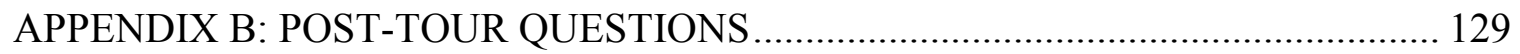

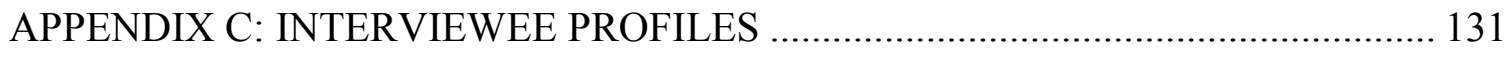

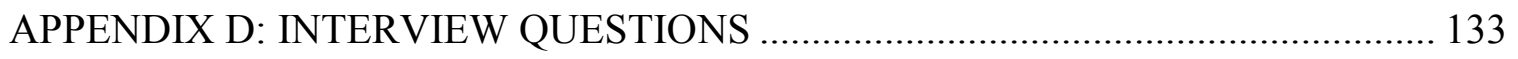

APPENDIX E: IRB AND PHOTOGRAPHIC REPRODUCTION APPROVAL ......... 135 


\section{LIST OF FIGURES}

1.1: ILLUSTRATION OF THE KEWEENAW PENINSULA, APPROXIMATING THE LOCATION OF THE CLIFF MINE TODAY, INCLUDING LOCAL VILLAGES AND CITIES

2.1: GENERAL LOCATIONS OF FEATURED NATIONAL HERITAGE PARKS AND AREAS

3.1: PHOTOGRAPH OF THE CLIFF MINE TOUR GREETING AREA ALONG CLIFF DRIVE

4.1: AGE GROUPS OF RESPONDENTS CATEGORIZED BY GENDER .35

4.2: GEOGRAPHIC AREA CATEGORIZED BY RESIDENCY AND SEPARATED BY LOCALITY

5.1: LOCAL EXPERTS ARE ARRANGED INTO THREE GROUPS FOR THE PURPOSE OF THIS STUDY; CULTURAL SECTOR, GOVERNMENT SECTOR, AND COMMERCIAL SECTOR

5.2: ILLUSTRATION OF THE KEWEENAW PENINSULA, APPROXIMATING THE LOCATION OF THE HISTORIC CENTRAL MINE AND TORCH LAKE SUPERFUND SITE.

5.3: ALL LOCAL EXPERT GROUPS (COMMERCIAL SECTOR, GOVERNMENT SECTOR, AND CULTURAL SECTOR) ARE RELATED TO EACH OTHER AS INDIVIDUALS NAVIGATE THEIR GROUP IDENTITIES 


\section{LIST OF TABLES}

2.1: REPORTED DATA FROM FOUR HERITAGE SITE SURVEY SOURCES .13

3.1: VISITOR NUMBERS AND SURVEY COMPLETION DATA …..........................23

4.1: FREQUENCY TABLE REPRESENTING RESPONSES FOR AGE ......................34

4.2: FREQUENCY TABLE REPRESENTING RESPONSES FOR GENDER ..............34

4.3: FREQUENCY TABLE REPRESENTING RESPONSES FOR OCCUPATION........36

4.4: FREQUENCY TABLE REPRESENTING RESPONSES FOR GEOGRAPHIC

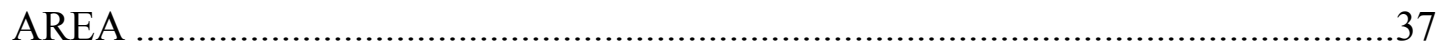

4.5: FREQUENCY TABLE REPRESENTING RESPONSES FOR SECOND LOCATIONS

4.6: FREQUENCY TABLE REPRESENTING RESPONSES FOR RESIDENCY .........38

4.7: FREQUENCY TABLE REPRESENTING RESPONSES FOR PARTICIPANTS

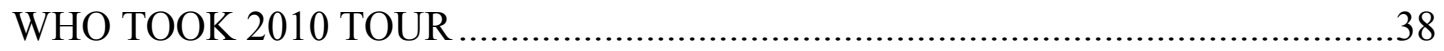

4.8: FREQUENCY TABLE REPRESENTING RESPONSES FOR LOCALITY ...........39

4.9: FREQUENCY TABLE REPRESENTING RESPONSES FOR ACTIVITY TYPES

ENJOYED AT THE CLIFF SITE ..................................................................... 40

4.10: FREQUENCY TABLE REPRESENTING RESPONSES FOR MEDIA TYPES ...40

4.11: HERITAGE SITE INTEREST: PRE-TOUR QUESTION 2 CODED RESPONSES

4.12: MEMBERSHIPS: PRE-TOUR QUESTION 3 CODED RESPONSES ...................42

4.13: MINING AND FAMILY: PRE-TOUR QUESTION 4 CODED RESPONSES ......43

4.14: IMPORTANCE OF TOUR: PRE-TOUR QUESTION 5 CODED RESPONSES....44

4.15: PRIORITIZING SITES: PRE-TOUR QUESTION 6 CODED RESPONSES.........45

4.16: EXPECTATIONS FOR TOUR: PRE-TOUR QUESTION 7 CODED RESPONSES

4.17: PARTICIPATION OPPORTUNITIES: PRE-TOUR QUESTION 9 CODED

RESPONSES

viii 
4.18: FURTHER OPPORTUNITIES: PRE-TOUR QUESTION 10 CODED

RESPONSES

4.19: FUTURE PARTICIPATION: POST-TOUR QUESTION 1 CODED RESPONSES

4.20: TOUR IMPROVEMENTS: POST-TOUR QUESTION 2 CODED RESPONSES .50

4.21: ON-SITE QUESTIONS: POST-TOUR QUESTION 3 CODED RESPONSES......51

4.22: EXPECTATIONS FOR TOUR POST-TOUR: POST-TOUR QUESTION 4

CODED RESPONSES

4.23: IMPORTANCE OF TOUR POST-TOUR: POST-TOUR QUESTION 5 CODED

RESPONSES

4.24: PRIORITIZING SITES POST-TOUR: POST-TOUR QUESTION 6 CODED RESPONSES

4.25: PARTICIPATION OPPORTUNITIES POST-TOUR: POST-TOUR QUESTION 7

CODED RESPONSES

4.26: FURTHER OPPORTUNITIES POST-TOUR: POST-TOUR QUESTION 8

CODED RESPONSES .56

4.27: FUTURE RESEARCH: POST-TOUR QUESTION 9 CODED RESPONSES .57

4.28: PUBLIC INVOLVEMENT: POST-TOUR QUESTION 10 CODED RESPONSES

4.29: FUTURE HERITAGE VISITATION: POST-TOUR QUESTION 11 CODED RESPONSES

6.1: ASEB DEMI-GRID ANALYSIS USING RESPONSES FROM CLIFF MINE TOUR SURVEYS 110

6.2: REPORTED DATA FROM FIVE HERITAGE SITE SURVEY SOURCES 115 


\section{ACKNOWLEDGMENTS}

I have many people to thank for the completion of this work. I would first like to thank my advisor, Dr. Susan Martin, for her amazing advice, fruitful discussion, and invaluable help. Dr. Martin had immeasurable patience with me during my two years at MTU and I will be eternally grateful for her help. I would also like to thank my committee members, Dr. Timothy Scarlett, Dr. Samuel Sweitz, and Dr. Patricia Sotirin for their time and assistance in completing this work. Sean Gohman provided much of the information about the Cliff Mine and was supportive of my work for which I am thankful. I thank Mark Dice for offering his photographs of the Cliff Mine field school for my use in presentations and publications. Most important of all are my survey respondents and interviewees. To all of you, a huge thanks and much gratitude! You are what make the Keweenaw such a special and important place. 


\section{DEFINITIONS}

class. An economic division between types of employment; a social identity such as "working class" which defines people from a particular occupational history or heritage.

mineral collecting. The act of acquiring mineral specimens.

poor rock.

Colloquial term for the mineral waste from underground mining activity. As a feature on the landscape, collected poor rock is termed: mineral piles; poor rock piles; rock piles; tailings; waste rock piles.

stamp sand.

Pulverized poor rock waste that is produced through mechanically crushing ore through a stamp mill. Also: tailings.

tailings.

Generic term for fine mining waste. 


\section{LIST OF ABBREVIATIONS}

The following abbreviations are used throughout the text.

$\begin{array}{ll}\text { C\&H } & \text { Calumet \& Hecla Mining Company } \\ \text { KCHS } & \text { Keweenaw County Historical Society } \\ \text { KCRC } & \text { Keweenaw County Road Commission } \\ \text { KNHP } & \text { Keweenaw National Historical Park } \\ \text { MTU } & \text { Michigan Technological University } \\ \text { USGS } & \text { United States Geological Survey }\end{array}$




\begin{abstract}
The purpose of this research is to assess public values and perceptions concerning industrial heritage in the Keweenaw by studying visitors at an endangered mining site tour. This research presents and analyzes feedback collected directly from participants in the Cliff Mine (Michigan) archaeological field school public tour surveys in June 2011, gathers semi-structured interview data from survey participants and local experts, and synthesizes and collates both survey and interview data. As those who study heritage site visitors have found, in all outreach there is a necessity for deeper understanding of visitors for the outreach to be effective. An appropriate metric for collecting public values and opinions was created and used at the Cliff Mine archaeological field school public tours.

To accomplish research goals, an opinion survey was created to collect demographic information and qualitative feedback from visitors at the Cliff Mine field school. The survey, a pre-tour and post-tour question list, found that all visitors who filled out a survey supported preservation and most were adults over 46 years of age. Most visitors were white-collar professionals, identified as local residents, and found out about the tour through the newspaper. Interview questions were constructed to supplement and expand on the visitor survey results. In addition, local experts involved in Keweenaw heritage were interviewed. All interviewees supported heritage preservation but often had conflicting views when activities such as mineral collecting were factored into the preservation question. By analyzing responses to the survey and interviews, improvements to outreach efforts at the Cliff Mine are recommended. Future research should further explore perceptions of social class and identity, and should seek out stakeholders not contacted through this research, in order to improve outreach and include all community groups.
\end{abstract}




\section{CHAPTER ONE \\ INTRODUCTION}

Archaeological field schools rarely collect public input and values about the site being researched or about the effectiveness of their outreach strategy. Assumptions abound about the perceptions and attitudes that the public holds, specifically concerning their involvement in archaeological fieldwork. There is scant research specifically targeting these issues in the fields of historical and industrial archaeology. Nor do heritage experts necessarily concern themselves with archaeological field schools and their public impacts.

The goal of this project is to understand the perceptions and values that some interested members of a local community hold regarding local mining heritage. To accomplish these goals, an opinion survey was created to collect demographic information and feedback during the archaeological field school tours. Contact information was collected from willing survey participants for future interviews. After an initial analysis of survey data, interview questions were constructed to supplement and expand on the survey results for visitors. Local experts who have personal and professional investments in local heritage were interviewed with a different set of interview questions. In this project, I will present and analyze feedback collected directly from participants in the Cliff Mine (Michigan) archaeological field school public tour surveys, present and analyze semi-structured interview data from survey participants and hand-picked local experts, and synthesize and collate both survey and interview data.

\section{History of the Cliff Mine}

To understand the importance of the Cliff Mine site, some background is needed on the past use of the site. The Cliff Mine, colloquially known as 'The Cliff,' is located in Allouez Township, Keweenaw County, Michigan (FIGURE 1.1). Located in the Keweenaw Peninsula, a 'finger' of land rising up from the Upper Peninsula of Michigan, the site consists of a quarter-mile long volcanic precipice lined with coniferous trees. The Cliff area is well-known and loved by locals who have used the site for a variety of 


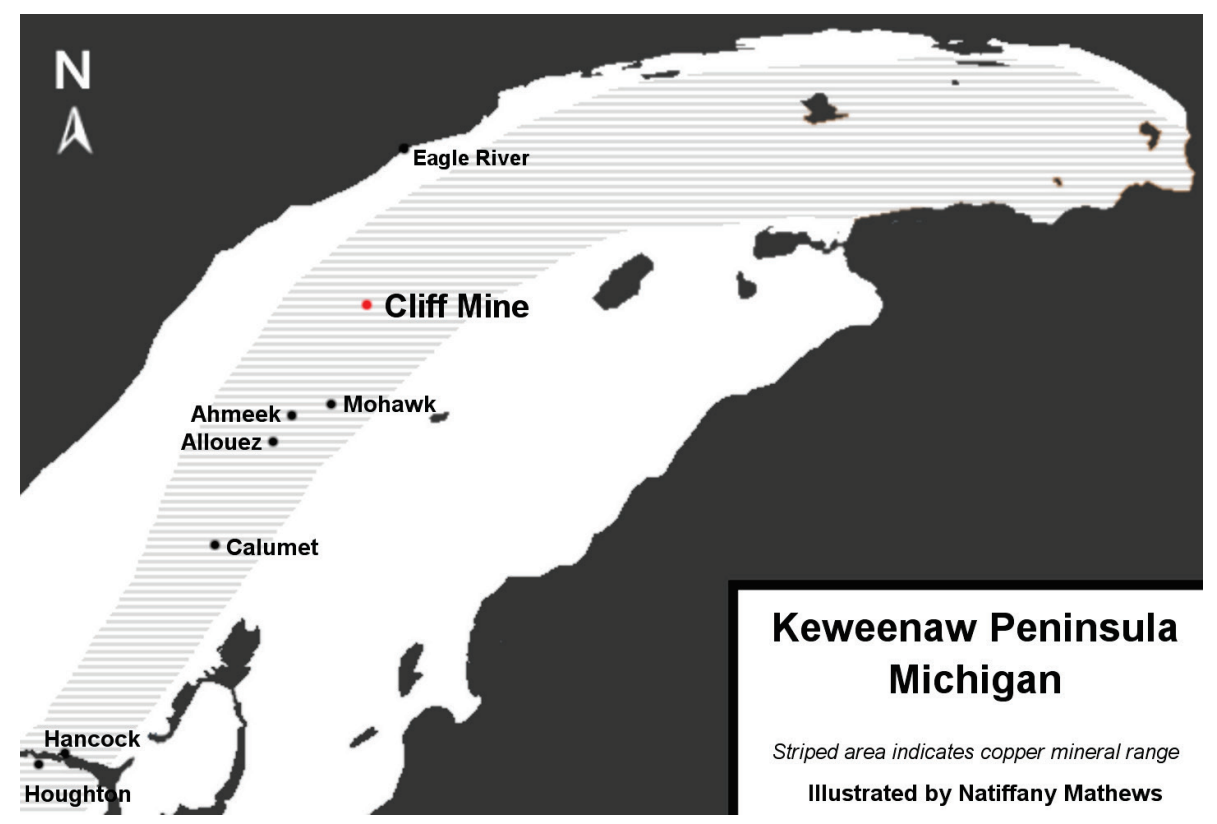

FIGURE 1.1: Illustration of the Keweenaw Peninsula, approximating the location of the Cliff Mine today, including local villages and cities (illustration by the author based on USGS data).

outdoor activities since its industrial abandonment around the time of the Great Depression. Beginning in about 1845, the Cliff Mine produced for the Pittsburgh and Boston Mining Company, which shed its other stakes to concentrate all their mining efforts and capital at the site (Gohman 2010:35-83).

Cliff Mine was world renowned as a prolific copper producing mine until 1870 (Gohman 2010:35-83). Anecdotally, some locals believe that the largest mined piece of copper mineral came from the Cliff Mine despite a lack of information to prove this myth. Silver deposits were also found at the Cliff but in small amounts; this did not stop locals from creating a myth about a Wall of Silver (Gohman 2010:41). Cliff had one of the first company-built towns in the Keweenaw, which was called Clifton and housed the miners and their families. The Cliff Mine is well known by historians and industrial history enthusiasts as the first copper mine in the region to yield profits to investors. It remained consistently profitable until 1870 (Gohman 2010:35-83; Chaput 1971).

After the Cliff Mine stopped production, the company was reorganized as the Cliff Copper Company in 1872. This phase lasted until 1876, when 'tribute' mining 
picked up at the Cliff until 1879. The site was probed and prodded by various mining companies until Calumet \& Hecla (C\&H) purchased the Cliff Mine property in 1910. Mining operations at this time were marginally successful at best and in 1932, operations by $\mathrm{C} \& \mathrm{H}$ ceased at Cliff. Building foundations and cement features remain on the landscape from this era (Gohman 2010:81-83).

The industrial culture of the Keweenaw Peninsula is distinctive in the United States. The Keweenaw boasts the largest deposits of elemental copper, colloquially called 'native copper,' in the world with much of it still embedded underground in layers of basalt. Copper mining began in earnest in the mid-to-late $19^{\text {th }}$ century, slowing significantly in the 1920s (Lankton 2010:208). Laborers came from around the United States and the world to settle in the Keweenaw to work in the copper mining industry (Lankton 2010:176-7). This industry remains so central to the heritage and identity of Keweenaw residents that the Keweenaw National Historical Park was established in 1992 to attract visitors to the area, provide curation and preservation for the area's heritage, and education and outreach to the community. In addition to the material heritage of the area, Keweenaw residents and descendants of copper mining families offer incredibly variable and valuable perspectives that researchers continue to 'mine'.

Research conducted at the Cliff Mine by the Michigan Technological University (MTU) Social Sciences Department began several decades ago. An archaeological field school was conducted in 1973 by Dr. Eleanor DeLing Andrews and was supervised by Maria Campbell as a part of an archaeology course, the first at MTU (DeLing Andrews 2005). More recent research was organized by Dr. Patrick Martin and a field season was planned in 2010. The 2010 field season included both a field school and SRM survey, supervised by Dr. Timothy Scarlett and Dr. Sam Sweitz, which produced data, feature maps, and initial research into the locations of the Cliff Mine-era stamp mills. This research proved helpful when in 2011, another field season began at the Cliff Mine with its focus set on the second and largest stamp mill built for the Cliff Mine. The 2011 field school lasted from May 9th until June 23rd. Led by PhD student Sean Gohman, field school students from MTU and Central Michigan University excavated part of the structure. 


\section{Research Goals}

This project was outlined with three research questions in mind: what were Cliff Mine tour visitor perceptions and values related to industrial heritage and archaeology; how were these perceptions and values shaped by visitorship and identity; and how did community stakeholder group memberships influence the values and perceptions of industrial heritage among local professionals? These questions became research goals and drove the structure of the research, creating three distinct groups of data.

Three data collection methods were used to achieve the research goals of this project. The survey questions were the primary method of gathering information on visitor perceptions of local heritage, how visitors valued the Cliff Mine and industrial history, and what visitors expected from the archaeological tour. Semi-structured interviews with tour participants were conducted to expand on and add to interviewee answers from the survey. Finally, focused interviews with local experts contributed perspectives on heritage and preservation from professionals in the Keweenaw area.

Chapter Two discusses the relevant literature on the history of public archaeology, survey methods at archaeological and heritage sites, and the unique nature of conducting survey research on the heritage of the industrial past. Chapter Three details the methods used for constructing the Cliff Mine survey and why a pre- and post-tour format was used. The reasoning behind collecting demographic and qualitative data are discussed. Also included are methods for interviewing participants and local experts. In Chapter Four, survey data are presented and analyzed, including demographics and the pre-tour and post-tour qualitative results. Chapter Five contains responses from semi-structured interviews with two groups: survey respondents and local experts. Closing this research is Chapter Six, a synthesis of the gathered data which presents conclusions about demographic, qualitative, interview data, and further research needs.

\section{Conclusion}

The Cliff Mine is a unique and important place in the mining history of not only the Keweenaw, but the United States. The 2011 summer archaeological field school at the Cliff Mine presented an opportunity to collect data which is helpful in the ongoing quest 
to preserve this area for the future. More importantly, the collected data represent the ideas of a public that is invested in this future, a complex public that is often neglected in academic scholarship. 


\section{CHAPTER TWO LITERATURE REVIEW}

A broad search for relevant literature was undertaken to understand the need for stakeholder surveys of public archaeological undertakings. The following chapter details such literature from the fields of archaeology, heritage management and tourism, and the study of industrial places. Academic works and publications by public institutions contributed to the following literature review and reinforced the need for further exploration into the realm of public inquiry in heritage studies and archaeology.

\section{Public Archaeology}

The practice of archaeology in the United States changed drastically in the 1970s as cultural resource management professionals (and academics) pushed for publicallysupported preservation and stewardship laws. With these changes, several archaeologists published guidelines for interacting with the public, a difficult task as, at the time, many professionals saw non-archaeologists as a part of the preservation problem (Lipe 1974; McGimsey 1972:6). With an increasing focus on educating the public about the benefits of archaeology, such guidelines on public outreach and collaboration became necessary. As Charles McGimsey pointed out in Public Archaeology, if the public is not involved or educated in archaeology then they will have no reason to invest in it, financially or ideologically (McGimsey 1972:37).

There were issues with McGimsey's and other early public archaeologist's definitions of 'public archaeology' which can be attributed to the early applications of outreach in the federally-supported Cultural Resources Management (CRM) sphere. Barbara Little identified three contemporary 'types' of public archaeology in the United States with the first type based in CRM, the second as outreach to promote stewardship of the archaeological record, and third, to "help communities or individuals in some way [to] solve societal problems" (Little 2009:30). Even as these types manifested as public archaeology types, they also overlapped. This interplay between public archaeology types is an important characteristic of how public archaeology is done contemporarily (Little 2009:30). 
Barbara Little's second and third 'types' of public archaeology were identified by Nick Merriman as the 'deficit' and 'multiple-perspectives' models of public archaeology (2004:5-8). The 'deficit model' was a conceptualization of public archaeology in line with what McGimsey advocated, with an emphasis on educating the public in return for their financial and ideological support. The 'multiple-perspectives model' took into account the many ways the public can understand archaeology through personal experience and how communities can be supported through archaeology (2004:6-8). Merriman proposed that archaeologists need to incorporate both of these models to be successful at public outreach (2004:7-8). This approach is best suited for archaeology conducted at field schools because field seasons need local and financial support but also can engage the community in a mutually beneficial relationship.

The path most frequently taken in archaeological outreach shows the public what you want them to see, "without giving careful consideration to the social agendas embedded within our own interpretation," (Potter 1997:37). This lack of self-reflection elevated discourse with the public to a higher importance to avoid such a self-contained outreach philosophy. The professional responsibility in building constructive dialogues and relationships with the public lay with archaeologists themselves (Little 2002:3). Of particular importance to the communication between non-archaeologists and archaeologists is the fact that the data are largely inaccessible or too technical for the public (Lipe 2002:20). Building such discourse can result in a mutually beneficial relationship, such as the relationship between the Eastern Pequot Tribal Nation and archaeologists in Connecticut. Archaeologists sought to provide historical information about the Pequot to the Pequot, and used the acts of research and excavation to enrich the lives and cultures of local people (Silliman and Sebastian Dring 2008:69-76).

Related to the 'multiple-perspectives model' was the 'critical theory model' utilized by Archaeology in Annapolis in their public archaeology programs for nearly three decades (Potter 1994:2). Critical theory in archaeology acknowledged the different perspectives and 'lenses' with which people view the world as valid and encouraged archaeologists to be self-reflexive about their own viewpoints. This approach to public outreach allowed participants to engage in the archaeological process on a different level 
than that of a teacher and student (Moyer 2007:274-5). Participants and archaeologists engaged in a critical theory approach were encouraged to question information presented to them and to question their own biases and perceptions critically (Potter 1994:2).

However, archaeologists are professionals trained in conducting archaeological science and analysis and should be able to present information in a way that reflects archaeological standards and principles (Potter 1994:199-200). Archaeologists should be clear about what is acceptable and unacceptable in our field while also making sure that we do not alienate those who engage in activities or hold beliefs with which we are not comfortable (Zimmerman 2007:73-7). When working with the public, this line can be incredibly difficult to walk but it is important that archaeologists engage in dialogues with the public and not create barriers between 'us' and 'them' (Zimmerman 2007:77-9).

Archaeologists must strike a balance between presenting their work as professional and remaining sensitive to and cognizant of the public's needs. The first step is to understand how current public outreach is functioning for the people engaging in it. To do this, archaeologists must employ various metrics to find out who is interested in their public outreach programs and why. Learning about one's audience can assist in crafting a more effective outreach strategy and will highlight people who are either not being reached or who are opting to stay away. Creating metrics to learn about one's audience is not standard practice among archaeologists, particularly at a field school. Such courses are traditionally meant to train students in archaeological methods and not necessarily to train students in public outreach.

\section{Surveys and Semi-Structured Interviews}

Opinion surveys are an inexpensive way of creating such a metric at an archaeological site. Parker B. Potter had mixed results when conducting opinion surveys at two different sites in the Archaeology in Annapolis program. At the free Shiplap House site tour in Annapolis, Maryland in 1985, Potter used an 'evaluation form' with one question posed to visitors. Potter asked: 'What did you learn about archaeology that you did not know before you visited the site?' The majority of Potter's respondents expressed an understanding of what the tour intended to educate them on, proving the single- 
question 'evaluation form' a successful metric for gauging this tour's effectiveness (Potter 1994:201-5).

Potter took the 'evaluation form' from the Shiplap House site tour and, in 1986, added two questions for the Main Street Annapolis site tour. These additional questions asked visitors to make connections between the site and present-day life and asked them directly what they learned, but in a way that Potter hoped would elicit a thoughtful response. The purpose of this questionnaire was to understand how visitors engaged with the tour, particularly as an "active and thoughtful consumption of historical information" (Potter 1994:205-11). Potter's results indicated that the intended message for participants was not getting through. He also found that some of the visitors regurgitated clichés about history instead of thinking critically about what was presented to them. Potter did not assess visitor values from these surveys, though, and did not aim to.

In "Emergent Industrial Heritage: The Politics of Selection," Catherine M. Cameron chronicled efforts at revitalization in Bethlehem, Pennsylvania. A onceprosperous steel manufacturing town, plans were made in Bethlehem to build a large museum of industry which was bankrolled by the Bethlehem Steel Company. In addition to the museum, efforts were made at revitalization in industrial sections of the town. Cameron interviewed several residents who were both excited by and alienated by the project, including city planners, councilpersons, and local citizens of all economic backgrounds (Cameron 2000). Of all the groups, the most affected by industrial changes were the workers left jobless and without local prospects for work, such as several of Cameron's informants. Cameron offered viewpoints from many sides of the issues presented and captured the uncertainty and trepidation of a once-great town in flux.

Cameron returned to Bethlehem to survey visitors at revitalized industrial spaces in the city. In "Excursions into the Un-Remebered Past: What People Want from Visits to Historical Sites," Catherine M. Cameron and John Gatewood (2000) examined the outcomes of an opinion survey conducted in Bethlehem, Pennsylvania. Cameron and Gatewood used this survey to understand the "underlying motivations" and values held by visitors at the revitalized downtown area (2000:109). One particular value that the authors sought was a phenomenon they termed numen, meaning a spiritual or emotional 
experience in connection with natural and historical places and objects.

Cameron and Gatewood found that local and non-local respondents were significantly distinguishable by education and that most respondents were generally welleducated and older than 30 years of age. Respondents overwhelmingly indicated a "general interest in visiting historic sites" and were even more "likely to visit historic sites while traveling." When Cameron and Gatewood analyzed answers to qualitative questions, they found that approximately $27 \%$ of respondents "clearly indicated that they desire some sort of personal experience" when they visited historic sites (2000:118). As in their analysis on the difference between local and non-local respondents, the authors found that the only statistical difference between numen-seekers and everyone else was that numen-seekers were slightly more educated.

The authors critiqued the status quo in heritage and historical site survey methods, particularly the shallow demographic-only survey, a technique which failed to build a holistic understanding of visitors and what they valued. Cameron and Gatewood's eventual conclusion that people were more likely to visit historic and heritage sites while traveling would be lost without a detailed survey such as theirs. The authors also probed respondents about what essential elements needed to be at a site and what people would have liked to see. As Cameron and Gatewood proved, what visitors want should be coming from the opinions of visitors themselves.

Carol McDavid created a website in which collaborative agents create dialogues through feedback forms and forums. Her work changed the ways public outreach was conducted. McDavid planned the construction of the website utilizing a philosophically pragmatic approach. Using 'conversation' as a metaphor deeper than simple communication, the website, which was specifically about the Levi Jordan Plantation in Brazoria, Texas, was a case study in engaging the public about interpretation and creating dynamic dialogue through reflexivity, multi-vocality, and interactivity (McDavid 2002:307).

McDavid's project ultimately came to symbolize the limitations of an internet site in the realm of public outreach as the website received plenty of feedback and engaged visitors, but failed to incite those visitors to challenge the story being presented 
(McDavid 2002:310-1). These results were similar to Potter's Shiplap House survey, examining how the public regarded the message of history coming from the authority of archaeologists. In the end, McDavid experienced difficulty reaching out to those who were not already interested in history and archaeology, and neglected to gauge visitor values.

Visitor values meant something very different to survey researchers Daniel J. Stynes and Ya-Yen Sun. The Department of Park, Recreation, and Tourism Resources at Michigan State University published a series of reports by Stynes and Sun (2004a, 2004b, 2005 ) detailing surveys that measured the demographic profiles and economic impacts of visitors to publically- and privately-owned heritage sites across the United States. The primary purpose of these surveys was to understand the economic impacts of the heritage areas on the local economies by measuring how much money visitors spent to visit the sites. Three of these studies, all from industrial heritage areas, were examined for an idea of what important similarities the visitors shared.

Lackawanna Valley National Heritage Area (LVNHA) is located in northeastern Pennsylvania in an historic anthracite coal mining region (FIGURE 2.1). The LVNHA Visitor Survey, conducted by Stynes and Sun (2004b), surveyed 271 visitors at LVNHA heritage sites, with 49 of those participants sending in additional survey responses by mail. The authors found that $62 \%$ of respondents resided in Pennsylvania and that $61 \%$ identified their gender as female. The overwhelming majority of respondents listed their race as white, $59 \%$ had a graduate degree, and $59 \%$ of respondents indicated their age above 56. Many of the visitors (63\%) made the trip to the area to visit coal mining and steampower-related heritage attractions. What these findings indicated was that visitor interest in this mining and industry national heritage area seemed to generally be from professionals near or of retirement age who also resided within the state of Pennsylvania (Stynes and Sun 2004b). The majority of visitors from Pennsylvania are interesting considering LVNHA is neighbored by New Jersey and New York (FIGURE 2.1). Chesapeake and Ohio Canal National Historical Park (C\&O Canal NHP) is not a 'typical' historic site in that it is comprised of property on the Chesapeake and Ohio Canal, which runs along the Potomac River from Cumberland, Maryland to Washington, D.C 


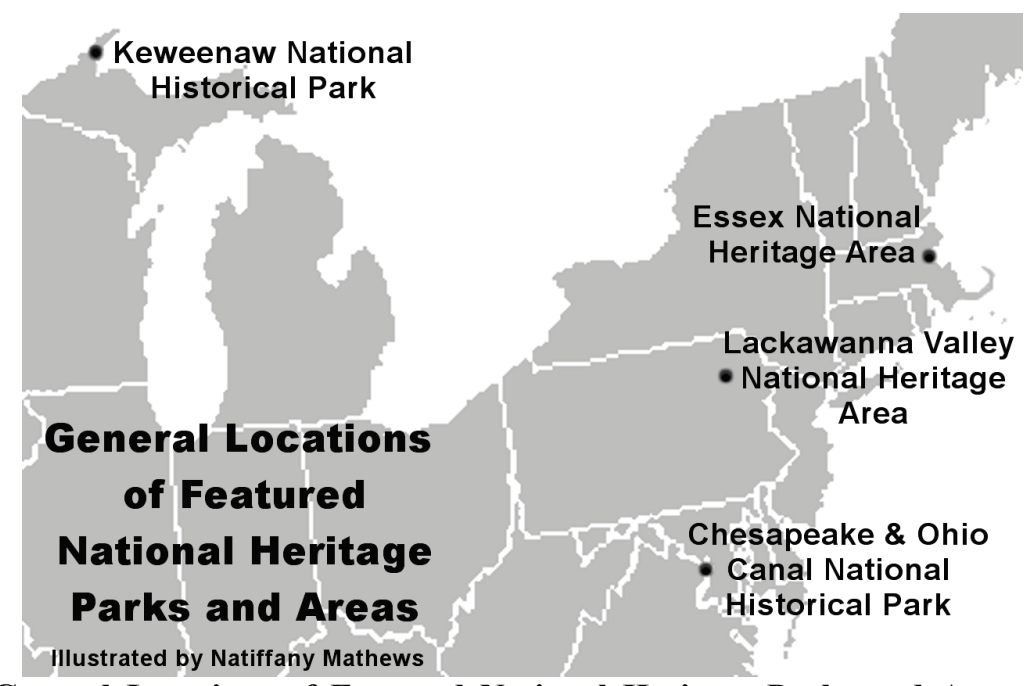

FIGURE 2.1: General Locations of Featured National Heritage Parks and Areas; located on the illustration are Keweenaw National Historical Park, Essex National Heritage Area, Lackawanna Valley National Heritage Area, and Chesapeake \& Ohio Canal National Historical Park (Illustration by the author based on USGS data).

(FIGURE 2.1). The park is essentially a long trail with campgrounds and historic structures peppered along its length. Visitors surveyed were primarily from Maryland, Virginia, and Washington D.C. Sixty-four percent of visitors came to C\&O Canal NHP as a primary destination; $55 \%$ of these visitors reported that they came primarily for recreational activities while $37 \%$ visited primarily to see the C\&O Canal NHP. The remainder of the survey focused on the economic impacts of visitors to the park. The authors concluded that while it appeared the economic impact was high, it was local visitors who were contributing to the economy. The authors also indicated that the park had value to local residents as a recreational and historical park (Stynes and Sun 2005).

The Essex National Heritage Area (ENHA) included sites of colonial, agricultural, and industrial historical significance and encompassed an enormous 500 square miles of eastern Massachusetts (FIGURE 2.1). In another survey by Stynes and Sun (2004a), much more information was requested from visitors than in previous studies. Essex was similar to Lackawanna because they were both heritage areas focused on history whereas C\&O Canal NHP is both an historic and recreational park. What they found were that "almost three in four" ENHA visitors held college degrees and "over 75\% have 
TABLE 2.1

COMPARISON OF FOUR HERITAGE SITE SURVEYS

\begin{tabular}{|c|c|c|c|c|}
\hline & $\begin{array}{l}\text { Bethlehem, } \\
\text { PA Visitors } \\
\text { Survey }\end{array}$ & $\begin{array}{c}\text { Essex NHA } \\
\text { Report }\end{array}$ & $\begin{array}{c}\text { Lackawanna Valley } \\
\text { NHA Report }\end{array}$ & $\begin{array}{l}\text { The Lowell } \\
\text { Experiment }\end{array}$ \\
\hline Ages 46 and up & $35 \%+{ }^{\mathrm{a}}$ & $75 \%$ & $79 \%$ & N/A \\
\hline Gender (M/F) & $\begin{array}{l}42 \% / \\
58 \%\end{array}$ & $\begin{array}{l}32 \% 1 \\
68 \%\end{array}$ & $\begin{array}{l}39 \% / \\
61 \%\end{array}$ & $\begin{array}{l}43 \% / \\
57 \%\end{array}$ \\
\hline Local Pop. & $64 \%$ & $29 \%$ & $62 \%$ & $12 \%^{\mathrm{b}}$ \\
\hline First Visit & N/A & $53 \%$ & $28 \%$ & $58 \%$ \\
\hline Media Sources & N/A & $\begin{array}{l}\text { Tourist Info: } 22 \% \\
\text { Newspaper: } 13 \%\end{array}$ & $\begin{array}{c}\text { Newspaper: } 28 \% \\
\text { Friends/Word of } \\
\text { Mouth: } 26 \%\end{array}$ & $\begin{array}{l}\text { Newspaper: } 7^{\mathrm{c}} \\
\text { Guide Book: } 4\end{array}$ \\
\hline
\end{tabular}

a: This percentage comes from those 50+ years old; those who were 30-49 were grouped separately

b. Percentage calculated from raw numbers of Lowell/Lowell Area responses

${ }^{c}$ : Actual number of responses; newspaper was the highest followed by guide book

household incomes above $\$ 50,000$ " which is, as the authors point out, characteristic of other heritage tourists (2004a:5). Three quarters of respondents were 46 years of age or older but only $29 \%$ of visitors were from Massachusetts (the surrounding area). Sixtyeight percent of visitors were female. ENHA demographics closely resembled those of Lackawanna in everything but visitor origin (TABLE 2.1). Ninety percent of respondents indicated that historical components were either the primary (45\%) or secondary (45\%) reason for making their trip to the ENHA but 50\% were not familiar with the ENHA at all before visiting (Stynes and Sun 2004a).

The Keweenaw National Historical Park (KNHP) interprets, preserves, and educates visitors on the history and experience of copper mining in the Keweenaw Peninsula of Michigan (FIGURE 2.1). The park works with local heritage sites in 
partnership. For their 2005 Visitors Study, the KNHP handed out 565 surveys to visitor groups at 12 of their 17 Cooperating Sites and received 403 of the questionnaires back (Le et al. 2005). From the demographics, 57\% of the park's visitors indicated their age between 36 and 70 and 55\% of respondents indicated that they resided in Michigan. With Wisconsin's border so near to the park, it was surprising that only $16 \%$ of the respondents visited from the state. When asked what their primary reason for visiting the area was, $32 \%$ responded with 'See natural resources/scenic beauty' and only 5\% responded with 'Learn about copper mining history' (Le et al. 2005).

A minority of the KNHP respondents indicated that they would like to see more signage and some expressed confusion on the lack of delineation of the park's boundaries. Overall, the visitors seemed satisfied with their visit and $86 \%$ stated that they now had a better understanding of the park's significance. When asked to rate the importance of certain features of the park, respondents overwhelmingly responded 'Extremely Important' or 'Very Important' to the attributes of 'Historic preservation', 'Historic landscapes/settings', and 'Historic buildings/features.' Though many visitors concerned themselves with natural beauty and scenery, they also found value in Keweenaw history (Le et al. 2005).

The purpose of the KNHP Visitors Study, however, was primarily economic, focused on how the park stimulated the local economy and how visitors found out about and navigated the park's ephemeral boundaries. Visitors were asked very general questions about their intentions in visiting the park and were not asked to detail exactly what they came away with from visiting the park. Collecting responses from both the Porcupine Mountains Wilderness State Park (18\% of respondents) and McLain State Park $(15 \%)$ may have skewed the results of the survey as visitors would not ordinarily go to these parks for their history (Le et al. 2005:3). While these two sites were cooperating partners with the KNHP, they were "nature" parks that focus upon outdoor activities and were not historical insofar as how most visitors interact with the sites. Analyzing the survey with those two "nature" parks separate from the rest of the responses might have presented a finer focus on how Keweenaw history was consumed by visitors.

Matthew Liesch studied the KNHP in a much different way: by "photo- 
elicitation" to study how members of the community of Calumet, Michigan perceived the boundaries of and valued the KNHP (2011:502-505). Liesch's informants were selfselected and categorized based on their economic class, assigned to them by Liesch through their line of work. The interviewees were divided between blue-collar and whitecollar citizens who had surprisingly different ways of viewing the park boundaries and the landscape of the park itself. White-collar respondents used words to describe the KNHP and the landscape that were more conceptual and positive whereas blue-collar respondents focused on derelict buildings and had sometimes negative descriptions of buildings in the park boundaries (Liesch 2011).

Economic class played a part in the next published work as well. In The Lowell Experiment (2006) visitor survey results and interviews, Cathy Stanton sought to understand how and why visitors valued the Lowell National Historical Park (LNHP). Stanton also investigated how the park and its employees fit into its surroundings, namely the town of Lowell which was post-industrial much like Calumet, Michigan. Stanton was also interested in local residents and their relationship to the LNHP, particularly their differing class perspectives. At the time Stanton wrote this book, Lowell was undergoing a "revitalization" that had been happening in stages since the founding of the National Park. The questions she asked reflected visitor impressions of that effort and of what the park set out to accomplish with its presentation of history to the public.

Stanton asked standard demographic questions in addition to that of ethnicity, something that she felt necessary because LNHP had made an effort to include information about ethnic diversity in their interpretations. Discussions of ethnicity also tied into economic class and labor issues, which were both prominent in the story of Lowell. One of the most striking findings related to visitors' disconnect from blue-collar work and their re-connection to it through Lowell, particularly the experiences of their parents, grandparents, and great-grandparents. A similar re-connection appeared to happen with the question of ethnicity. Stanton also contrasted her survey of visitors to her survey of park employees, finding the demographics and backgrounds strikingly similar (Stanton 2006).

Stanton's study featured many survey questions that assessed how visitors valued 
the park: if respondents had visited Lowell National Historical Park before, their reasons for visiting, and what they wanted to do at the park. Most importantly, Stanton asked respondents if they had a connection to industrial heritage and what values the preservation of industrial history had to respondents. These questions assessed the motivations and personal connections that drew visitors to historic sites.

Industrial and de-industrializing community members had mixed emotions about the vestiges left by what Anna Storm and other scholars called the "third industrial revolution'; that is, the changes in industrial development since about the 1970s (Storm 2008:15-6). Interviews and historical materials were used to document very specific yet similar stories of such de-industrialization using case studies at three unique places and landscapes from Sweden, Germany, and the United Kingdom. In those three different places, Storm saw a transformation from the despair of lost industry into, "hope and belief in the future," which was symbolized in the reuse of industrial complexes and subsequent revitalization of struggling communities (2008:165). These places were related through industry yet composed of unique circumstances that led to their rehabilitation and local involvement in that rehabilitation. Visitors to these areas played a large role in their rehabilitation but Storm chose to focus instead on the communities conducting the recovery. Storm found that there was meaningfulness and strong emotion tied to revitalization for those involved in it but there was little investigation into how people not associated with revitalization felt, such as the working classes (2008).

In their paper, "A Visitors' Evaluation Index for a Visit to an Archaeological Site," Martin-Ruiz et al. proposed a Visitors' Evaluation Index (VEI) which evaluated the qualities that visitors desired in their experience at an archaeological site. This index used four categories for evaluation: 'service quality', 'service experience', 'service convenience', and 'visitor's satisfaction'. The authors used Italica, a Roman archaeological site in Spain, for their first case study of this index. Utilizing Structural Equation Modeling (SEM), the category which the authors found to be the largest contributor to VEI was 'service experience' which was the "subjective personal feeling experienced by visitors as they consumed the service" (Martin-Ruiz et al. 2009). Thus the authors concluded that in order to create a better experience for site visitors, 'service 
experience' should be the focus of visitation improvement efforts.

A recent opinion survey was undertaken by English Heritage, a non-departmental public body of the British Government that oversees preservation of the built environment, and was published in the fall of 2011. This survey, entitled "Industrial Heritage at Risk: Public Attitudes Survey," contained an exhausting amount of information gathered from 2,000 survey respondents in different regions of England. This survey provided insight into if, where, and why industrial heritage was valued throughout England. Responses indicating how industrial heritage was valued were categorized into Identity, Economic, and Other. Many respondents felt that their local non-preserved industrial structures brought down property values, but more importantly, they held significant personal value.

Respondents had many positive things to say about the structures, overwhelmingly stating that industrial structures gave them a pride in their area and held family heritage. The structures also inspired nationalistic feelings and were considered important reminders of industrial progress, a sometimes painful but often nostalgic idealization of the past. The survey report included a section in which the degree to which the public wanted to be involved was gauged rather than assumed. Overall, $86 \%$ of surveyed adults felt that valuing the industrial heritage of England was important (English Heritage 2011).

\section{Synthesis}

Each of the preceding pieces of literature contributed significantly to the formation of not only the opinion survey questions administered at the Cliff Mine field school but also to the semi-structured interview questions asked of selected survey participants and local experts. The literature also indicated areas of needed improvement in surveying and interviewing the public within the broad disciplines of heritage studies and historical archaeology. This discussion summarizes the most compelling connections between the Cliff Mine study and this body of literature.

Parker B. Potter used a single-question survey on the Shiplap House tours in Archaeology in Annapolis. A different approach was taken with the Cliff Mine tour 
survey. Even though the participant groups in both studies were likely to attend because of their interests in history and archaeology, what the public had to express at in Cliff Mine tour survey were their own values and perspectives. The only way to know what people are specifically taking from their experience at the Cliff Mine public tours is to go beyond what they learned about archaeology specifically and to ask about heritage and preservation, as well as how they feel about the tour itself.

Potter added two questions for his later Main Street Annapolis tour; however, his results were as mixed as his visitors. A readily accessible tour attracted more than just the historically and archaeologically-inclined as he found out through analyzing the survey results. Based on oral accounts of the Cliff Mine 2010 site tour, visitors came armed with general knowledge of the site that the tour guides attempted to elaborate on. The Cliff Mine tour was not as accessible and has not attracted many people disinterested in history or archaeology. Participants offered their own accounts of the history of the Cliff and of interacting with the site. This means Cliff Mine visitors are an engaged and self-selected group of tour-goers quite unlike Potter's group on the Main Street Annapolis tour.

Cameron's study of Bethlehem, Pennsylvania told of similar adversity to the Copper Country, adversity which struck much earlier in the 20th century. Though much earlier than the hypothesized 'third industrial revolution,' (Storm 2008:15-6) many parallels can be drawn between what happened in the Keweenaw Peninsula and in the Rust Belt, particularly because of the ways communities responded to, and continued to cope with, the de-industrialization process. This process emerges in the landscape of industrial heritage and the preservation or decay of landmarks representing it, such as the Cliff Mine and industrial sectors of Bethlehem. Cameron and Gatewood's work in Bethlehem was also paralleled in the Cliff Mine tour survey through the way both engaged visitors and collected perspectives local people held about heritage.

McDavid's website in "Archaeologies That Hurt; Descendants That Matter" utilized an online survey but her paper was primarily useful for understanding the motivations for creating dialogue between archaeologists and community members. The Cliff Mine survey was created with similar aims to McDavid's website, but as a static recording of feedback and dialogue with community members and visitors. 
To cement their supposition that all three parks (Canal and Ohio, Essex, and Lackawanna) held value because of their historical and recreational nature, Stynes and Sun could have re-surveyed or included several questions about the relationship visitors had to each of the parks. This was not the primary aim of Stynes and Sun's survey, particularly because these reports was prepared in conjunction with the NPS, but focusing solely on economics without understanding park visitorship on a deeper level was too narrow a focus to analyze such a complex issue. Probing the impressions, motivations, and values that visitors have when they visit historic, and in particular, industrial sites might provide valuable insight that could be used to support NPS economic studies. The Cliff Mine tour survey seeks to explore these areas of visitor experience in depth, as both an industrial heritage site and as a local recreational destination.

Demographic similarities and differences between Cliff Mine tour visitors and park visitors in the three Stynes and Sun surveys will be drawn in Chapters Four and Six. A problem with the Stynes and Sun surveys is that they failed to measure the importance of such sites to visitors as well as the connections or personal value they held to individuals. In these surveys, visitors were relegated to simply being consumers of a product in measures such as 'consumer spending' indices. Economic factors are very important to keeping historical sites in funding and support but they are not enough to create a holistic analysis.

Stanton's interviews and surveys laid a foundation with which to build this project and have influenced its inception. Questions about what visitors do at the Cliff Mine when they visit and about the importance of preservation and heritage feature strongly on the Cliff Mine tour survey as they did in Cathy Stanton's survey of Lowell. The Cliff Mine tour survey asked these questions but the Cliff Mine is not a park so the relationship between the survey and respondent was not tied to an institution such as the NPS but to a site with blurred boundaries. In contrast to Stanton's motivations, the Cliff Mine tour survey will not ask respondents to divulge either income or ethnicity.

Anna Storm's work Hope and Rust used semi-structured interview methods to explore the community of areas which underwent a 'third industrial revolution' and deindustrialized around the 1970s. The Cliff Mine is a part of a community that experienced 
this process much earlier. Storm explored how the industrial past offers meaningfulness and revitalization of places charged with emotion. Such emotional connections to place were found in Cameron and Gatewood's survey and termed numen (2000:118). The Keweenaw has its share of such places, like the Cliff Mine, with people from outside the community "turning the partly problematic industrial past into a tourism commodity," but the consumers of tourism are still not completely understood (Storm 2008:116). Connections to place and tourist experiences will be gauged from the collected survey and interview data to enrich what is already known about industrial heritage visitors.

Understanding visitor experiences can only be done through surveying and interviewing them. Visitors' emotional experiences at archaeological sites (or connections to these sites, in the case of the Cliff Mine) are highly important and color much of their overall evaluations of those sites. Several questions in the Cliff Mine survey and participant interviews address emotional connections to the site to understand the visitor's motivation to attend. My intentions, however, were different than those of the study by Martin-Ruiz et al. (2009) who sought to gauge visitor experience through the lens of tourism. The Cliff Mine tour survey goes further in its assessment of, not only visitor satisfaction, but outreach effectiveness and value from the perspective of a heritage professional. The intentions of the survey research at the Cliff Mine were less about improving tourism-based experiences and more about improving relations between the community and preservation efforts while also understanding the public's attitudes toward the preservation of the Cliff for both heritage and tourism.

English Heritage's "Industrial Heritage at Risk" survey was the work of the most relevance to the questions asked of the Cliff Mine participants. The English Heritage survey aimed to understand how English citizens in industrial areas valued the industrial heritage around them and why. Governmental organizations such as English Heritage, much like the NPS in the United States, are limited in their ability to preserve due to limited funding so must choose their targets wisely. The Cliff Mine survey and interviews asked participants about the value of preservation and industrial heritage in a similar effort to understand public valuation of industrial heritage and to foster support for its preservation. The main differences were that the setting of the Keweenaw Peninsula is a 
micro-setting instead of the macro-setting of England and English Heritage sought to find the most-valued and worthwhile sites to preserve all over England. Only select sites can be preserved at any given time so knowing which sites the public values and visits is an important component in fostering support for such preservation.

Knowing how communities and visitors value heritage and conceptualize archaeology is key to understanding how to tailor outreach to be more effective and positively impact communities. We know that people are interested in archaeology in general (Ramos and Duganne 2000), but historical and particularly industrial archaeology might be less recognized in the United States than prehistoric archaeology. Industrial and historical archaeologists should understand those public perceptions in order to know how to reach out to a public that may be largely indifferent to, or ignorant of, our specialized professions and threatened sites.

An important component of public outreach is the ability to gather input from the public, particularly because public support is necessary to maintaining and creating programs for preservation and excavation. This involves using applied anthropology and ethnographic methods, such as qualitative surveys and interviews, to understand the specific cultural milieu of the time, in the area of study. The United States is a largely post-industrial society that has been unhappy about its loss in the area of industry and subsequent transition into a service economy (High and Lewis 2006:8-13). Destroying industrial structures is often viewed as a way to push forward, but unfortunately, 'local' people are often left feeling powerless about their future and disenfranchised from their past (High and Lewis 2006:23-39).

Like English Heritage has done with their recent survey of England, historical and industrial archaeologists and all heritage professionals must understand what the public values in order to create a sustainable and realistic preservation strategy suitable for their specific area and time. We must also take Merriman's 'multiple perspective model' seriously and seek to enrich and add to culture and quality of life for the people we work with (Merriman 2004:6-8). Crafting an appropriate metric to measure public perspectives and values in a particular area, as well as planning an analysis of the collected data, are the logical next steps in acquiring this information. 


\section{CHAPTER THREE METHODS}

Multiple data collection methods were used: an on-site survey, semi-structured interviews, and focused interviews with local experts. The survey questions were the primary method of gathering information on visitor perceptions of local heritage, how visitors valued the Cliff Mine and industrial history, and what visitors expected from the archaeological tour. Semi-structured interviews with tour participants were conducted to expand on and add to interviewee answers from the survey. Finally, focused interviews with local experts contributed perspectives on heritage and preservation from professionals in the Keweenaw area.

\section{Planning the Survey}

Several qualitative survey manuals assisted in the process of designing the survey and the survey questions (Fink 1995; Fink and Kosecoff 1998; Groves et al. 2009; Schutt 2009). The questions formed around standard guidelines: keeping survey objectives in mind for each question, creating a simple but effective aesthetic, crafting clear and concise questions, and avoiding errors in language such as double-negatives (Fink 1995:6-9; Fink and Kosecoff 1998:9-11, 30; Groves et al. 2009:227-229; Schutt 2009:262-263). By testing the survey on preliminary participants, which is an "essential step" in survey research, the less successful questions were eliminated or refined (Schutt 2009:275). A large number of open-ended questions were planned because of the setting and the projected participants ${ }^{1}$.

The pre-survey and post-survey design was an experiment to find evidence of change in respondent awareness and opinion. Each survey packet had one pre-tour survey, one posttour survey, and a release form. Respondents were instructed to take the pre-tour survey and then to place their survey in a folder. On their way to the exit, they could then retrieve their surveys and fill out the remaining two pages. The full survey took approximately 30-45 minutes to complete.

\footnotetext{
${ }^{1}$ The lead archaeologist and professors who supervised the Cliff Mine tour in 2010 indicated that participants were eager to share their experiences and opinions with the tour guides and students, influencing survey length.
} 


TABLE 3.1
\begin{tabular}{|c|c|c|c|}
\hline VISITOR NUMBERS AND SURVEY COMPLETION DATA \\
\hline $\begin{array}{c}\text { Total } \\
\text { Visitors }\end{array}$ & Incomplete Surveys & Completed Surveys & Total Tour Days \\
\hline \hline $400>^{\mathrm{a}}$ & 21 & 116 & 5 \\
\hline
\end{tabular}

a: Minors not counted; some groups may not have been completely counted.

\section{Recruiting Participants}

To advertise the 2011 Cliff Mine field school tour, a sign was placed on the roadway facing the north end of Cliff Drive as this would be the shortest route to the site. Passersby who knew of the tour in advance would know to stop near the sign and park (FIGURE 3.1). Passing motorists could quickly read the sign and understand what was happening. Press releases were printed by the MTU campus newspaper (online and in print) as well as by the Mining Gazette, the local newspaper. The first article was published two weeks before the field school ended ${ }^{2}$ and the second article was published on the day before our last tour weekend. During the fifth week of field school, the local television news aired a story about the field $\operatorname{school}^{3}$.

The press release had the location and times for the tour listed as well as suggestions on what type of clothing to wear, warnings on the rugged terrain, and the inability to accommodate disabled persons. Dr. Scarlett placed flyers at different places around Keweenaw and Houghton Counties. Several local event calendars and websites carried information about the tour ${ }^{4}$. Dr. Scarlett notified contacts at the Keweenaw County Historical Society (KCHS) of the tours and the organization spread word through their constituents. Dr. Scarlett also sent the press release about the Cliff Mine tours to local radio stations that made announcements during their local events segments

\footnotetext{
2 Article found at: http://www.mininggazette.com/page/content.detail/id/520759/Tech-team-turfs-up-treasures-at-CliffMine.html in the 17 June 2011 issue of the Mining Gazette.

3 Article found at: http://www.uppermichiganssource.com/news/story.aspx?id=630269

${ }^{4}$ The local websites contacted include: http://www.keweenawhistory.org/calendar.html; http://www.keweenawheritagesites.org/; http://keweenawfreeguide.com/; http://www.keweenaw.info/calendar.aspx; http://www.coppercountryexplorer.com/
} 
throughout a three week period.

\section{Tour and Survey Environment}

It was intended that the tours would be given on the hour and that tour visitors would arrive in groups of no more than 30 visitors. This estimate was based on the previous year and adjusted for the addition of the excavation. Unexpectedly, over 400 visitors arrived in the course of three weekends or five tour days (TABLE 3.1). The selfselected survey participants returned 116 complete surveys and 21 incomplete surveys. Complete surveys had a full demographic profile and at least some qualitative questions answered. Incomplete surveys had few to none demographic questions answered and few to none qualitative questions answered.

The environment of the Cliff Mine is situated on the west fork of the Eagle River near a large basalt cliff and almost completely covered in birch and coniferous trees. Near the fork of the Eagle River are shrubs and stamp sands which can be flooded during times of heavy rain. Long pieces of lumber acted as small bridges to get visitors across the river and to the Cliff Mine area. Large mounds of poor rock slightly obscure the forested area of the Cliff Mine building foundations. It was a confusing area for many visitors who were navigated through it by students, Dr. Scarlett, and the author.

The survey was conducted on-site at a welcoming table where the author greeted people (FIGURE 3.1). Visitors were provided with historical photos to assist in guiding the tour and visualizing the site. The Cliff Mine tour lasted about an hour. The participants were given a brief history of the Cliff Mine and the site in general, and then the tour group trekked past Cliff Mine-era foundations, following the flow of worked ore from mine shaft to stamp mill, and headed toward the excavation. Some tours were so large that the tour guide, Dr. Scarlett, was forced to shout so that groups of over 40 people could hear. After the walking tour, visitors explored the site or returned the way they came. The only exit was to walk past the welcoming table where participants filled out the post-tour survey before leaving.

Due to the voluntary, anonymous nature of the survey and the time constraints of the tour, participants were only asked once if they would fill out the survey. Rather than 


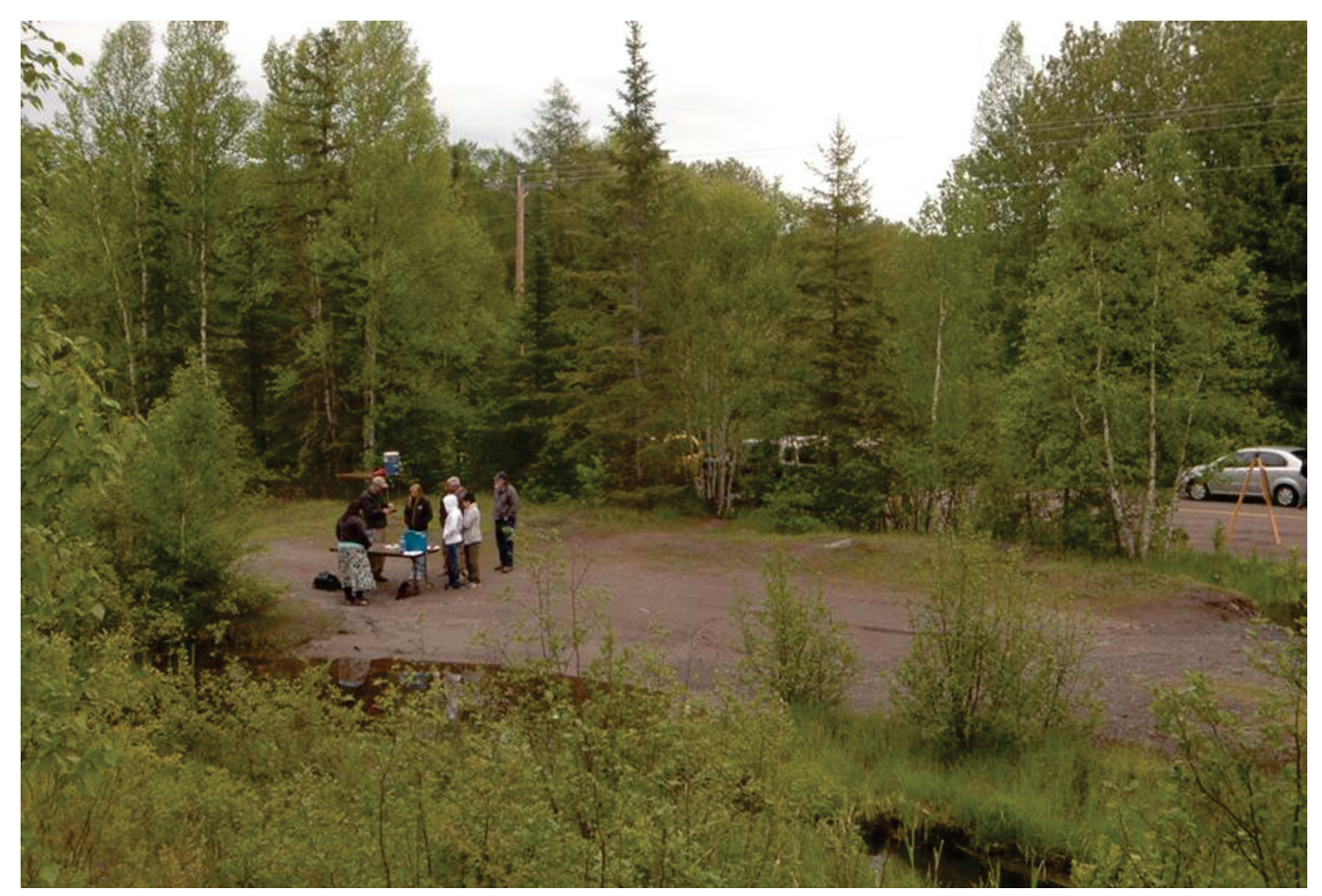

FIGURE 3.1: In this photograph, the author and Dr. Scarlett greeted visitors to the Cliff Mine field school tour. The west fork of the Eagle River is located at the bottom of the photograph. Cliff Drive is in the middle where cars are parked. The sign placed along Cliff Drive can be seen in the middle right of the photo (Photograph courtesy of Mark Dice).

being confrontational by approaching visitors with the survey in hand, participants were asked if they would volunteer their opinions in the survey. This approach allowed participants to freely approach the table and pick up surveys without feeling pressured to do so. Subsequently, the sample consisted of whoever volunteered and successfully completed at least one full page of the survey. Those who took the survey either leaned on provided tables or stood with a clipboard to complete them.

\section{Testing the Survey}

The first day of public tours at the Cliff Mine was a time for 'pilot testing' or 'pretesting' the survey instrument, a standard practice to increase productive survey responses and to eliminate problems like non-response and confusing language (Fink and Kosecoff 1998:35-36; Groves et al 2009:265-267). Russell K. Schutt also recommends restricting 
questions to, "20 words or fewer and the number of commas to 3 or less," unless the question requires a longer length to retain clarity (Schutt 2009:262). As the test group matched the intended respondents for the survey and was a relatively small group, the visitors from the first day of conducting tours were ideal for pilot testing (Groves et al. 2009:265-266) ${ }^{5}$.

Twenty-nine people arrived on the first day of public tours at the Cliff Mine. From the 14 finished test surveys, feedback received indicated that the font should be bigger to aid in reading the survey outside. Two questions from the demographics section were removed; "How long have you considered yourself to be local?" and, "Do you still live in the U.P.?" While these two questions were answered by all of the 'local' respondents, feedback on-site indicated that both of these questions were either difficult to answer or caused respondents confusion. Identifying and removing confusing or problematic questions was an important function of the pretest (Groves 2009:265).

The question, "Do you use the Cliff site for any activities?" was changed to standardize responses. Ten options were added for participants to circle, including an 'Other' category. Several survey questions were ignored or skipped over by the test respondents, such as "Do you feel your activities at the Cliff site are challenged by others?" Asking this question elicited negativity and confusion according to several test respondents so it was removed (Schutt 2009:263). The question also fell outside of the intended focus of the survey (Schutt 2009:278).

The question, "How important is copper mining to the heritage of the Keweenaw and why?" was removed after the pilot test. Most people who filled out the test survey were emphatic about the importance of copper mining heritage and it became obvious that this question would not provide unique data. Some of the complex or unanswered questions were kept because of the potential they had to provide unique data. The survey was trimmed to only the questions which were deemed important to keep for the purpose of answering the research questions.

Three questions were repeated on both the pre- and post-tour survey. In the pilot test, the second round of these questions had many non-responses. A line of text

\footnotetext{
5 This test group acted both as a focus group and test group; both qualitative data and on-site feedback were used to improve the survey.
} 
indicating that the three questions were repeats was removed and the questions were reworded. Testing the survey on actual visitors assisted the development of the final survey and fulfilled a necessary requirement of survey research (Fink and Kosecoff 1998:33).

\section{Demographic Questions}

Several standard demographic questions (age, gender, occupation, etc.) were placed at the beginning of the pre-tour survey. Demographic information was used in identifying the groups interested in industrial heritage and history and comparing these groups to those of other heritage surveys. Standard demographics also assisted in identifying similarities between the Cliff Mine tour participants and visitors to heritage sites around the United States. Later in the pre-tour survey, respondents were asked how they learned about the Cliff Mine tour. The remaining five demographic questions were specific to the Cliff Mine tour. Full demographic questions can be found on the Pre-Tour survey in Appendix A.

The first specific demographic question asked if the respondent had visited the Cliff Mine tour in 2010. The tour in 2010 did not involve an excavation as it was primarily a mapping survey to find features for future excavation. Responses to this question should reveal the respondent's interest in the Cliff Mine and a continued observation of the MTU Social Science department's activities.

Next, respondents were asked, "What geographic area do you reside in currently?" The purpose behind such an open question was to reassure the respondent that the surveyor does not want to know enough information to identify them and that the surveyor would only like a general response that was at their comfort level. This question helped to identify where part-time residents and visitors were traveling from.

Respondents were then asked, "Which describes your residency best?" Ascertaining whether or not a participant lives in the area year-round or otherwise was important when looking at their geographic residency. It can also partially explain why a respondent might never have been to the Cliff Mine area, why they list primarily tourist destinations further on in the survey, or how the respondent feels about local history and 
preservation.

In an effort to understand how people ascribe certain values to themselves, the next question asked, "Do you consider yourself local to the U.P. or non-local?" Detailed investigation into this question featured prominently in the later semi-structured interviews to support survey data. The expectation was that visitors to the Cliff Mine site have extremely variable ideas as to what was 'local' or not. It may become clearer what their conception of 'local' really was when compared with the respondent's area of residence and residency, and even occupation.

The final demographic question was, "What activities do you enjoy at the Cliff Mine or Clifton sites?" The selections that could be circled were: Hiking, Rock Collecting, Snowmobiling, ATV, Snowshoeing, Exploring, Other Collecting, Photography, Nothing, and Other. Inserting 'Other Collecting' here was a way of trying to gauge how many participants may be collecting artifacts from the site ${ }^{6}$. Through selecting 'Other Collecting,' the participant may be innocently admitting to collecting or may be insinuating they collect natural items such as leaves or kindling.

The main purpose of asking demographic questions was to make a general conclusion about the characteristics of those who participated in the 2011 Cliff Mine tour. In addition, demographics serve as a point of comparison and contrast to other studies.

\section{Qualitative Questions}

Asking qualitative questions was the underlying motivation for collecting survey data at the 2011 Cliff Mine field school tour. These questions examined visitor values, perspectives, and expectations in order to improve public outreach methods in archaeology and heritage management. Qualitative data also indicated the levels of support for industrial heritage and how it was valued by visitors to the Cliff Mine. The full Pre- and Post-Tour surveys are located in Appendices A and B.

Pre-tour questions asked participants about prior tour and heritage site visitation, archaeological experience, and whether or not the participant was a member of a heritage or archaeology club. These questions ascertain how familiar the participant was with

${ }^{6}$ Artifact collection is legal at the Cliff Mine property as of 2012. 
archaeology and the history of the Copper Country. They also indicate how active the participant was in their community and what degree of importance the participant places on heritage, history, and archaeology. The answer to this question may indicate why people become involved in industrial archaeology and heritage in the Keweenaw.

In order to draw a personal link between an interest in heritage and an interest in either the Cliff Mine or industrial history, I asked "Have you or a relative/ancestor worked in mining/mining-related industries? Does this relate to your interest in the Cliff site?" The answers may reveal connections between the exploration of Keweenaw heritage sites and identity. This question also primes the participant to think about the meaningfulness of the Cliff Mine in the overall story of mining heritage.

The pre- and post-tour surveys both had corresponding sets of questions which were meant to be compared. The pre- and post-tour survey format was created specifically to experiment with questions that were repeated to gauge changes in visitor perspectives. Making improvements to and understanding the impact of the tour may be achieved through using these before and after questions. They have the ability to lead to an understanding of a visitor's expectations and experiences, positive and negative, on the tour.

Three questions and a follow-up were created for both the pre- and post-tour surveys. The first two questions on the pre-tour survey asked the participant to declare whether or not touring and participation at heritage sites was important and whether or not preserving such sites should be a priority or not. These questions were created to assess the value that participants place on experiencing archaeology and heritage tours as well as how they value local heritage preservation.

The third question on both the pre- and post-tour survey asked, "Should there be more opportunities for participating in archaeology and heritage events in the Keweenaw?" with a follow up that asked the respondent where and what they would like to do at heritage sites. Again these questions asked respondents about their values, specifically if they valued touring heritage sites and wanted to engage in heritage and archaeology events. Asking respondents where they would like to do activities and attend events not only identifies sites where interpretation and public engagement are desired, 
but also, as in earlier questions, assesses the respondent's familiarity with local heritage sites.

The last of the pre-tour questions was, "What do you expect to see or to learn about on your tour today?" The focus of this question was what the visitors' expectations prior to the tour were. Knowing visitor expectations was important to understanding outreach effectiveness.

The post-tour survey asked, "Would you participate in a tour of an archaeological site again? Why or why not?" This question was then followed by asking if the tour could have been improved. Both of these questions gave the respondent a chance to identify both their enjoyment and/or disappointment with the tour. Two more questions asked the visitor if they were satisfied with the communication between crew members and the tour groups on-site. Such questions addressed the level of shared information and interaction given by the tour guides and students in addition to following up on the visitor's expectations.

A more direct approach was taken with the next question: "From your experience on the tour, do you think the archaeologists do a good job of incorporating people into projects like the Cliff? Why?" Participants were asked to state an opinion based on the way the site archaeologists involved the tour groups into discourse and the project. The wording here of 'people' instead of 'public' and 'the archaeologists' instead of 'archaeologists' was intentional. The word 'public' was too specific (and loaded with bias) at a tour that was open to everyone. The idea of a public can be confusing and alienating as well. Additionally, simply stating 'archaeologists' was too general when an assessment of 'the archaeologists' as a group was necessary for the research.

Several questions asked the participants what other subjects they would enjoy seeing explored and what heritage activities they would like to do. These questions asked the respondents to look to the future. If they are able to participate in activities they enjoy, it is more likely that they will continue to visit heritage sites. Visitor interests, again, are important outcomes of the qualitative questions. Furthermore, the qualitative questions also point to the respondent's desire to seek out new industrial heritage experiences or to return to the Cliff Mine site in the future. In addition, the respondent's main interests at 
heritage sites in general can be surmised from their answers.

\section{Coding}

Coding is a process of separating raw data into thematic groups. These groups are formed through an initial interpretation of the data and are alternately grouped generally and specifically based on the intent of the researcher. Coding the data for this project began as soon as the survey data were transcribed into Microsoft Excel. The demographic questions were separated from the qualitative questions. Demographic data were coded in the program SPSS to make comparative charts and graphs for interpretation. Qualitative data were entered in a Microsoft Excel database and organized into categories. Each answer has its own set of categories which it could belong to. These categories were based on the specificity of responses and their themes. For example, the category 'Specific Activity' was created when a respondent answered a question about what they would like to do at heritage sites. Some answers were vague or enigmatic and were not analyzed further.

\section{Interviews}

Survey respondents had the option of providing contact information for future interviews. The selection of interviewees was based on demographic status, such as age and gender, and when possible, representatives of demographic categories such as residence. Interviewees were contacted through email and telephone and were asked to take part in a 30-minute interview. Many of the respondents who were contacted for an interview never responded, making the goal of interviewing some demographic groups more difficult than others. A total of seven site visitors agreed to interviews.

The questions for Cliff Mine survey respondents' follow-up interviews were based on the survey data. Interviewing began 3-5 months after the field school ended. The process of interviewing survey respondents involved re-acquainting the interviewee with their experiences at the Cliff Mine during their 2011 tour. Once they had started to remember their experience in months prior, significant questions could then be asked about how the Cliff Mine tour impacted their views on archaeology and preservation. 
Interviewees were also asked about their choice in identifying as either local or non-local visitors during their interview.

In addition to survey participants, nine local experts were interviewed regarding historic preservation, Keweenaw tourism, mineral collecting, and the interpretation and preservation of the Cliff Mine. Experts in various fields related to heritage and tourism were chosen through local contacts and members of the Social Sciences department at MTU. Interviews were conducted both face-to-face and over the telephone. The exclusion of interview data from survey data was intentional because, as a supplement, it has its own manner of being analyzed and interpreted. Interview data were classified into coded groups organized by question as well as the category of the interviewee (either survey respondent or local expert). Survey respondents and local experts were interviewed and categorized separately because of their differing experiences and perspectives. Interviewee demographic profiles are listed in Appendix C. 


\section{CHAPTER FOUR SURVEY RESULTS AND DISCUSSION}

After constructing and testing the survey instrument, the final version of the survey was administered. The Cliff Mine tour visitor survey document had three components: demographics, a qualitative pre-tour survey, and a post-tour survey. Data analysis began soon after the collection of the surveys ended. Demographics were handled by the statistics software SPSS and a Cliff Mine tour visitor profile emerged. Demographic categories included age, gender, occupation, location, residency, locality, and activities enjoyed at the Cliff Mine site.

Qualitative data came from both pre-tour and post-tour survey questions. These questions elicited data which were then categorized by how the respondent answered; for example, the category Yes, positive comment included direct answers such as, "Yes, the tour was fun," and "Yes, I enjoyed myself." Responses were distilled down into generalized response groups.

After presenting the data, I offer conclusions about the effectiveness of the survey design. Of concern are the overall pre- and post-tour design and how the responses differed between the two surveys. Finally, a complete analysis of all of the collected survey data is discussed to understand visitor expectations and the results of the Cliff Mine tour outreach efforts. The full transcription of survey questions can be found in Appendix A.

\section{Demographics}

The demographic section of the survey was the simplest way to identify general visitor groups to the Cliff Mine field school tour. The ages, genders, occupations, geographic, and local identities of Cliff Mine tour visitors are important for establishing a comparison to other industrial heritage site visitors. In addition, the demographics illustrate the categories of community members and tourists who attended the tours. Visitors were also self-selected; it took effort to reach the Cliff Mine tours so a predisposition toward industrial heritage site tourism was assumed. 
TABLE 4.1

FREQUENCY TABLE REPRESENTING RESPONSES FOR AGE

\begin{tabular}{|rl|r|r|}
\hline & Frequency & Percent \\
\hline \hline Valid & $56-65$ & 37 & 26 \\
& No Answer & 27 & 19 \\
$66-75$ & 25 & 18 \\
$46-55$ & 20 & 14 \\
$18-25$ & 13 & 9 \\
$26-35$ & 9 & 6 \\
$36-45$ & 7 & 5 \\
$76-85+$ & 4 & 3 \\
Total & $\mathbf{1 4 2}$ & $\mathbf{1 0 0}$ \\
\hline
\end{tabular}

$\underline{\text { Age }}$

The most represented group in the age demographic was the 56-65 age group with $26 \%$ of respondents (TABLE 4.1). Following this group were non-responses with $19 \%$, $66-75$ with $18 \%$, and $46-55$ with $14 \%$. The remaining age groups were $18-25$ (9\%), 26-35 $(6 \%), 36-45(5 \%)$, and $76-85$ or older $(3 \%)$.

\section{$\underline{\text { Gender }}$}

In the demographic category of gender, $44 \%$ of respondents were male and $38 \%$ were female (TABLE 4.2). In some age groups (18-25 and 56-65), men outnumbered women 2:1 (FIGURE 4.1). Eighteen percent did not answer at all. Many of the non-responses in this demographic also had non-responses in the Age category.

TABLE 4.2

FREQUENCY TABLE REPRESENTING RESPONSES FOR GENDER

\begin{tabular}{|cl|r|r|}
\hline & Frequency & \multicolumn{1}{|c|}{ Percent } \\
\hline \hline Valid & Male & 62 & 44 \\
& Female & 54 & 38 \\
& No Answer & 26 & 18 \\
& Total & $\mathbf{1 4 2}$ & $\mathbf{1 0 0}$ \\
\hline
\end{tabular}




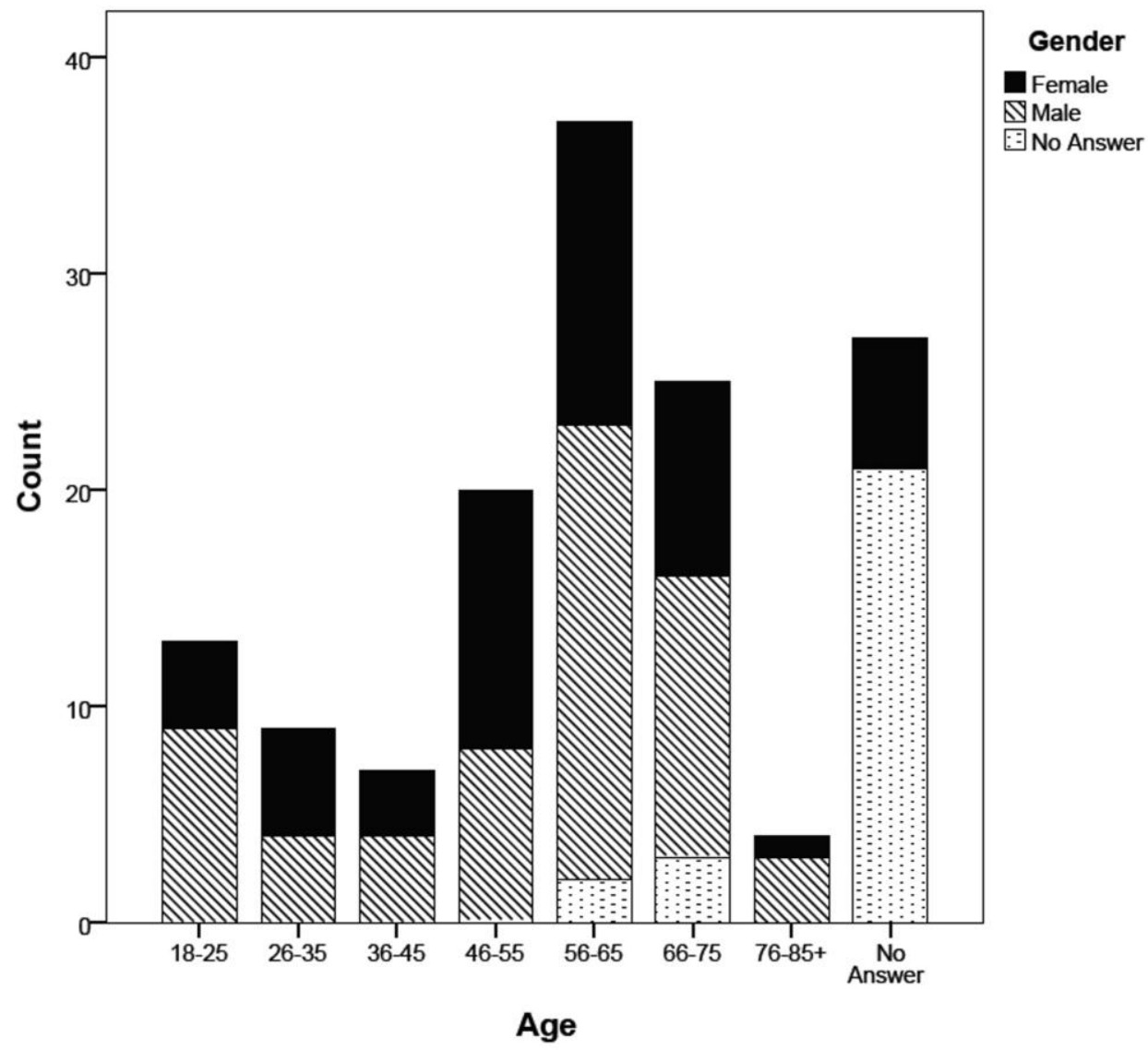

FIGURE 4.1: Age groups of respondents categorized by Gender (Graph created by the author with SPSS).

\section{Occupation}

A wide variety of occupations was represented by the responses to the occupation demographic (TABLE 4.3). Non-responses numbered 35\%. Retired persons (22\%) and educators $(8 \%)$ dominated the responses. The third most reported occupation was student with $4 \%$ of responses followed by engineer (4\%), small business owner (3\%), medical field (3\%), unemployed (2\%), and mechanic (2\%). The remaining occupations had 2 or fewer responses. White-collar occupations outnumbered blue-collar by a ratio of $4: 1$. This difference was found by separating occupations into those which required a college degree (white-collar) and those that did not (blue-collar). 
TABLE 4.3

FREQUENCY TABLE REPRESENTING RESPONSES FOR OCCUPATION

\begin{tabular}{|c|c|c|c|}
\hline & & Frequency & Percent \\
\hline \multirow[t]{28}{*}{ Valid } & No Answer & 49 & 35 \\
\hline & Retired & 31 & 22 \\
\hline & Educator & 11 & 8 \\
\hline & Student & 6 & 4 \\
\hline & Engineer & 5 & 3 \\
\hline & Medical & 4 & 3 \\
\hline & Small Business Owner & 4 & 3 \\
\hline & Mechanic & 3 & 2 \\
\hline & Unemployed & 3 & 2 \\
\hline & Accounting & 2 & 1 \\
\hline & Arts & 2 & 1 \\
\hline & Clerical & 2 & 1 \\
\hline & Government & 2 & 1 \\
\hline & Homemaker & 2 & 1 \\
\hline & Researcher & 2 & 1 \\
\hline & Social Worker & 2 & 1 \\
\hline & University & 2 & 1 \\
\hline & Athletics & 1 & 1 \\
\hline & Counselor & 1 & 1 \\
\hline & Custodian & 1 & 1 \\
\hline & Historian & 1 & 1 \\
\hline & Industrial & 1 & 1 \\
\hline & Intern & 1 & 1 \\
\hline & Landscaper & 1 & 1 \\
\hline & Massage Therapist & 1 & 1 \\
\hline & Photographer & 1 & 1 \\
\hline & Sales & 1 & 1 \\
\hline & Total & 142 & 100 \\
\hline
\end{tabular}

\section{Geographic Area}

Participants were also asked to identify the geographic area they currently live in. Houghton County represented $42 \%$ of respondents and Keweenaw County $23 \%$, meaning the majority of survey respondents live in the Keweenaw Peninsula (TABLE 4.4). 'No Answer' accounted for $21 \%$ of collected responses. Other states (including the Lower Peninsula of Michigan) represented $9 \%$ of respondents with the remainder from elsewhere in the Upper Peninsula of Michigan, including Baraga County (6\% total). 
TABLE 4.4

FREQUENCY TABLE REPRESENTING RESPONSES FOR GEOGRAPHIC AREA

\begin{tabular}{|c|c|c|c|}
\hline & & Frequency & Percent \\
\hline \multirow[t]{12}{*}{ Valid } & Houghton County & 59 & 41 \\
\hline & Keweenaw County & 32 & 23 \\
\hline & No Answer & 30 & 21 \\
\hline & Upper Peninsula & 7 & 5 \\
\hline & Lower Michigan & 4 & 3 \\
\hline & Wisconsin & 3 & 2 \\
\hline & Baraga County & 2 & 1 \\
\hline & Illinois & 2 & 1 \\
\hline & Iowa & 1 & 1 \\
\hline & Midwest & 1 & 1 \\
\hline & Tennessee & 1 & 1 \\
\hline & Total & 142 & 100 \\
\hline
\end{tabular}

\section{$\underline{\text { Second Location }}$}

Within the Geographic Area demographic, 7\% of respondents who listed a U.P. residence also listed an out of state residence in places like Arizona, Wisconsin, Nevada, Ohio, Indiana, Florida, and Pennsylvania (TABLE 4.5).

TABLE 4.5

FREQUENCY TABLE REPRESENTING RESPONSES FOR SECOND LOCATIONS

\begin{tabular}{|cl|r|r|}
\hline & Frequency & Percent \\
\hline \hline Valid & No Answer & 134 & 93 \\
& Arizona & 1 & 1 \\
Florida & 1 & 1 \\
Indiana & 1 & 1 \\
Nevada & 1 & 1 \\
Ohio & 1 & 1 \\
Pennsylvania & 1 & 1 \\
Wisconsin & 2 & 1 \\
Total & $\mathbf{1 4 2}$ & $\mathbf{1 0 0}$ \\
\hline
\end{tabular}


TABLE 4.6

FREQUENCY TABLE REPRESENTING RESPONSES FOR RESIDENCY

\begin{tabular}{|rl|r|r|}
\hline & Frequency & Percent \\
\hline \hline Valid & Year-Round & 87 & 62 \\
& No Answer & 29 & 20 \\
& Part-Time & 20 & 14 \\
Out of State & 3 & 2 \\
Student & 3 & 2 \\
& Total & $\mathbf{1 4 2}$ & $\mathbf{1 0 0}$ \\
\hline
\end{tabular}

\section{$\underline{\text { Residency }}$}

The majority response for the question regarding current residency status was Year-Round at $62 \%$, representing those who live in the Upper Peninsula (U.P.) all year (TABLE 4.6). Non-responses numbered 21\%. Part-Time residents represented 14\% of respondents. Two percent represented Students and another 2\% represented those who live Out of State.

\section{$\underline{\text { Past Visitation }}$}

When asked if they had attended the 2010 Cliff Mine tours, participants overwhelmingly responded No (76\%), with only 6 participants in total (4\%) who had attended the Cliff Mine tour the previous year and 20\% non-response (TABLE 4.7).

TABLE 4.7

FREQUENCY TABLE REPRESENTING RESPONSES FOR PARTICIPANTS WHO ALSO TOOK 2010 TOUR

\begin{tabular}{|cl|r|r|}
\hline & Frequency & Percent \\
\hline \hline Valid & No & 108 & 76 \\
& No Answer & 28 & 20 \\
& Yes & 6 & 4 \\
& Total & $\mathbf{1 4 2}$ & $\mathbf{1 0 0}$ \\
\hline
\end{tabular}


TABLE 4.8

FREQUENCY TABLE REPRESENTING RESPONSES FOR LOCALITY

\begin{tabular}{|rl|r|r|}
\hline & & Frequency & Percent \\
\hline \hline Valid & Local & 85 & 60 \\
& No Answer & 29 & 20 \\
& Non-Local & 28 & 20 \\
& Total & $\mathbf{1 4 2}$ & $\mathbf{1 0 0}$ \\
\hline
\end{tabular}

\section{$\underline{\text { Local or Non-Local }}$}

Respondents were asked to identify as "Local or Non-Local to the Upper Peninsula". The U.P. was chosen instead of the Keweenaw Peninsula to generalize local identity within a geographic boundary; ultimately, the distinction was left to the individual to make. Those who chose Local represented $60 \%$ of the respondents while $20 \%$ selected Non-Local. Non-answers comprised the last 20\% (TABLE 4.8).

\section{Activity Types}

Question one from the pre-tour survey asked respondents what activities they enjoy at the Cliff Mine site. Many people chose more than one activity (TABLE 4.9). Hiking (26\%) and Exploring (23\%) were the top two activities. The third most popular activity at the Cliff Mine site was Rock Collecting (15\%). The remaining seven activities ranked in order are Photography (13\%), Snowshoeing (6\%), Nothing (5\%), Other (including Hunting, 5\%), ATV (3\%), Other Collecting (2\%), and Snowmobiling (2\%). The selection of 'Nothing' likely indicates that the respondent has never been to the Cliff Mine. Many tour-goers were eager to divulge that since Cliff's deindustrialization in the 1930s, people have been exploring and enjoying the Cliff site for outdoor activities as well as for collecting iron (for scrap, resale, and collectibles) and minerals. 
TABLE 4.9

FREQUENCY TABLE REPRESENTING RESPONSES FOR ACTIVITY TYPES ENJOYED AT THE CLIFF SITE

\begin{tabular}{|l|r|r|}
\hline \multirow{2}{*}{} & \multicolumn{2}{|c|}{ Responses } \\
\cline { 2 - 3 } & Number & Percent \\
\hline \hline Hiking & 81 & 26 \\
Exploring & 76 & 23 \\
Rock-collecting & 47 & 15 \\
Photography & 44 & 13 \\
Snowshoeing & 18 & 6 \\
Nothing & 15 & 5 \\
Other & 12 & 4 \\
ATV & 10 & 3 \\
Snowmobiling & 6 & 2 \\
Other collecting & 6 & 2 \\
Hunting & 2 & 1 \\
Total & $\mathbf{3 1 7}$ & $\mathbf{1 0 0}$ \\
\hline
\end{tabular}

TABLE 4.10

\section{FREQUENCY TABLE REPRESENTING RESPONSES FOR MEDIA}

\begin{tabular}{|l|r|r|}
\hline \multirow{2}{*}{} & \multicolumn{2}{|c|}{ Responses } \\
\cline { 2 - 3 } & Number & Percent \\
\hline \hline Newspaper & 65 & 53 \\
Friends and Family & 25 & 20 \\
TV News & 8 & 6 \\
Radio & 7 & 5 \\
Internet Sites & 7 & 5 \\
Michigan Tech & 6 & 5 \\
Word of Mouth & 2 & 2 \\
An Organization & 2 & 2 \\
Drove By & 2 & 2 \\
Total & $\mathbf{1 2 4}$ & $\mathbf{1 0 0}$ \\
\hline
\end{tabular}

\section{$\underline{\text { Media Types }}$}

Participants were asked how they had heard about the Cliff Mine tours in an openended question. Generally, people identified nine sources of media which advertised the Tours. Many people listed more than one media source (TABLE 4.10). Fifty-three percent of respondents identified the two newspaper articles as sources with a distant second of 
$20 \%$ responses that indicated friends and family sharing the tour information with them. TV news (6\%), radio (5\%), internet sites (5\%), and MTU (5\%) were all very close for the third most cited sources for finding out about the tour. The remaining media types were local organizations $(2 \%)$, driving by $(2 \%)$, and through word of mouth $(2 \%)$.

\section{Qualitative Data: Pre-Tour Results}

The question of who attended the Cliff Mine field school tour was answered by the demographic data and supplemented by the following detailed qualitative questions. Approximately 116 respondents answered the qualitative section. Qualitative data collected from the Cliff Mine tour survey went through a coding process twice. First, specific categories were created for types of answers and then more general categories were written to understand ways the questions were answered in general. Some answers were more detailed than others, from one word answers to those that were a paragraph long. Data are organized in this section by ease of interpretation and simplicity of categorization. Coded categories are italicized. For the original survey, see Appendix A.

TABLE 4.11

HERITAGE SITE INTEREST: PRE-TOUR QUESTION 2 CODED RESPONSES

[QB2] What other archaeology and/or heritage sites do you have an interest in?

Specific Keweenaw/UP -- 51

General Keweenaw/UP -- 32

Specific hist. interests -- 12

Other countries/types of heritage -- 10

General historical interests -- 9

Parks -- 4

No interests -- 3

Total Responses: 121 


\section{$\underline{\text { Heritage Site Interest }}$}

The coding for this question generalized specific locations that respondents identified as having an interest in (TABLE 4.11). For example, if a respondent identified the Quincy Shaft Rock House, this would be coded into the Specific Keweenaw/UP category which was the largest response group. The results indicate that most respondents came to the Cliff Mine tour already having an interest in other historical sites, whether local or from around the country and world. Only three respondents said that they had No interests. Visitors were knowledgeable and exhibited self-selection bias.

\section{Memberships}

Fifty-four respondents had no memberships or experiences with archaeology. Less than half (44 local, 6 state and national) of the respondents were members of historical, heritage, or archaeological groups and organizations (TABLE 4.12). The most cited organization was the KCHS. Six participants expressed an interest in participating in an excavation and six others had related experiences or were members of related organizations. One respondent listed an organization that was unrelated to history or archaeology. This emphasizes the results from the previous question.

TABLE 4.12

MEMBERSHIPS: PRE-TOUR QUESTION 3 CODED RESPONSES

[QB3] Do you belong to any heritage, historical, or archaeological groups or clubs? Have you ever participated in an archaeological "dig"? Please explain.

No to both -- 54

Local organizations -- 44

No but interested -- 6

Related experiences/orgs -- 6

State/National organizations -- 6

Non-historical/archaeological orgs. -- 1

Total Responses: 117 
TABLE 4.13

MINING AND FAMILY: PRE-TOUR QUESTION 4 CODED RESPONSES

[QB4] Have you or a relative/ancestor worked in mining/mining-related industries? Does this relate to your interest in the Cliff Site?

No -- 47

Yes, relations -- 40

Somewhat related -- 8

No, but interested in history -- 3

Yes and No -- 3

Total Responses: 101

\section{Mining and Family}

Forty-seven responses said either no to both questions or simply No to both

(TABLE 4.13). About half of the respondents to this question expressed an interest in the Cliff Site because of their family's involvement in the mining industry. Yes, relations contained 40 responses which directly connected family history to involvement in heritage sites. Eight respondents said their family history was only Somewhat related to their interest and three respondents did indicate that while they have family members who were in the mining industry, it did not relate to their interests. Three responses said No, but interested in history. These results are valuable for understanding the audience for industrial history and archaeology in the Keweenaw Peninsula because they move beyond assumptions about visitors and prove that those who already have in interest in history are visiting historical sites. 
TABLE 4.14

IMPORTANCE OF TOUR: PRE-TOUR QUESTION 5 CODED RESPONSES

[QB5] Is it important to you to be able to tour or participate at archaeological sites? Why?

Importance of the past and history -40

Interests/emotional reasons -25

Yes -- 21

No -- 7

Miscellaneous reasons -- 6

Total Responses: 99

$\underline{\text { Importance of Tour }}$

Forty-four respondents found it important to have the opportunity to tour or participate at archaeological sites, primarily for the reason that history and the past are important to them (TABLE 4.14). Many of the responses from the Importance of the past and history category generally stated the importance of history to education and future generations or to know history so that past mistakes are not repeated. Responses like, "Yes, makes me feel more like a local, sense of place," and, "Yes, it's a good way to learn about your area," were quite common in the responses under the category of Interests and/or emotional reasons which had 25 responses. Twenty-one simply said Yes and seven said No without giving reasons why. Six responses gave Miscellaneous reasons for the importance of the tour, such as "Yes, it is fun."

\section{Prioritizing Sites}

Generally, respondents were very supportive of local preservation with 81 responses stating Yes when questioned (TABLE 4.15). Responses from the Yes, historical and/or educational category, 10 in total, commented that archaeological sites are "Irreplaceable," and that "Not much local history is taught post 3rd and 4th grades. None in high school." They also see a lot of value in archaeological sites, such as in this response: "Absolutely! Economically, socially, historically - there are so many benefits." The seven responses which included a caveat with their endorsement seemed concerned 
about the cost of preservation or the prioritization of preservation; these responses were included in the Yes, with a caveat category. Comments like, "Yes, but must be prioritized," and "Priority? We have many sites. I don't think we can save everything, especially in such an economically poor area," reflect practicality and show that some respondents are concerned about not only the cost of heritage preservation but also the number of heritage sites.

One respondent from the Yes, with a caveat category stated, "Yes, please don't close the rock piles to mineral collecting though!" A consistent concern was raised on-site about the availability of 'poor rock' (waste from hard rock mining) piles, which hobbyists and collectors search through by hand or shovel. Some visitors expressed concerns that the archaeology team would close off the mineral piles or had the perception that they could not search while the team was there. Some out of state visitors said that they were visiting the Upper Peninsula for the purpose of mineral collecting. A respondent who fits this profile was interviewed and is mentioned in Chapter Five. Only two respondents indicated Yes and no meaning they had some reservations about preservation but also supported it.

TABLE 4.15

\section{PRIORITIZING SITES: PRE-TOUR QUESTION 6 CODED RESPONSES}

[QB6] Should protecting or preserving archaeological sites be a priority in the Keweenaw?

Yes -- 81

Yes, historical/educational - 10

Yes, with caveat -- 7

Yes and No -- 2

Total Responses: 100 


\section{Expectations for Tour}

About $75 \%$ of total respondents indicated that they indeed had expectations of seeing or learning about specific aspects of Cliff Mine on the tour (TABLE 4.16). Less than $20 \%$ (17) of respondents identified that they had No/Vague expectations for the tour. There are four primary categories of expectations: History, Ruins, features, Excavation and/or archaeology, and Natural resources.

The History category comprises most of the responses relating to an expectation of learning. The responses in this category ranged from very specific ("How equipment and supplies got to location; how people lived in winter") to very unspecific ("Historical sites/use of the area"). Some had very specific places that they wished to learn about ("Foundation and layout of previous work sites", "Foundations of the stamps") which may indicate either very particular interests or previous knowledge of the Cliff Mine through reading about it or visiting. Ruins, features is somewhat related, but has more to do with responses that indicate an interest in examining the current and past landscape as well as curiosity about the remaining building foundations.

Only four respondents expected to see Excavation and/or archaeology. This category contains responses which clearly state the expectation that the visitor will see an excavation, something that was stated in several news articles and on the television news segment about the Cliff. Natural resources refers to the desire of the participant to know what resources were available or used by the miners at the Cliff, such as forest products; only two responses fell into this category.

TABLE 4.16

\section{EXPECTATIONS FOR TOUR: PRE-TOUR QUESTION 7 CODED RESPONSES}

\begin{tabular}{|l|}
\hline [QB7] What do you expect to see or to learn about on your tour today? \\
\hline \hline History -- 55 \\
\hline No/vague expectations -- 17 \\
\hline Ruins, features -- 14 \\
\hline Excavation/archaeology -- 4 \\
\hline Natural resources -- 2 \\
\hline
\end{tabular}




\section{TABLE 4.17 \\ PARTICIPATION OPPORTUNITIES: PRE-TOUR QUESTION 9 CODED RESPONSES}

\begin{tabular}{|l|}
\hline $\begin{array}{l}\text { [QB9] Should there be more opportunities for participating in archaeology and } \\
\text { heritage events in the Keweenaw? }\end{array}$ \\
\hline \hline Yes -- 84 \\
\hline Yes, value statement -- 13 \\
\hline Unsure/already opportunities -- 2 \\
\hline \hline
\end{tabular}

\section{$\underline{\text { Participation Opportunities }}$}

Responses fell into three categories for this question: Yes, Yes, value statement, or Unsure/Already opportunities (TABLE 4.17). The general Yes category had 84 responses and Yes, value statement had 13. Yes, value statement indicates that the response had a value statement attached to their answer of Yes such as, "Yes, I think people would be interested," and, "Yes, educate the public which will help preserve history." Respondents generally valued archaeology and heritage through the sharing of history, education, being involved in events, or, in one response, indicating that "available programs exist." Two responses indicated that there were already opportunities for participation or were unsure. Overall, the responses to this question indicate a strong support of archaeology and heritage among visitors to the Cliff Mine tour.

\section{$\underline{\text { Further Opportunities }}$}

Twenty-five responses identified specific Keweenaw or Upper Peninsula locations indicating, as in the first qualitative survey question, that visitors were familiar with local historical sites (TABLE 4.18). Of these, 11 referenced Central Mine (a site owned by the KCHS and very close to the Cliff Mine) or another Keweenaw County historical site and 10 responses referenced a Quincy Mining Company, Calumet \& Hecla Mining Company, or other Houghton County mining site. Only one respondent identified an Ontonagon County historical site and two referenced Cliff or Clifton. In this instance, such specific responses may represent a desire to experience something new at these sites 
or further exploration of what is already known there.

Eighteen respondents indicated a Specific activity they would like to do at unspecified sites. Most respondents indicated that they would like to tour or visit other sites or to learn and volunteer. Twelve respondents were Unsure. The nine General place and/or activity responses were very unspecific but positive with answers such as Yes, Anywhere, or Any activity. Five respondents wanted to participate in activities or go to places that were General[ly] mining related while two respondents indicated they would like to visit Prehistoric sites.

\section{Qualitative Data: Post-Tour Results}

Goals for the Post-Tour survey were to measure similarities and differences between the Pre- and Post-Tour answers as well as to query visitors on the quality of their experiences. Another goal was to identify changes to visitor values on the subjects of archaeology and heritage preservation.

TABLE 4.18

\section{FURTHER OPPORTUNITIES: PRE-TOUR QUESTION 10 CODED RESPONSES}

\begin{tabular}{|l|}
\hline $\begin{array}{l}\text { [QB10] If so, where would you like to see further public archaeology } \\
\text { opportunities and what would you like to do there? }\end{array}$ \\
\hline \hline Specific Keweenaw/UP -- 25 \\
\hline Specific activity -- 18 \\
\hline Unsure -- 12 \\
\hline General place/activity -- 9 \\
\hline General mining related -- 5 \\
\hline Prehistoric -2 \\
\hline
\end{tabular}


FUTURE PARTICIPATION: POST-TOUR QUESTION 1 CODED RESPONSES

[QP1] Would you participate in a tour of an archaeological site again? Why or why not?

Yes because of history -- 47

Yes -29

Yes, enjoyable, good tour -- 22

Yes, concern for site/desire for more -2

No/felt left out -- 2

Total Responses: 102

\section{Future Participation}

Forty-seven respondents claimed history as the main factor in their future visitation to archaeological sites (TABLE 4.19). The 29 responses in the category Yes seem to have felt that no improvement was necessary because the tour was already satisfactory and had no further statement to make. In responses from the category Yes, enjoyable, good tour, comments went beyond yes, such as, "Yes, terrific job done by the students, really opens up my mind and curiosity to the lifestyle back then and today," and, "Yes, very enjoyable. Great to see people excited about history."

Two respondents had concern for the site and its future as well as a desire to see more of the site excavated. The No/felt left out responses included one response about insect pests on-site and the second response in this category indicates that the respondent did not have their questions answered. They said that the crew was selective about whose questions they answered.

\section{Tour Improvements}

Responses in the category No improvement had generally positive things to say or were satisfied with the tour (TABLE 4.20). The two main categories of improvements to the tour were Tour guide and/or group improvement and Include aids. The Include aids category (27 responses) included responses that suggested improvement in the area of 
physical and visual aids, such as signs and maps. Several respondents suggested bug spray as an improvement and one respondent indicated a desire to see "Indian artifacts." The aids mentioned most often were map handouts (or brochures) and signs to help people interpret the site when hiking without tour guides. It was difficult for some visitors to envision the Cliff Mine site without knowing which building foundations had what function or purpose when the mine was in use. This seems to be at least related to the comments from some respondents about needing to "read up" on the area before attending.

The 23 responses in the Tour guide and/or group improvement category offered advice for improving the tour by having the tour guide either use an aid to help them speak louder or for them to speak louder, shortening the tour, taking smaller groups of participants, getting more information from the students, and having more interpreters on-site. Several respondents also indicated that they felt they should have researched the site more before attending. Some responses indicated there should be no improvement (16) and seven respondents were unsure.

TABLE 4.20

TOUR IMPROVEMENTS: POST-TOUR QUESTION 2 CODED RESPONSES

\begin{tabular}{|l|}
\hline [QP2] How could your tour experience have been improved? \\
\hline \hline Include aids -- 27 \\
\hline Tour guide/group improvement -- 23 \\
\hline No improvement -- 16 \\
\hline Unsure -- 7 \\
\hline \hline
\end{tabular}




\section{$\underline{\text { On-Site Questions }}$}

Overall, participants had their questions answered by the field school team, as shown in the Yes and Positive comment categories (TABLE 4.21). Yes included 46 responses. Fourteen of the 34 Positive comments indicated that the participant learned a lot and the guides took the time to help them learn about aspects of the site they were interested in. There were four responses in this category indicating that the respondent wanted to learn about what the tour guides and students did not know, such as this respondent who said, "Yes, but need more [information] about poor rock and stamp sands," illustrating how some participants are thinking about more than what was presented to them.

Two respondents, whose comments are included in the Maybe and Positive comment category, indicated that the questions that they asked during the tour were not able to be answered by the tour guide. The research may have not been clear or complete enough to supply this respondent with a clear answer. The miscellaneous comments in the No questions or miscellaneous comments category were mostly about the participant's questions being asked by others in their tour group or that some questions are unanswerable. Maybe consisted of only three responses.

TABLE 4.21

ON-SITE QUESTIONS: POST-TOUR QUESTION 3 CODED RESPONSES

\begin{tabular}{|l|}
\hline [QP3] Were the questions you had about Cliff Mine answered? Please explain. \\
\hline \hline Yes -- 46 \\
\hline Positive comments -- 34 \\
\hline No questions/miscellaneous comments - 10 \\
\hline Maybe - 3 \\
\hline \hline
\end{tabular}




\section{Expectations for Tour Post-Tour}

Only $6 \%$ of the responses to this question fall outside of the Yes or Yes, positive comment groups (TABLE 4.22). Yes contained 71 comments and in the Yes, positive comment category, there were 23 responses. Seven responses in this category indicated that the respondents "Could have learned more" about the site or would like to know the outcomes at the site. Five respondents indicated that they had their expectations exceeded and two wanted information on how to volunteer on-site. Because most respondents had expectations pertaining to history, it was unsurprising that most respondents indicated that these expectations had been met and made no mention of a lack of archaeological information.

Most of the respondents reiterated an Improvement (5 responses) to the site. One improvement was really a complaint which stated that there was, "... No information about archaeology," on the tour but the respondent had given no response for the PreTour question (TABLE 4.16) about their expectations, so it was difficult to know what they had expected to learn about archaeology. One response plainly stated, "No," without explanation.

TABLE 4.22

EXPECTATIONS FOR TOUR POST-TOUR: POST-TOUR QUESTION 4 CODED RESPONSES

\begin{tabular}{|l|}
\hline [QP4] Were the questions you had about Cliff Mine answered? Please explain. \\
\hline \hline Yes -- 71 \\
\hline Yes, positive comments -- 23 \\
\hline Improvement -- 5 \\
\hline No -- 1 \\
\hline \hline \\
\hline
\end{tabular}




\section{$\underline{\text { Importance of Tour Post-Tour }}$}

Respondents had many positive responses to this question despite there being fewer responses than in the Pre-Tour survey (TABLE 4.23). However, five No responses from the similar Pre-Tour survey question (TABLE 4.14) changed to positive responses (in the Yes and Yes, positive comment categories) at this point in the survey. Some of the respondents whose opinions changed made comments such as, "Yes, connects us to the history of the place," "Yes, but still not a high priority," and, "Yes, the history of how the archaeology of the area influenced and caused the movement of people from all over the world to this region." So at least two participants had a transformative experience that changed how they valued their involvement in touring archaeological sites and their ability to do so.

In the Yes, positive comment category, some respondents also identified history as an important facet of life and that, "historical information is being lost." This urgency to teach others about history was, to one respondent, a moral issue: "Yes, it's wrong to not learn about the past." Comments were generally about the importance of learning history and the lives of ancestors, connecting to the past and to the local area, and the enjoyment of archaeology and tours in general. Yes category responses followed, with a total of 26.

\section{TABLE 4.23}

IMPORTANCE OF TOUR POST-TOUR: POST-TOUR QUESTION 5 CODED RESPONSES

\begin{tabular}{|l|}
\hline $\begin{array}{l}\text { [QP5] Now that you have completed the tour, is it important to you to be able } \\
\text { to tour archaeological sites? Why? }\end{array}$ \\
\hline \hline Yes, positive comment -- 50 \\
\hline Yes -- 26 \\
\hline Yes, support heritage -- 14 \\
\hline No or miscellaneous comment -- 2 \\
\hline \hline
\end{tabular}


TABLE 4.24

PRIORITIZING SITES POST-TOUR: POST-TOUR QUESTION 6 CODED RESPONSES

\begin{tabular}{|l|}
\hline $\begin{array}{l}\text { [QP6] After viewing the Cliff site, should protecting or preserving } \\
\text { archaeological sites be a priority in the Keweenaw? Please explain. }\end{array}$ \\
\hline \hline Yes -- 33 \\
\hline Yes, historical/educational reason -- 24 \\
\hline Yes, concerns/site threatened -- 21 \\
\hline With a caveat -- 11 \\
\hline Yes, helpful/suggestion -- 5 \\
\hline
\end{tabular}

\section{Prioritizing Sites Post-Visit}

Responses to this question were unanimously Yes, as 33 responses simply said Yes (TABLE 4.24). Responses in the Yes, historical or educational reason category, numbering 24, found the historical and educational reasons for preservation compelling. Thirteen of these respondents specifically cited the safeguarding of history for future generations as a primary reason for supporting preservation. Keeping with this theme, the remaining 11 respondents indicated that history was important educationally and to the heritage of the area. One respondent in particular stated, "Yes, [for] one reason, simply to preserve our history."

Twenty-one respondents had concerns about the Cliff itself or other sites being threatened. Some indicated that, "Yes, we've already lost a lot," and, "Absolutely! I'm disappointed in seeing many poor rock piles and stamp sand beaches disappear," which shows not only familiarity with local history but also a perception that those historical sites and features are vanishing. Some respondents also voiced concern about the collection of artifacts, saying, "Too much of the valuable and historic items have been taken away by unknowns through the years," and, "Yes, how [would it] protect [the sites] from nighttime vandals?" Respondents in this category are clearly concerned with the future of heritage sites in the Keweenaw.

Eleven responses included a caveat with their Yes statements. Some said that 
preservation was still not, "a high priority," asked that we, "allow rock hounding in dumps," and some preferred to preserve a, "representative sample," "depending on the site," because, "this area does not have the money to preserve everything." Funding preservation projects and selecting appropriate sites for preservation were the main concerns of those with a caveat.

In the category, 'Yes, helpful or had suggestions for tour,' four respondents indicated that preservation led to tourism, which was good for the area. "Yes, selfishly it enhances tourism," said one respondent and another stated, "Yes, more people should have the opportunity to see the historical sites, [they are] great tourist attractions." The one other respondent in this category reiterated their desire to see signage at the Cliff Mine site.

\section{Participation Opportunities Post-Tour}

Responses to this question were mostly straightforward Yes responses, numbering 69 in total (TABLE 4.25). About one fourth of responses fell into either the Yes, other comments or No/Unsure categories; the 17 responses in the former category were incredibly varied. Three comments indicated that there should be "as many [tours] as practically possible," and, "as many [tours] as possible." Two comments mentioned that there should be more opportunities because, as one respondent said, "Just look at the turnout and interest" and other respondents pointed out that there was public interest and an interest in volunteering at sites, or as one put it, a "tourism bonanza!" Another respondent encouraged us to "Keep it up!" and another indicated that it would, "help preserve" sites. The remaining comments addressed the educational benefits, need for further research, and indicated that other organizations and sites were working on offering more events.

In the $N o$ /Unsure category, there was little explanation for the position of the respondent on this question. "No, not necessarily," and "Perhaps," are examples of how vague the responses were, however one response in this category does explain further by saying, "Many people don't use what is here now." This response seems to imply that heritage events and resources in the Keweenaw are poorly attended or underutilized. 


\section{Further Opportunities Post-Tour}

There were 13 more answers to this question in the Post-Tour survey (TABLE 4.18) than the Pre-Tour survey where the same question was asked (TABLE 4.26). Just about the same amount of responses fell into the Specific place in Keweenaw/UP category (26) as in the Pre-Tour survey question but respondents branched out and referenced different heritage sites than they did before. The General positive response category had 23 responses. Some of the other responses in this category included additional recommendations and expressed general interest in all mining-related heritages.

TABLE 4.25

PARTICIPATION OPPORTUNITIES POST-TOUR: POST-TOUR QUESTION 7 CODED RESPONSES

\begin{tabular}{|l|}
\hline $\begin{array}{l}\text { [QP7] Should there be more opportunities for participating in archaeology and } \\
\text { heritage events in the Keweenaw? }\end{array}$ \\
\hline \hline Yes -- 69 \\
\hline Yes, other comments -- 17 \\
\hline No/Unsure -- 5 \\
\hline \hline
\end{tabular}

TABLE 4.26

FURTHER OPPORTUNITIES POST-TOUR: POST-TOUR QUESTION 8 CODED RESPONSES

\begin{tabular}{|l|}
\hline $\begin{array}{l}\text { [QP8] If yes to question 7, where would you like to experience public archaeology } \\
\text { opportunities in the Keweenaw and what would you like to be able to do there? }\end{array}$ \\
\hline Specific place in Keweenaw/UP -- 26 \\
\hline General positive response -- 23 \\
\hline Specific activity -- 17 \\
\hline Unsure/unknown - 12 \\
\hline Specific interest -- 6 \\
\hline
\end{tabular}


Seven respondents in the Specific activity category referenced education and teaching children as activities they would enjoy. Seven other respondents identified volunteering and assisting in the excavations as something they would like to do and the remaining responses in this category were interested in site reuse and touring, exploring, and visiting other sites. There were about the same number of Unsure/Unknown category responses to this question in the Pre- and Post-Tour (around 12). Specific interest, which includes six responses, tended to reference interests such as Native American or prehistoric heritage, logging, mining and industrial technologies, and social history.

\section{Future Research}

Many respondents identified areas or themes at the Cliff Mine site about which they would like to see further research (TABLE 4.27). Twenty-six of the responses in the category Specific place and/or theme at Cliff were split; 13 had a desire to see more research conducted at Clifton, the town site associated with the Cliff Mine, and the remaining 13 were interested in the lives of miners and their families. Work done on-site in 2011 primarily concerned the the second stamp mill and the Cliff Mine tour did not cover social aspects of the site. Five respondents identified specific buildings and areas and another respondent wanted to know how the Cliff Mine operated. Other responses in this category called for a detailed history of the Cliff, an understanding of the evolution of the site, how the landscape changed over time, and to excavate other mine sites.

TABLE 4.27

FUTURE RESEARCH: POST-TOUR QUESTION 9 CODED RESPONSES

\begin{tabular}{|l|}
\hline [QP9] In the future, where would you like to see more archaeology done at the \\
Cliff Site? What research questions about the site would you like to see \\
answered (ex: how long did workers stay at Cliff, etc.)?
\end{tabular}


The 19 comments from the Yes/Unsure category are self-explanatory. The Suggestions category had a total of nine comments. Seven of those comments repeated earlier recommendations for maps and signs at the site. This category also included the comment, "Yes, but keeping the remoteness/quaintness of the site is important [because] it's part of the beauty of the site," with the remaining comment suggesting that the tour guides present, "A typical week at the Cliff." Other comments contained four responses of "anywhere" and essentially, everywhere. Another four responses in this category essentially said, "Let the experts determine," and, "Depends on experts." The remaining comment wanted to see "All of it and preserved!" Considering 14 of the 19 responses in the Yes/Unsure category are "Yes," leaving 5 "Unsure" responses, the vast majority of respondents support archaeological activity in the Keweenaw, even if they do not know where they would like it to be done.

\section{$\underline{\text { Public Involvement }}$}

Overall, responses to this question were generally positive and were split into three categories: Yes, Yes, great tour, and Yes, improvements (TABLE 4.28). The general Yes category contained 44 responses and Yes, great tour included 31. Yes, great tour was a category created for comments that praised the tour guides and students at the site. Some of the representative comments include, "Yes, friendly, patient and enthusiastic," "Yes, patience in questions, knowledgeable and able to communicate," and, "Yes, very open and Keweenaw friendly." There were also responses to this question which were positive but vaguely recommended 'improvements,' leading to the next response category.

The category Unsure/Vague answer had responses like, "No, this is the first I have seen." The respondent had otherwise positive responses to the other survey questions, so the response was categorized as Unsure/Vague answer. Other responses in this category were, "Which people?" "Not sure, I've never seen a call for volunteers," "Not sure what you mean by 'people,," and, "No, seems to be too few."

Three of the responses in the Yes, improvements category indicated that there needed to be more inclusion, such as in this response: "We have some people in their 90s who are excellent historians that may be incorporated into the project rather than just 
getting information from some of the local authors who are younger." Other responses in this category noticed the good and the bad points related to having large groups near an archaeological site, suggested a way to donate on-site, and the rest suggested improvements in the tour, such as, "Need of a few good interpreters at the site; give us a good Cousin Jack in period garb to describe/entertain.” By 'Cousin Jack' the respondent is referring to a colloquial term for a Cornish miner.

TABLE 4.28

PUBLIC INVOLVEMENT: POST-TOUR QUESTION 10 CODED RESPONSES

\begin{tabular}{|l|}
\hline $\begin{array}{l}\text { [QP10] From your experiences on the tour, do you think the archaeologists do } \\
\text { a good job of incorporating people into projects like the Cliff? Why? }\end{array}$ \\
\hline \hline Yes -- 44 \\
\hline Yes, great tour -- 31 \\
\hline Unsure/vague answer -- 9 \\
\hline Yes, improvements -8 \\
\hline
\end{tabular}

TABLE 4.29

FUTURE HERITAGE VISITATION: POST-TOUR QUESTION 11 CODED RESPONSES

\begin{tabular}{|l|}
\hline $\begin{array}{l}\text { [QP11] From your experiences on the tour, do you think the archaeologists do } \\
\text { a good job of incorporating people into projects like the Cliff? Why? }\end{array}$ \\
\hline \hline Specific activities/programs -- 26 \\
\hline Unsure -14 \\
\hline Specific interest -- 7 \\
\hline General interest -- 6 \\
\hline
\end{tabular}




\section{$\underline{\text { Future Heritage Visitation }}$}

The responses to Post-Tour Question 11 amount to about half of the typical number of responses to any other question in the survey; understandably, respondents may have been in a hurry to finish and neglected the final question (TABLE 4.29). About $75 \%$ of the collected responses to this question identified a General interest, Specific interest, or Specific activities and/or programs.

Specific activities and/or programs was the largest coding category with 26 responses. Six of those respondents indicated that they would be more apt to attend lectures or presentations on heritage in the future, such as one respondent who would like to see, "Public speakers and tours of archaeological sites." Several respondents wanted to tour, visit, and explore other archaeological and historical sites (one said, "these field trips are the best way to share information rather than talks in town"), join history or heritage groups, take courses at MTU, and attend future Cliff Mine tours. Two respondents indicated that they would (or that the team at Cliff should), "Show the community." Fourteen responses fell into the 'Unsure' category.

Those with a Specific interest identified particular aspects of heritage that they would pursue further. One respondent indicated interest in Native American mining, two others wanted to pursue social history, and three respondents indicated that they would like to do more research on the Cliff Mine. One troubling response was, "Looking for historical artifacts!" It was unclear what this participant meant by this comment as they could not be reached for an interview, but this response was certainly interesting and the most ethically challenging of any other response in the survey. The General interest category included six responses stating that the participant would like to do anything, anywhere or that they were going to, “...keep my eye out for other opportunities," in the words of one respondent.

\section{Questions and Comments}

Respondents had two opportunities to add additional questions and comments: one open comments question at the end of the Pre-Tour survey and one at the end of the Post-Tour survey. Eleven respondents on the Pre-Tour survey either thanked the crew for 
the opportunity ("Thanks so much for interrupting your work to explain what we are looking at.") or had a positive comment such as, "Good luck. Preserve as much as you can!" Two additional comments addressed preservation specifically, one ending their response with a concern: "I understand reburying [the] site but how can revisiting be accomplished?" It was clear on-site that there were visitors who wanted to bring people back or return at a later time to see the excavated section of the mill and were upset when we informed them that we would be reburying the site.

The last response on the Pre-Tour survey comment section concerned providing information to the public. The comment read, "Very interesting. Wonder about the level of documentation and what will be made available to the public. Probably would be better with signage developed from blog or other sources and to have an interpreter there to allow for the students to work." This comment is both a question inquiring about the availability of the research conducted at the Cliff Mine to the public and a suggestion for improvements to the tour. The comment also expresses an indirect criticism of the students' abilities or motivations to interpret for visitors.

At the end of the Post-Tour survey, respondents were again asked to provide additional questions and comments they may have had. Again, 11 respondents had generally positive things to say such as, "Great job! Thank you," and, "No, well done, I am [a] first time visitor." One respondent began following the blog, one felt that Clifton needed to be researched to hear, “...more about the miner's town - dwellings - lives of folks other than daily mining, too," and two others stated that the Cliff Mine is, "an important site that needs more attention." There were two suggestions, one recommending interpretive signs and another stating, "Make sure the tour guides take time to explain things," possibly indicating how rushed the tour was. One last helpful commenter thought that, "some of the [survey] questions were too repetitive."

\section{Discussion: Demographics}

Within the age demographic results, a few age groups were underrepresented, particularly the ages $26-45$. When the age demographic data were compared to other industrial heritage site visitor surveys, this was a common gap in attendant age groups 
across all industrial heritage sites (Cameron and Gatewood 2000; Ramos and Duganne 2000:21; Stynes and Sun 2004a, 2004b, 2005; Stanton 2006:239).

Another type of demographic data which were similar to those of the cited surveys were those of occupation, particularly the amount of white-collar participants. However, most of these surveys requested additional demographics such as Yearly Income and Education Level to create a stronger profile of their visitors and the Cliff Mine tour survey data did not. It is unsurprising for there to be so many retired visitors because $24 \%$ of the residents of Keweenaw County are aged 65 and over, $10 \%$ more than the rest of Michigan at $14 \%{ }^{7}$.

A surprisingly uneven distribution of gender came from the gender demographic data when compared to a national trend in the visitation of heritage and archaeological sites (Cameron and Gatewood, 2000; Ramos and Duganne 2000:21; Stynes and Sun 2004; Stynes and Sun 2005; Stanton 2006:239). For example, when compared to those surveyed at an industrial heritage site such as Lowell National Historical Park, this was a low number of female participants (Stanton 2006:239). Females typically outnumbered males in surveys taken at heritage sites males outnumbered females at the Cliff Mine.

The results for geographic area were expected to include a higher percentage of non-local respondents because the tour happened during the summer tourism season. The 2004 Keweenaw National Historical Park Visitor Study found similar percentages of visitors from other states as in the Cliff Mine survey (KNHP 2004:12). The Cliff Mine survey respondents listed their Upper Peninsula residency as Part Time or Out of State. Some Part-Time respondents mentioned on-site that because of their advanced age, it was easier to live in an urban or suburban environment during the winter. Some respondents on-site indicated that they had professional ties to other areas in the United States because, while they were local, they had careers elsewhere that they could not have in the Keweenaw. However, in FIGURE 4.12 it is shown that a great majority of respondents were locals who lived in the Keweenaw Peninsula (either Houghton or Keweenaw Counties) year-round.

Only six respondents indicated that they had attended the 2010 Cliff Mine tour the

\footnotetext{
${ }^{7}$ http://quickfacts.census.gov/qfd/states/26/26083.html
} 


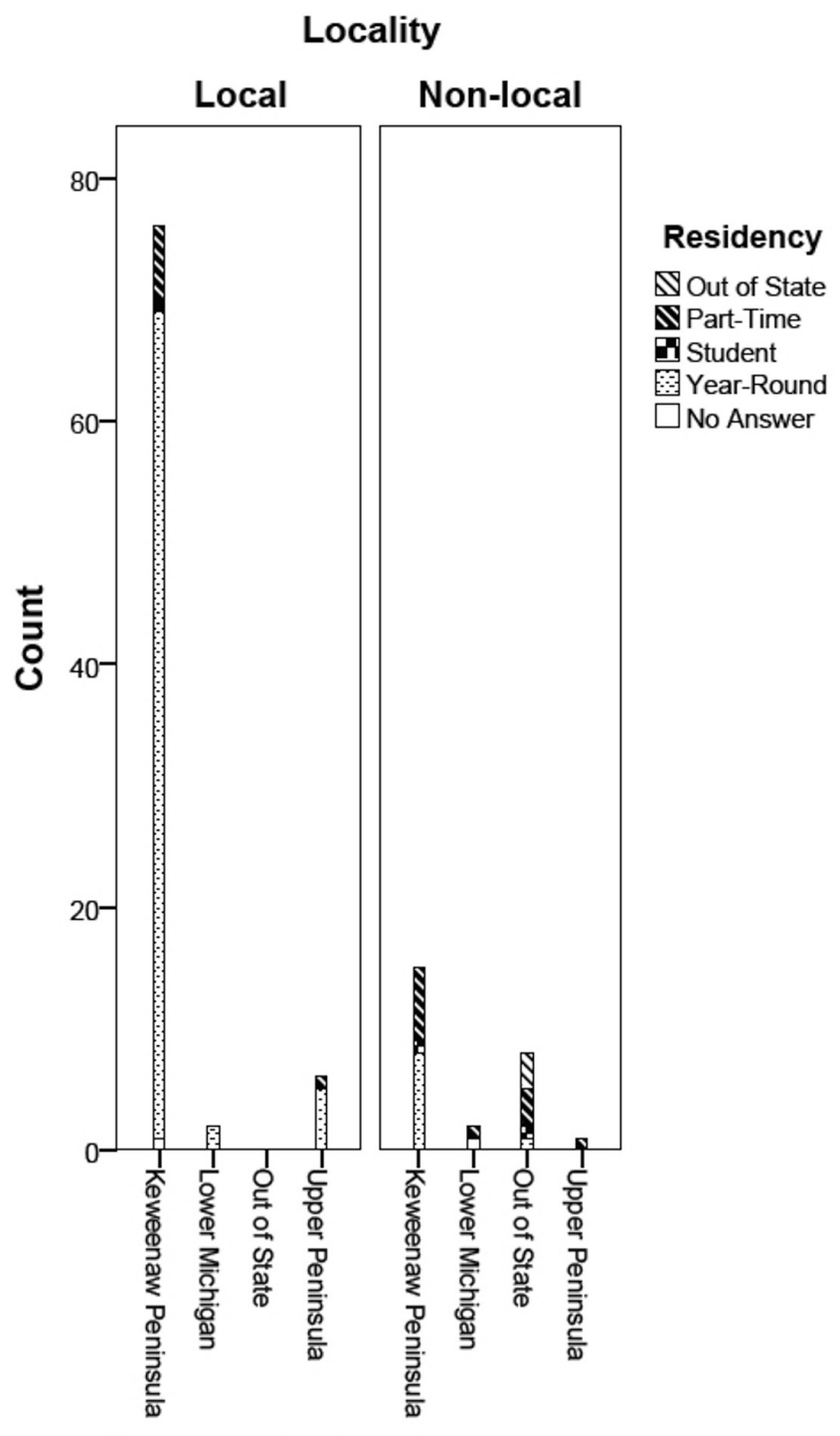

Geographic Area (generalized)

FIGURE 4.2: Geographic Area Categorized by Residency and Separated by Locality (Created by the author with SPSS).

previous year. More visitors did attend in 2011 than in 2010 but it was curious as to why there were few repeat visitors in 2011. The most significant aspect of the media types demographic was that the newspaper (regardless of if it was accessed online or not) was the most influential media for advertising tour events. This was not surprising considering the age groups who referenced the newspaper.

In the Keweenaw National Historical Park Visitor Study, respondents were asked 
if they were residents of the Keweenaw Peninsula, to which only $13 \%$ of about 350 respondents answered 'Yes' (2004: 19). Within the Cliff Mine survey's data set, if the question of locality and residency are compared with current geographic residence (FIGURE 4.2), a higher number of local, year-round residents of the Keweenaw attended the Cliff Mine tours than went to the KNHP in 2004. The reason for this disparity could be as simple as the novelty of an archaeological site in the Keweenaw.

Some of the notes written next to the demographic question requesting locality were interesting, as were the questions visitors asked on-site about locality. Respondents were sometimes wary of labeling themselves as local when they had not lived here, as they put it, "long enough." Some asked on-site, "How long does it take to be a local?" which was something that the respondents were encouraged to answer based on their own perceptions of locality. The ideas respondents had about what makes a person 'local' or not were developed into interview questions to collect further data.

The residents of the Keweenaw Peninsula have a hierarchical view of "localness", perhaps out of a sense of self-preservation. In once-industrial areas in the United States, the sense of loss can cut across years, in this case almost 100, to create a strong sense of place and identity centered on what the once-successful industry brought to the area (High and Lewis 2007). Romanelli and Khessina (2005:345) identify this as a Regional Industrial Identity, but in this case it was the identity of a rural and deindustrialized community with very little contemporary industrial influence, not that of an urban community. The differences in identities of "non-/local-ness" can cause rifts outside of the unifying 'constitutive narrative' congruent to the Youngstown of High and Lewis' Corporate Wasteland (2007:83). In Chapter Five, interviews were conducted that explored local and non-local identity in-depth.

Analysis of the activity types demographic leads to an understanding of what people do at Cliff outside of a heritage-based interest and how those activities may influence preservation at the site. Mineral collecting was the most important activity listed under this demographic for many reasons. It is an activity that, when involving metal detectors, causes visitors who are enjoying natural aspects of the site some disturbance. Regardless, it was an important activity for visitors. 
One respondent in the qualitative section mentioned that it was important to keep the site available for mineral collecting. Preserving the availability of the mineral piles to the public was definitely a concern voiced by many people who stopped by the site while the field school was underway. Some were only at the site to collect minerals while others wanted to see the excavation and hear history about the Cliff in addition to collecting minerals. While some other activities, such as ATV-riding and snowmobiling, could be considered just as contentious as mineral collecting, their numbers were fewer compared to collectors.

\section{Discussion: Qualitative Data}

Through all of the demographic information, there were a few characteristics of the participants that predicted their interest in local heritage. Male and female participants were just as likely to be interested in social history; however males were more likely than females to have an interest in the technical processes of mining. Participants with ancestors in the mining industry answered questions without distinction from visitors who claimed no mining-related heritage. Respondents focused on the historical aspects of the site rather than the physical process of archaeology but the experience of seeing an archaeological site was important to their visit. Visitors tended to be self-selected and predisposed to an interest in history. Overall, the participants at the Cliff Mine field school tours were very supportive of the preservation of history and archaeological sites.

Those who felt differently than the majority had many valuable responses. A few advocated keeping the site open to mineral collectors or to keeping the site intact the way it is. There were those who expressed concern over the disappearance of other historical sites and those who felt that there were already enough historical sites preserved. A few indicated that funding preservation projects could be difficult in an economically depressed area, or they wondered where the money would come from.

Visitors overwhelmingly enjoyed themselves on the Cliff Mine tour according to survey data. However, there were also quite a few helpful suggestions made about improving the tour for visitors. One of the most frequent suggestions was to place interpretive signage near the building foundations so that participants knew what the 
buildings were or were used for. Another respondent suggested creating maps or brochures for visitors and labeling building foundations and the locations of buildings through time within this map or brochure. This would also require research and design time as well as funding but could be a useful outreach tool and a reference for the field school students on-site.

A couple of participants indicated an interest in Native American/prehistoric archaeology in the Keweenaw. When tour participants on-site asked about Native American artifacts or about finding artifacts, it was always suggested to the visitor by the author that anything of archaeological value remain "in context." The concept of context was explained to visitors by the author as 'the information surrounding the object in the ground,' information that is needed to understand as much as possible about the artifact.

One shortcoming of the on-site survey collection method was that more oral commentary was not recorded. Many visitors wanted to talk about their experiences exploring the Cliff Mine site, particularly about the state of decay in the Protestant cemetery nearby. Several people expressed horror and sadness concerning holes that had been dug near the graves or that headstones were displaced. Only one respondent mentioned the cemetery in the survey, in response to "where they would like to see future archaeology conducted."

Other interesting verbal comments noted on-site were from three males who worked as miners in the past. None of these men completed a survey but they did elaborate that they either worked in the iron mines of Minnesota or Marquette or worked at White Pine Mine (Michigan) before it closed in 1994. One man was very gracious and kept repeating how much he appreciated that the archaeology team was working on a mining site. He felt that the story of miners was one that needed to stay in the public consciousness and told me that he had worked in the Minnesota iron mines driving a truck after spending a year or so underground in the Copper Country. Each of these men was told how valued their contributions to the project would be but each one said that no one would want to hear what he had to say or that the "ramblings" of an "old man" were not important. Only one survey respondent specified that he worked in the mining industry but did not indicate in what capacity. 
Finally, one of the last great concerns voiced at the site was that of mineral collectors and metal detectors. A number of people showed up at the Cliff site during the extent of the field school to pick through the poor rock piles looking for copper and other minerals, as well as people with metal detectors who were looking for metal or metal objects. Some approached the field school to see what was going on and asked if their activities were okay, and others went about their business without approaching us. During tour days, many of them asked if they were still allowed to metal detect, or to collect. A few respondents in the survey addressed keeping rock collecting (or "hounding") open to visitors as a concern for the Cliff site.

\section{Conclusions on Survey Results}

Overall, the survey was successful in gathering important information about the values and attitudes that visitors to the Cliff Mine site had about the site itself, preservation, and heritage site visitation. The survey also provided important visitor profiles that can be expanded upon and used in the future. The survey design, however, had some more successful elements than others.

The Pre-Tour and Post-Tour design did provide unique data but may have worked better as a shorter survey due to the absence of tables and chairs and the summer outdoor setting. The primary issue was that many respondents answered very tersely and without explanation. The longer answers and interviews had to be relied on for deeper response analysis. The weather and insects out on the tour days could have affected results due to the discomfort of standing still outside to complete a long survey.

The Post-Tour survey appeared unnecessarily redundant to many participants onsite despite best intentions. The original plan for the Post-Tour survey was to have participants return the survey by mail, including pre-paid postage on the survey with instructions on sending it in. While this may have increased the detail with which participants filled out the survey, it was unfeasible. An on-site methodology aided the collection of contact information necessary for interviewing participants. 


\section{Conclusion}

The visitors and survey participants at the Cliff Mine field school tours in 2011 were very similar in profile to visitors at industrial heritage sites from other regions in the United States. The demographics showed that a majority of participants were of either gender and over 46, were retirees or in the education industry, who found out about the tours through newspaper articles; they were also local, year-round residents of the Keweenaw Peninsula who enjoyed hiking, exploring, and mineral collecting at the Cliff Mine. This profile certainly fits patterns of heritage site visitation found in analyzing prior surveys from the literature review (Gatewood and Campbell 2000; Le et al. 2005; Stanton 2006; Stynes and Sun 2004a, 2004b, 2005).

From analyzing the qualitative data, the visitor profile formed from demographic data was reinforced. Participants arrived at the site with an interest in history and local heritage and could readily identify other local industrial heritage sites. Generally, participants had ancestors or relatives (including themselves) who worked in the mining industry and this ancestry influenced their interest in industrial heritage. Most participants were not members of history, heritage, or archaeological groups and organizations, but when they were, it was typically a membership in the local KCHS. Participants were positive and pro-preservation with very few negative or critical responses. They were concerned with the disappearance of history, felt that historical sites offered educational opportunities, and wanted to know more about the social lives of the people who once populated such sites.

Non-answers or simple 'Yes' and 'No' answers were not particularly helpful to the survey overall. In hindsight, some of the qualitative questions could have been changed into quantitative questions and generally, the survey could have been much shorter. A more focused set of questions could have yielded a stronger data set for the survey. A shorter survey could also improve the pre- and post-tour survey format, allowing for more detail on fewer subjects.

Gaps in the survey data were expanded upon in interviews after analyzing the survey data. Many questions remained unasked, such as, "What makes people local to the Keweenaw?" A deeper analysis required a deeper pool of data which was the purpose of 
collecting contact information from survey respondents. A total of 55 survey respondents gave their contact information and their permission for future contact. Seven people agreed to be interviewed. The results of these interviews and those of local experts in heritage are detailed in the next chapter. 


\section{CHAPTER FIVE INTERVIEW RESULTS AND DISCUSSION}

This chapter presents and discusses results from semi-structured interviews. Interview subjects fell into two groups: survey subjects and local experts. Interview questions were formed to further investigate visitor and expert attitudes about tour efficacy and heritage beliefs. The two groups will be presented and analyzed separately. Semi-structured interviews were conducted between October 2011 and February 2012. Seven interviews with Cliff Mine tour participants took place during this time. Nine interviews of local experts in the area of industrial heritage were also conducted at the same time.

I collected heritage beliefs among local experts through focused interviews to understand the variety of industrial heritage stakeholder groups. Their feedback on the Cliff Mine and issues regarding its preservation and interpretation was sought through these interviews. Local expert interviews also explored the role of tourism and outreach in the Keweenaw. The semi-structured interviews attempt to make sense of abstract ideas and assumed behaviors and beliefs surrounding industrial heritage in the Keweenaw (Sørenson 2009:166). Some interviews were conducted in person and others were conducted by telephone.

The Cliff Mine tour visitor interviews and their results are presented at the beginning of this chapter. Interviews with local experts follow the visitor interviews. Responses to questions asked of both groups are presented after the local expert interviews. In the discussion, stakeholder group memberships are assigned to both Cliff Mine visitor respondents and local experts. These groups were created based on visitation to the Cliff (visitor interviewees) and position in the community (local experts) to determine whether experience and identity can predict certain responses. The negotiation of individual and professional identities by individuals is also analyzed. The chapter concludes by synthesizing the data and presenting the values stakeholder groups express for industrial heritage in the Keweenaw. 


\section{Interviews with Visitors}

Interview subjects were selected from survey results based on the respondent's demographic profile. A053 and A094 were chosen because they represented a male and a female retired visitor who lived in the area at least part time. Both A010 and A070 were chosen because they were young but also because they had very different occupations and identities as locals. A027 was chosen because he was from another state and represented a working class occupation. A034 was chosen because she was a local female of an underrepresented age group and A092 was chosen because she was a part time local in a well-represented occupation. Only the interview data from this group will be discussed in this chapter.

Interview times lasted between 20 and 60 minutes each. Two interviews were conducted in person and five were conducted over the telephone. Responses were recorded on a digital recorder and transcribed into a word processor. The interviewees were given code numbers which corresponded to their survey numbers. Responses were then coded and organized, first by question and then by response type. The following section is organized by theme, addressing one question (and responses to this question) at a time. Responses to each question are coded by theme or subject matter. Visitor interviewee profiles are located in Appendix C.

\section{Lasting Impressions}

The first question asked of visitors in their interview was, "Since visiting the Cliff, have you thought much about your experience?" Leading with this question takes the interviewee back to their experiences the summer prior. This question was intended to prime the respondent to discuss their experiences in later questions. The responses were generally positive.

Interviewees A070 and A053 found the experience to be "cool" or loved going to the Cliff. In particular, one interviewee said, "It was one of the cooler things I got to do in the summer. It was one of the more awesome things I got to see, or if anyone ever asks me what are some of the cool degrees they have around here, I always answer, 'Oh, they have a really cool archaeology project, or program."” 
Three other interviewees said that they did think about their experiences at the Cliff Mine after attending the tour. A027 indicated a curiosity about whether or not tours would be offered again in 2012 and A094 had pulled up photos he had taken at the Cliff Mine to look at them during his interview. The last response in this group comes from A034, a repeat visitor to the Cliff Mine who had made her own tour booklet before going out to the Cliff Mine for the first time: "Yeah, I have thought about it. I think about this at home but I do not have access to the internet on purpose, to go look at [the site] blog and see what kind of work they are doing."

The last response indicates that the reason A010 had a negative memory of the Cliff Mine tour was because of the experience he had after his visit. This respondent indicated that after the tour, he was hesitant to bring family and friends to the Cliff Mine because he did not know if self-guided exploration of the Cliff area was legally allowed. "You almost feel like you are trespassing and missing a lot of things that are in the area because there is simply no good way to find out about them unless you start hanging out with people who have lived here for 30 years and know where all the stuff is," he stated. This respondent knew who owned the land but felt uninformed due to the lack of interpretive signage.

The most important finding from this question was that respondents remembered their experience at the Cliff Mine and offered, without provocation, additional thoughts about their visit. They valued the experience enough to easily recall whether or not they had thought about it in the months afterward.

\section{Heritage and Identity}

In order to explore if identity was tied to heritage as a concept, I asked, "How do you define/what do you think when you hear the word 'heritage'?" Because heritage was a familiar yet individualized concept, responses were distinct with an overarching theme of a cultural relationship to the past.

A094 said, "I think they use that term to cover a lot of things. I would be more towards industrial heritage though," indicating their preference. "Heritage would be basically the people or community that others may be related to or are sharing the end 
results of," was A027's definition. Respondent A070 said simply, "What was before and how it ties into you," which was very similar to A053's response: "What you have because of the past. Whether it's family or your location or places you like to visit, whatever." Finally, A010 said, "Probably cultural knowledge that is passed down. I tend to think less of genealogical ancestry but more like what kind of culture you grew up in." Interviewees overwhelmingly identified heritage as the past within their culture.

\section{$\underline{\text { Further Heritage Site Visitation }}$}

Another interview question inquired if interviewees were inspired to attend additional tours after visiting the Cliff Mine tour. Interviewees were asked, "Did your experience this summer inspire you to attend other historical sites or to seek out new experiences like the Cliff tour?" The responses were divided into groups based on the themes of their answers.

The first group consists of respondents who said that they took advantage of opportunities when they were able. A070 said, "I always have a general interest in the historical aspects up here, but it didn't increase my actual investigation into [history]. I am much more of an opportunist, so when I see something or have the means to get there I will go that day." A034 works a full-time job year-round and did not "have a lot of time to do that kind of stuff," but considered visiting historic mining sites a hobby. This respondent also indicated an increased interest in the "preservation cause" due to this hobby.

The second group included positive responses with some either agreeing that the Cliff Mine tour inspired them to attend more events or that they already attended such events or sought opportunities before the Cliff tour. A027 took "self-guided" tours and another said that because he lived in Wisconsin, the economy was a factor and he did not go on another tour.

One respondent disagreed with the premise of the question. Respondent A010 said, "Well, I think it is sort of the other way around. Going to other events like the Quincy Mine inspired me to want to see this mine," indicating that events in the Keweenaw supply one another with participants. Finding that tourist attractions and 
heritage sites in the Keweenaw tend to feed each other with visitors was very significant.

\section{Experience with Archaeology}

I asked, "Did your experience at Cliff change how you imagined or experienced archaeology?" Responses fell into two general categories. The first group acknowledged a change in their perception of archaeology based on their experience at the Cliff Mine. Two responses indicate that the physical experience of being at the site added a positive dimension to what A010 said came from "a book or on the internet." A070 noted that he did not understand why the site had to be reburied until he asked the crew on-site and this was what changed his perception of archaeology. This interviewee showed a strong interest in and knowledge of preservation technology.

The last respondent in this group said that the tour "definitely changed how I thought about archaeology in the Keweenaw." A093 indicated a curiosity in what the MTU Industrial Archaeology program was and what they did, only just discovering the goals and purpose of the program on-site. Coming from the East Coast, this respondent expressed a geographically specific understanding of historical archaeology. This was valuable to the respondent because of her connection to the Keweenaw, expressed in this quote:

"We would go copper-picking at old mine sites and not really know much about the history other than our grandfather who had been a miner and some uncles who were miners up there, but not really understanding how these things, there just wasn't as much interpretation and it wasn't easy to visualize what a stamp mill looked like."

The excavation provided a visualization of mining history that had value to this interviewee. This was an important finding because it validates on-site archaeological outreach when site interpretation includes visualization.

Another group claimed to have had previous knowledge of historical and industrial archaeology or had prior positive views and experiences related to archaeology. Of the three respondents, A053 indicated that she had "been involved in things like this before" and knows that "more recent history is done by other archaeologists," than Egyptologists or prehistoric archaeologists. AA094 indicated that he was a MTU graduate 
and has done research on industrial archaeology. The last respondent, A093, felt that the tour "reinforced a positive opinion" of archaeology that she had already had, mentioning the genesis of the field of archaeology and its early "abuses". She concluded by saying:

"A lot of people on the tour I know asked, 'Are you just going to leave this open', and there is a little bit of disappointment when, 'No, we have to cover it back up.' But they did a very good job of explaining why we have to cover it back up, because it will disappear forever if you don't cover it back up, protect it."

This respondent identified something very important in this quote. The field school students and tour guides on-site were able to convey the importance of the stamp sands as a preservative of the delicate wood that was uncovered.

\section{$\underline{\text { Feelings about Preservation }}$}

Interviewees were asked, "Did your experience at Cliff change how you felt about preserving historical sites (or did it reinforce how you felt)?" eliciting very individual responses. The first generalized category indicated that the interviewee's opinion changed a little, as in the first response from A053: "I think it is important stuff to do, it is kinda neat...I support it because if you don't remember the past you are doomed to repeat it." The other response in this category, from A027, felt "little" change and expressed concern about keeping the public involved in discoveries, saying, “... I am so leery about someone finding something and then they close it off from everybody permanently... I guess public involvement instead of it just being closed off and no one knowing anything but what comes out in a book."

Another group responded that they had already supported heritage preservation prior to their experiences on the Cliff Mine tour. A010 felt that knowing the local history was a boon to his experiences in the Keweenaw and A093 stated that it was because of her family history. A093 mentioned her membership in the $\mathrm{KCHS}^{8}$ and raised the issue of reburying the site:

\footnotetext{
8 The Keweenaw County Historical Society (KCHS) owns and actively preserves over 10 sites in Keweenaw County, including those at the historic Central Mine, and is an important local non-profit group. This group is also very interested in preserving the Cliff Mine.
} 
"It's not like seeing Cliff changed my mind or how I felt about preserving the sites that existed there, but I will tell you what one of my frustrations was. That insight into how that old structure looked, which was so well preserved because of the stamp sand covering it, my frustration was that it couldn't remain open longer for more people to view. I really felt strongly that way because it was closed up before many of my relatives were unable to see it. But I understand why it had to be covered up, it would probably disintegrate."

Again, in the above passage, A093 referenced the reburial of the site as important. She "felt strongly" because it was important to her to share the experience of seeing the excavation with her family and was not able to.

The last respondent to this question opined that archaeologists and heritage managers need to have a plan of action to save the truly important sites and to document them. This, A070 insisted, would assist in the debate on whether or not to "save" sites because, "There is just too much, I don't want to hold onto chunks of rust forever." This was an important finding, the common dilemma in heritage preservation about what to preserve and for what reasons caused the respondent to go beyond the premises of the question. He instead explained that both preservation and development need to occur in the area. The processes involved in preserving sites are not always transparent to the public.

\section{Exploration at Cliff}

The question, "When you were at the Cliff, did you explore other regions of the site?" was asked of the visitor interviewees to identify their level of interaction with the site. Rock piles for mineral collecting were mentioned twice, with A027 saying, "I just wanted to go back and crawl around and see what I can find in the rock piles. I was really shocked at some of the things lying around," possibly hinting at the amount of minerals still present in the poor rock piles. A070 explored, "[smokestacks] and a large rock pile hill, more recent foundations to cinder block and re-bar as well as massive cornerstones and artifacts," found at the top of the cliff itself.

Three respondents were very interested in the social aspects of the Cliff Mine and Clifton areas, exploring "the two churches [foundations]," and the "cemeteries...[because they] showed how hard life was there," in an attempt to better understand the social 
history of the Cliff Mine miners and their families. Three respondents had little experience exploring and were not familiar with the landscape outside of the area explored on the tour. Overall, functional places (that is, places where specific activities occurred) on a site are significant to experiencing heritage sites, based on some interviewee responses.

\section{Themes of Interest}

Interviewees were asked, "Are you interested in certain themes in heritage or industrial archaeology, particularly at Cliff?" which allowed interviewees to expand on their interests and explain what mattered to them at Cliff or other heritage sites. Interests included the social lives of miners and their families, technical aspects of mining, mining "booms," and the evolution of mining sites and operations.

A few key responses stand out from this question's responses, one of which addressed aspects of Cliff's history not discussed on the tour:

"It is interesting at Cliff because it was one of the first major settlements in the Keweenaw and most of these people were immigrants in a very hostile environment, you know, how did they live, how did they survive, how was it like for them? Certainly there were different classes even within the Cliff Mine area. People worked underground, poor working class families. [I am] interested in how [middle-upper class] women, who may have been used to life out East, how on earth did they perceive things and how did they build a community?"

This respondent (A053) valued socially-oriented histories and discoveries. In a similar vein, A027's response seemed more technically-oriented:

"I mean not only was there construction on the sluices and machinery of the mine itself but there must have been some interesting construction techniques... do we really know about how they built their homes and stuff, their outbuildings?"

This response, like the one above it, illustrates visitor interest in the every-day lives of those who lived and worked at the Cliff Mine and Clifton, connecting industrial heritage to social history. 


\section{Cliff Mine Importance}

In an effort to understand how some of the visitor interviewees value the Cliff Mine, they were asked, "Is the Cliff site important to you for any reason?" Responses ranged from personal to objective importance and fell into several response groups. The first two visitor responses, from A070 and A027, found the Cliff Mine of importance historically but not personally:

"If I remember correctly, it was one of the first successful investments into mining, but it was just neat to know how did things get set into motion, where did it come from? Outside of that, no, it's a beautiful location. If it prevents industrial or commercial development there, yes, keep it, because I like the U.P. as it is."

Two respondents had a personal connection to the site and recognized that connection in others. A053 said, "I LOVE the Cliff; whenever we ride toward it from Calumet we always go down Cliff Drive. It offers a thrill, pulls at the heartstrings." A093 found the Cliff important personally and also identified an aspect of the Clifton site that she found compelling:

"There is a little bit of a mystique around Cliff simply because it was such a thriving community for about 20 to 30 years and then, poof! It is just gone...I often do see cars parked along the highway and Cliff Drive. You can tell they are checking out the two cemeteries, that is always of interest to people."

The last two responses found the Cliff Mine to be important historically but also because of the types of mineral resources that were historically mined and can be found there today. A027 said that, "Knowing the year that they came out at, basically how they processed the material, kind of interesting and makes the specimen even more interesting because you kinda know the character of the people that found it, that is kinda neat." A094 had read a lot about the Cliff Mine but did not know that Cliff needed a stamp mill: "I know they mined a lot of 'mass copper' but where you guys were digging up a stamp mill; that was not mass copper, it was some kind of amygdaloid or something? They must have found a lot of ore with it."

An interest in the mineral resources has been a driving force for many of the visitors to the Cliff Mine. It was important that two respondents brought up mineral 
collecting as it remains an integral part of the present use of the Cliff Mine site. There are visitors who come to the Cliff Mine site solely for the opportunity to collect mineral resources, but as A027 indicates, they tend to care about the history of the site in relation to the mineral wealth.

\section{Conclusions on Visitor Interviews}

The visitor interviews show how visitors to the Cliff Mine value the site and what they took away as lasting memories from their tour experiences. Heritage had a distinct meaning to visitors which was an overall connection to the past through culture and personal experience. Visitors enjoyed learning about the combination of technological processes and social settings at industrial heritage sites. Heritage sites in the Keweenaw feed visitors from one site to another and the processes involved in preserving these sites are not always clear to the public. Outreach helps to inform visitors about the processes of archaeology and heritage management. It was also important to understanding how visitors interact with the mineral resources at the site and why. This interaction was an important draw to some Cliff visitors.

Visitors to the Cliff Mine tours felt that overall their experiences were positive and meaningful. Some did bring up negatives, such as the excavation closing after only three tour weekends, but visitors were generally satisfied with the explanation for this. The tour needed more information on what the archaeology team knew about the day-today lives of miners and their families. Many visitors mentioned the book Copper Country Journal, the diary of schoolmaster Henry Hobart who lived and worked in the Cliff Mine/Clifton community at the end of the Civil War (Hobart 1991). Accounts from this book might help visitors to connect to the Cliff Mine site on a deeper level than just the history of the site itself could offer.

\section{Interviews with Local Experts}

Interview subjects termed local experts were chosen based on their enduring connections to Keweenaw heritage. Additionally, they were chosen very specifically because they do value preservation and heritage and have a connection to the Cliff Mine 


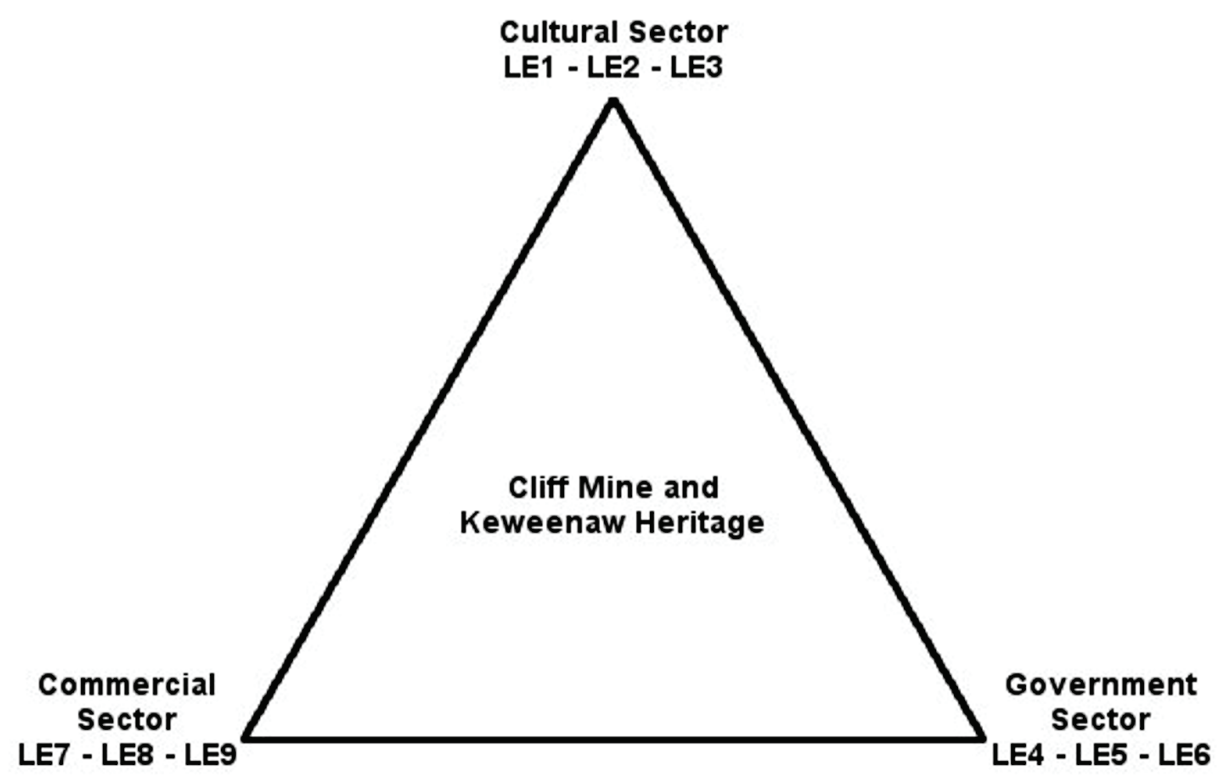

FIGURE 5.1: Local Experts are arranged into three groups for the purpose of this study; Cultural Sector, Government Sector, and Commercial Sector which are all involved in Cliff Mine and Keweenaw heritage (Illustration by the author, 2012).

property and history. Nine local experts were interviewed and represent three types of heritage stakeholders in the Keweenaw: the Government Sector, the Cultural Sector, and the Commercial Sector (FIGURE 5.1). Each group had three representative interviewees from varying positions within each group. These groups are not representative of every stakeholder group but are instead a sampling of these groups in the Keweenaw community. Local expert profiles are located in Appendix C.

Local experts who comprise the Cultural Sector group were: LE1, an educator and seasonal resident of the Keweenaw who runs a non-profit; LE2, a local retiree, Cliff Mine volunteer and current student; and LE3, a student and heritage professional. The name of this sector was difficult to sum up in a simple word, however, the word 'culture' works due to the nature of each interview subject's interests and employment which are within education and non-profits. This group was the most diverse of all the groups and was most strongly associated with researching and preserving the Cliff Mine. Two of these 
local experts were involved in ongoing research related to the Cliff and two were involved as participants in the Cliff Mine field school.

The Government Sector interviewees were chosen based on their employment, particularly because government agencies have specific rules and professed values on heritage and preservation. This stakeholder group consists of LE4 who was a government employee and heritage professional, LE5 who was the employee of a non-profit that is connected to a government agency and a local to the Keweenaw, and LE6 who was a senior quasi-government agency employee and also a student.

The Commercial Sector stakeholder group consisted of local experts whose primary employment and interests lie in small businesses and tourism. LE7 was a small business owner in the tourism industry as well as a former student and former heritage/museum professional, LE8 was a small business and property owner, and LE9 was a small business and property owner as well. What they all had in common was a financial investment in Keweenaw history.

\section{Experience with the Cliff}

It was important to establish if local experts had either visited the Cliff Mine or held knowledge about it. I asked, "Have you ever been to the Cliff Mine site?" LE5 had never been to the Cliff Mine but wanted to attend a tour. LE8 indicated that he had been to the Cliff Mine over 100 times. LE7 had been out on a tour of the Cliff Mine but did not find out about it until the last minute. Respondent LE7 said that the Cliff Mine is:

“... a perfect example of a site that's obviously an extreme, a huge importance to the history of the area and completely ignored...It's immediately accessible, I mean it's right off the highway where you could spit on it, unless you've lived here all your life you probably didn't have any idea."

This comment touches on a prior response made by a visitor interviewee, A010, about the hidden nature of some Keweenaw heritage sites. The feeling of separation felt by some visitors in regard to such sites was important because, as LE7 points out, some visitors were 'in the know' about such sites and people who were not from the area who may want to visit may have no idea how to or where to find such sites. A simple solution 


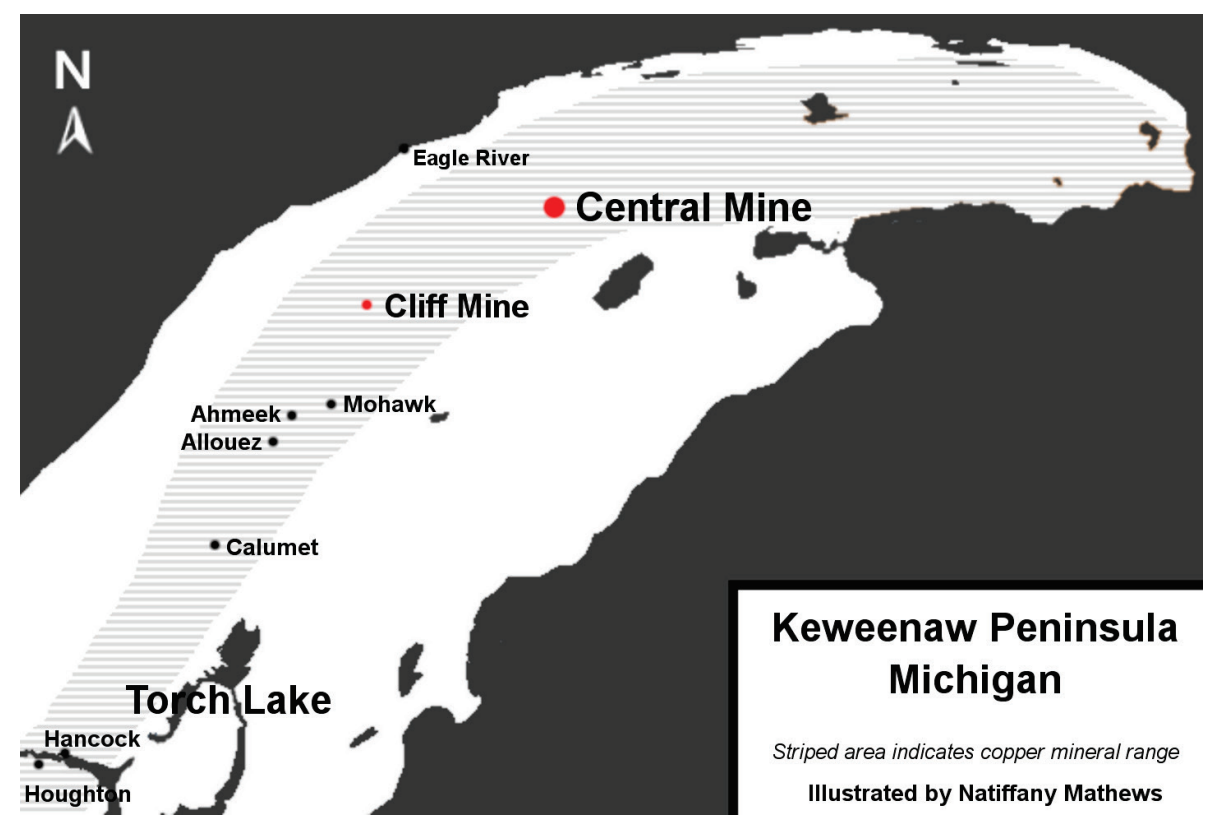

FIGURE 5.2: Illustration of the Keweenaw Peninsula, approximating the location of the historic Central Mine and Torch Lake Superfund site (Illustration by the author based on USGS data).

to this problem is wider information dissemination. This solution also creates problems, though, when it comes time to think about the preservation of such 'hidden' sites.

\section{$\underline{\text { Remediation }}$}

The Keweenaw Peninsula has had environmental remediation on stamp sands in several areas, including the Superfund site of Torch Lake and at the Central Mine (FIGURE 5.2). With such remediation perhaps looming on the horizon at the Cliff Mine, local experts were asked, "How do you feel about the environmental remediation that might take place at the Cliff Mine, or has taken place at other sites in the Keweenaw?"

LE9 said that the "Cliff Mine is one of the oldest mines in the area" and that the water near the Cliff, the West Branch of the Eagle River, was clean and had frogs and fish living in it. "In my opinion, I would not remediate it. I have seen a lot of the stuff they did around here on the stamp sand beaches, I don't think it's that effective." Sharing this opinion was LE8 who has seen science teachers test water that comes out of historic 
mines. "Most of these mines are mostly inert, there is some mine drainage with sulfides but those kinda break down in the environment."

Respondent LE2 had a problem with those who were certain either way. He did not think that "six inches of dirt on top of stamp sands" makes much of a difference when remediating. LE2 also stated that residents of the Keweenaw experience more pancreatic cancer than the rest of the population and that this phenomenon was "a curiosity." $\mathrm{He}$ would prefer more research to be done and said, "I'd like to be from Missouri, 'Show me,' eh? Give me some evaluation."

The only outright advocate of remediation was respondent LE1 whose family history was centered in the Keweenaw. She said:

"I also believe that at the historic mining operations, there was not [thought about] the environmental protection of the area and some of the activities have been very polluting. So I am actually very much in favor of restoration projects that are done with a sense of preserving the historic aspects."

So while an advocate of cleaning up the environment in the Keweenaw, this local expert was also personally tied to, and aware of, local preservation efforts.

\section{Keweenaw Preservation}

The next step was to find out how local experts felt about the preservation of heritage sites. Several local experts were asked, "What are your feelings about preservation in the Keweenaw? Do you think that all sites should be preserved, or do you take a more pragmatic approach and think that they should be selected based on how important they are?"

Most responses were, as expected, that the expert was pragmatic, such as LE5 who said, "I think I'm more selective." She mentioned going to see the newly renovated and interpreted Union Building and feeling that "this is really neat and we should do this." LE5 also said that while she has lived in Calumet her entire life, she did not know this building was in need of preservation.

Respondent LE3 said that not everything can be preserved and that it was the job of heritage professionals and archaeologists to make those determinations: 
"Of course you'd always want everything to be saved but that's not feasible. But if you can make determinations on what are the representative sites and put a lot of effort into those, the smaller, less significant sites might actually see preservation efforts because it gins up interest."

Respondent LE6 had many of the same sentiments as LE3: "You can't save everything and you shouldn't really try to save everything. You end up doing lots of things in a less than stellar manner as opposed to focusing on a few and doing it really well." LE6 indicated that in his agency, many decisions were out of the hands of local experts and were ultimately decided by government funding.

Respondent LE2 held that while there is not much money in preservation, the Keweenaw should be an important target for funding. "Unfortunately archaeology and preservation is not very glamorous, there are not a lot of dollar bills out there floating around, not like a lot of interesting things, and I think it's important to preserve this and interpret it." LE2 likes the Cliff Mine and nearby sites, Central and Delaware and feels strongly about the need for MTU to study these sites versus studying industrial heritage sites in other places in the state and nation.

\section{$\underline{\text { The Public and Preservation }}$}

Local experts were asked, "What do you think the public should know about preservation in the Keweenaw?" Their perspectives on this issue also provide evidence to the range of opinion in each stakeholder group. They might exhibit some bias based on business ownership, government employment, or education. Reiterating previous sentiments, LE9 said, "If you don't preserve, they go away pretty quickly, they just disappear." Particularly, LE9 said, waste products from mining are actively disappearing from the Keweenaw. Respondent LE8 emphasized safety at the waste rock piles on historic sites because people want to touch and climb. LE8 also said, "You are going to have people who are going to want to take something from the site all the time," so when limiting collecting as a part of a preservation strategy, there has to be a way to enforce the limits.

In advocating preservation to the public, LE6 said that, “....It takes people valuing 
their history and valuing what their history can do for them in the future. And so there are absolutely people in the community that feel that way, that are supportive of the history of the Keweenaw, but there are also a lot of folks who aren't." The local people who are not supportive have been a difficulty for heritage managers in the Keweenaw because they do not see the worth in restoring "old buildings," LE6 added.

LE1 had much the same to say, especially that, “...It's very important to help people make the link, because so many people have roots in the area, that the preservation of these sites is also a preservation of their heritage." She also mentioned projects that have been done before and may be seen again, such as the restoration and remediation done at Central Mine where there was, “...Some environmental restoration done at the same time as the human history was conserved. I guess the public needs to know that there might be those kinds of tradeoffs that have to happen and we have to work on satisfying both ends." So this respondent emphasized again that the environment was as important as the human heritage at Keweenaw historic mines.

Respondent LE4 felt that communicating the intentions of the preservation project was important, saying, "I think it's 'Why are you doing it, how it's being done?' ...it always comes back to, 'So what? Why are you doing this? Who cares?' Being able to answer that, being able to share that in a concise way with a visitor; this is why we're doing it." This would be accomplished through planning before preservation and interpretation on-site.

\section{Improving Tourism through Outreach}

After asking interviewees about the success of tourism in the Keweenaw, they were asked, "Do you think an increase in archaeological outreach or an improvement in public involvement would help tourism in the Keweenaw?" This question was intended to draw out opinions and insights about the activities at the Cliff Mine and to also ascertain if interviewees think that archaeology and outreach in the Keweenaw affect heritage tourism positively.

The first response group consisted of positive comments. LE9 continued to stress the importance of interactive, fun activities at heritage sites and said, "People like seeing 
real life things, I think people enjoy seeing archaeology done out in the open. People don't want make believe." Respondent LE5 said that archaeology projects were "neat" while LE1 mentioned that, "There is quite a base already of people who are interested in it, interested in that heritage. I think some more outreach couldn't hurt things," adding that she wants these sites open to the public. "It's not going to hurt," said respondent LE4, adding that people tend to visit the Keweenaw for natural beauty and the outdoors. “...But when they start to see more of what's around they start to become more interested and they want to extend their trips and stay longer," so these people become interested in heritage because it is something to do, which includes visiting sites and outreach projects.

Two interviewees did think that outreach would help tourism but were unsure of how it would affect the number of visitors to the Keweenaw. Respondent LE3 said, "I don't think at first it would necessarily improve as far as numbers. What it would improve is the public's perception." This was important, he said, because there are locals who consider the past to be over, that everyone needs to move on and that means not focusing on heritage. There was a concern that by doing outreach and archaeology that heritage will be removed as respondent LE8 warns: "There is a certain amount of local interest in that... I think with that, if you tell people where all the stuff is, is it going to go away?"

Respondent LE7 began by expressing frustration with the way local events were advertised, saying:

"I'm into history, I'm in to archaeology, not to make a career out of them, and yet so many things are happening here I don't find out about 'em until a week after. If I live here, I'm interested in it, and I don't know about it, how can we think someone driving into the area for a week would to know about it?"

LE7 felt that there should be more networking and communication between all heritage sites and tourism-related business owners. Back to the question at hand, he said that archaeology and outreach could only help, that he, “...[Doesn't] know if anybody was surprised at the interest in the Cliff projects the last couple of years," because it was such a unique opportunity in the Keweenaw to experience archaeology and heritage. 


\section{$\underline{\text { Future of the Cliff }}$}

Interviewees were asked, "What does the future look like for the Cliff site?" This question gauges how they see the Cliff's potential for being "saved" for preservation or not. A majority of the local experts seemed to see the Cliff Mine (and Clifton) properties as being in ownership limbo with many possible outcomes for the future of the site. The current owner, the Keweenaw County Road Commission (KCRC), has refrained from utilizing the site's poor rock piles for gravel and pavement fill so far. It was not certain among some interviewees if the KCRC would remain the owners of the Cliff Mine site for much longer or if other organizations were interested in buying it. Respondent LE9 saw the future of the Cliff Mine being preserved as a complementary site to other heritage destinations because:

"I see it as being a sideline to other areas up here. Except for the rock piles, there is not a whole lot there. I see it as being nice hiking trails, a nice place to go visit and see rock piles, to see foundations, but it is not going to be a big tourist draw. But I think it should be preserved, it's one of the oldest mine sites and one of the most profitable ones, I think it is a big part of the history."

As a business owner in the tourism industry, LE9's perspective on the profitability of the Cliff Mine site was important. Successful tourist attraction owners can be of assistance to preservationists in creating a well-attended site.

Respondent LE8 said, "I think that is a good candidate for preservation because it was one of the first early mines up there. It is easily accessible." He also wanted to see an area where collecting would be allowed on the preserved site. LE2 said that the future of the Cliff "looks good" but that, "...We have to figure out who is going to own it and if it is going to be a governmental agency, well a governmental agency [KCRC] owns it right now but they're kind of, they want to use the rock piles and we'd like to see the rock piles preserved." He mentioned the KCRC as owners because they bought the site with the intent of removing the poor rock piles to use as pothole filler or another road related use.

Respondents LE3 and LE7 expressed concern about the future of the Cliff Mine. LE3 did not see the Industrial Archaeology program at Tech researching the Cliff Mine site for longer than two more years. He did mention that "the NPS, in conjunction with maybe the Keweenaw County Historical Society" could purchase part if not the entire 
Cliff Mine site but that the site would have limited interpretation. One of the issues both LE3 and LE7 worried about was the planned remediation of the stamp sands at the Cliff Mine.

Respondent LE7 was especially concerned because he imagined "stuff disappearing every year," to make room for "more restricted access, more intrusion, and more growth." His strongest concern was with mining companies restarting operations in the Keweenaw:

"What does that mean, if you don't think about it now then it will be too late once they start. And people here need to think about what they want and expect out of something like that and sooner rather than later, you know? People I've talked to that know about things like that, they say there's no question about if they will ever mine here, it's a question of when will they mine here."

As there is an increasing conversation about mining operations resuming, LE7 would like to see the discussion moving toward what these companies can do to lessen the damage on the environment and unpreserved heritage.

\section{Conclusions on Local Expert Interviews}

Most of the local experts have definite opinions about the Cliff Mine and its future. Those in the Government Sector were the most optimistic about the Cliff Mine and see it as a part of the larger interpreted landscape. They also had the most restrictive attitudes about mineral collecting and thorough ideas about interpretation at the site. LE4 and LE6 had detailed ideas about the tourism potential of the Cliff, particularly as it relates to other sites and outdoors tourism. LE6 was also very clear about how the government sector funds their preservation projects. LE6 also said that such projects were worth the money the government spends on them because people tend to return to the Keweenaw year after year, connecting the local economy with industrial heritage sites.

The Commercial Sector respondents did not see the Cliff Mine having a strong commercial draw but to them, the unique nature of the way the Cliff exists now makes it an ideal place for limited interpretation. Their ideas about the future of the Cliff mine were very non-obtrusive such as marking a trail system and placing light interpretive signage. They felt that action needed to be taken soon to preserve the area, fearing that it 
was being chipped away.

The Cultural Sector had scattered opinions on nearly every question. LE1 was for remediation, LE2 undecided, and LE3 against. All three were very involved in the Cliff Mine and Clifton through tangentially-related groups or interests so they all know that the site was in jeopardy. They felt strongly about preserving the site in an uncluttered way and they frequently reiterated that it should be preserved. LE3 was concerned for the site and felt that the site would remain as it has been into the future. All of the sectors were fairly positive when it came to improving tourism through outreach.

\section{Visitor- and Local Expert-Answered Questions}

In the next section, visitors and local experts answer some of the same questions and blur the boundaries of their respective stakeholder groups. Some of the interview questions overlapped between the two groups. Asking both groups the same general questions allowed a comparative analysis to be made. Each group's answers were presented then compared and/or contrasted.

\section{Mineral Collecting}

Mineral collecting at the Cliff Mine site was valued in many different ways but activities like this have caused concern for heritage professionals. It was important to understand how interviewees perceived this activity, or engaged in it as a part of heritage. That led to asking the question, "Many people who visit Cliff collect minerals from the rock piles. Is this a part of Cliff's heritage along with historical mining?"

Respondent A070 said, "I don't know how significant it would be, significant that it happened, but again if it didn't happen, what else would have happened?" The mineral collecting that has happened at the site happened and constitutes heritage, but as the respondent alludes to later, it was not right or wrong and just "is." Respondent A093 recalled collecting as a child, saying:

"It certainly has a history, rock collecting and mineral collecting, but I am not sure how that fits with conservation of these old mines. Although, most of those things are found on [waste rock] heaps...I kinda have mixed feelings, I feel one way about people going in and collecting mineral specimens, but a little bit differently 
about, and I am sure I did this when I was young, picking up old nails or pipe stems, I feel differently about picking that stuff up...There may be degrees of control [in rock piles], I don’t know."

So while A093 engaged in this behavior in the past, she understood how this activity could be damaging to historic sites today.

The next group of visitor responses indicated that they were mineral collectors themselves or that damage from mineral collecting was not a big concern to them. Interviewee A053 collected minerals, "wherever I go, really," because the minerals remind him, "of place, doesn't cost money." Minerals became souvenirs to A053 which was a similar response to that of A027 who said that it was "nice to have a little collectible with you, you know?" A027 feels connected to the history of historic sites through mineral collecting. A094, who displayed copper on his mantle, finds minerals in his driveway which was graveled with poor rock. A010 felt that collecting has a heritage, adding that restricting collecting would, "make a lot of people unhappy." This is an important point; A010 believed that collecting is a part of local culture and that restricting this activity would essentially be an attack on the culture.

One of the most interesting responses in this group comes from respondent A034 who sees a problem in how historic sites manage their poor rock piles:

"My feeling is that there are certainly enough rocks out there, it is not like we are going to run out of rock. I don't see it as a problem. It is certainly a part of the culture...I find it kind of funny that Quincy [Mine Hoist Association] doesn't allow anybody to take their rocks. There is a big huge sign up, don't take the rocks, it's a part of a historic site. They're just rocks, but yeah I think it is something that should be, I don't think it should be prohibited. For some people, it is a door, a way for them to learn about what is out there, even by accident."

The emphasis at the end of this quote offers an insight into how some people view mineral collecting. Comments from mineral collectors in response to this question reflect this idea as some feel connections to historic sites through mineral collecting.

Some of the local experts responded positively to the question of mineral collecting representing heritage at the Cliff Mine. Others felt that there was a line between artifact collecting and mineral collecting or that restricting mineral collecting would be a bad decision. Respondent LE2 was an advocate of consumptive uses of sites, 
saying, "Consumptive use would probably include mineral collecting and I think if someone bought up the Cliff Mine and said 'thou shalt not hunt any more chisel chips' then there would be a lot of unhappy people." LE5 gave a positive response to the idea that mineral collecting has a heritage but also mentioned that her organization restricts collecting on their property.

Avoiding addressing the heritage of collecting, respondent LE8 said that, "The [collectors] that we have problems with are the semi-professional people who think they are going to make a living digging huge pits and holes and they really don't have an interest in the history, they're just looking for...money," and indicated that he has had problems with these collectors trespassing on his property and stealing. LE9 also made comments that were very similar:

"The locals up here, and there is a very small percentage, the locals up here, a lot of them have the attitude that the old mines have been there forever, we don't care who owns them, we don't care if it's historic, we don't care if anybody else cares, we are going to steal something anyways."

These comments indicate that historic property owners have a problem with a minority population of trespassers and collectors.

The final respondent in this group, LE7, had "no problem with it" and considered mineral collecting an ownership issue. "It's like dumpster diving or something, as long as it's safe and you're not going to sue me then, I don't want it anymore and you're welcome to it. So I personally don't have any particular problem with that," he remarked, while also commenting on the necessity of restricting rock piles when preserving an area.

Both groups cautioned against restricting mineral rights; to a point. Respondents from the local experts group, particularly those who own property or work in government agencies, were more likely to be against mineral collecting at sites like the Cliff Mine. Local experts identified a minority of the mineral collecting population who posed a larger problem than the rest.

\section{Preserving the Cliff}

Knowing how survey interviewees and local experts would actually go about 
preserving the Cliff Mine site was important as these are the people who visit and would potentially make preservation decisions at the Cliff Mine. They were asked, "If you could do anything you wanted and money were no object, how would you preserve the Cliff site?" Survey interviewees and local experts were supportive of preservation and local heritage overall but had different ideas about what should happen at the Cliff.

The first visitor group indicated that extensive preservation and interpretation would be needed, such as building reconstruction and interpretive signage. A094 responded, "It would be nice to be able to preserve the entire stamp mill so you wouldn't have to bury it again," and indicated a desire to see more of the site interpreted. A027 had an idea for interpretation from the Badlands, suggesting, “...they have areas that are excavated and are covered with Plexiglas to where you can have a walking tour, that kinda thing." He also indicated that he would like to see a section of the site set aside for collectors. Respondent A053 simply wanted to, “...find all of the workings that are possible," and possibly interpret and rebuild buildings on the site.

Two visitor group respondents felt that the site should be documented fully to learn everything possible and to reconstruct the site digitally. A070 added to their concept of a 3-D model of Cliff by saying, "Preserving it? Well the only problem is that, after you know, dig it all up, it would be so cool just to see everything. Then either choose to keep it or get rid of it." Respondent A034 also described a digital environment that she would want created of the Cliff Mine through research but also added that the Cliff was:

"...One of the only places I can honestly say that I have been to in the Keweenaw that gets a fair amount of traffic that has no trash, no garbage lying around. I don't know if anything necessarily needs to be done there... You know, the earth does repair itself from all of this and this is what happens when a site is neglected. There is an educational aspect to that as well."

Respondent A010 remarked that if he were given money to preserve the Cliff, he would put some of it into promoting the entire area. "People who live in the area would know through a sign or welcoming direction would know that this is an example of a mining site so that when they get there," and the tours would be largely self-guided. A093 went a step farther, adding a trail map, interpretive signs and a small greeting 
building, saying, "I was glad to be able to see what was under there, under the stamp sands and stuff, the excavation, but it is nice to have it be less touched."

Another group of responses, this time from local experts, saw a full archaeological survey taking place so that the site could be fully researched with everything about the history documented. Respondent LE2 suggested buying the property first and then having a "huddle" with the Social Sciences department at MTU, “... see what we can generate on the Cliff and when we run out of research projects... sic them on Central [Mine], work with the KCHS and sic them on Delaware [Mine], work with the guy who runs that place and interpret the living tar out of this place." In a similar vein, respondent LE8 suggested other mines to preserve first such as the Minesota, but if it had to be the Cliff, he would want a "big archaeological survey first" as the Cliff was "one of the richest [copper mines] that ever was."

The last response group, and the largest, would like to see minimal interpretation, such as non-obtrusive signage, and to essentially leave it as it was. LE7 added that technology could replace signage and interpretation:

"When I go to a museum, if you have a label that has more than 3 lines I'm not going to read it, I'll read a caption on a photo if it catches my eye but you're limited on how much you can put in there. On another hand, I'll come across something I get interested in and there's only 3 sentences."

A solution to this problem is technology, such as quick response (QR) codes. Smart phone codes were also mentioned by respondent LE4. About the act of interpretation, she said, "I think sometimes just through observation and through the process of what you're doing it can get people thinking and often...the result you're looking for doesn't happen right away. It's multilayered, it's not any one set solution," but LE4, like the other respondents in this group, felt that the Cliff was best interpreted with minimal impact.

Respondent LE6 advocated a multi-faceted approach to preserving the Cliff Mine by using the tourism industry and advertisements but interpreting the site in a way that, "...you're leaving the trees, you're leaving the reclamation that has been done by Mother Nature of the site. So that you're not trying to recreate what was there, you're trying to explain what went on and yet still allow for the natural use of the place." The Cliff Mine, 
LE6 said, was already a multi-use site and can accommodate even more uses or more of a presence in the outdoor tourism industry.

LE9 also mentioned trail signs and with color interpretive signs along the trails. He also said, "But I think I would restrict mineral collecting there," as it would be distracting and damaging to the site. Respondent LE3 emphasized how inexpensive their ideas for the Cliff Mine would be saying:

"I'm all for tour guides and things but in the end I think people should experience it on their own, the way I first experienced it. So having it all whiz-bang and everything is just told to you without you having to kind of figure it out is not as good."

Respondent LE4 had been on an unofficial tour of the Cliff Mine and felt that the site should retain its character, that buildings and reconstructions not be built there because, “...otherwise you start to miss things that you're not even noticing on the landscape because you don't even know the story." In terms of interpretation, LE4 said, "I think [there] could be just large interpretive wayside panel at the beginning that maybe has a map highlighting some of where things were."

Both the visitors and local experts mentioned interpretive signage as a part of the preservation strategy at the Cliff Mine. Two respondents, LE7 and LE4, mentioned QR codes and downloadable information that visitors could use while they visit the Cliff site. As a solution to intrusive interpretive signs and reconstructions, local experts believe that utilizing technology may be a viable step in retaining Cliff's unique character under a preservation strategy. In contrast, most visitor interviewees idealized the preservation of the Cliff as a heavily interpreted and researched heritage site.

\section{$\underline{\text { Tourism as an Industry }}$}

Most of the interviewees, both survey-takers and local experts, were asked, "Do you think tourism in the Keweenaw is a successful industry?" Seeing tourism as an industry from a consumer point of view might be different from the point of view of a business owner or heritage manager. Respondent A093 felt that tourism "is a really vital part of going into the future in the Keweenaw." A093 sees the growth of tourism 
providing a new identity for the Keweenaw. A053 and A010 had many of the same comments that A093 had, that tourism was vital, successful, and increasing in relevance as an industry.

Respondent A027 mentioned a necessity for advertising and promotion, saying, "...This is an area that is word of mouth. You discover things through word of mouth," which, he said, was one of the good and bad aspects of Keweenaw tourism. He felt that many other areas of the state of Michigan were advertised except the Keweenaw.

However, the story of the Keweenaw was told extremely well according to A034: "I don't think people even realize how lucky we are to have all these different sites, which may or may not even work together or talk to each other but it presents a very full picture." Educationally, A03 said, the tourism industry was successful but not yet in an economic sense.

Respondent A070 continued this idea and said that there was a passionate but small group of people in the country who are interested in this type of industry-based tourism, that it "is not a "whim"” to visit the Keweenaw because it has to be sought out. "It is as successful as far as I would care for it to be successful," he added. A094 also indicated that industrial heritage tourists are a small and curious minority. "You look at the people who go there and it's kind of an unusual bunch." This, A094 said, was tied to the fact that there is not much money to go around in industrial heritage tourism and preservation. When mentioning the state of several large pieces of machinery that were rusting away in the Keweenaw, A094 said, "You can only do so much I guess."

The local experts had strong ideas about Keweenaw tourism. Citing business owners who own hotels and restaurants as examples, respondent LE6 considered tourism to be the third largest employer behind MTU and the area hospital. LE6 had suggestions, as well:

"We need to be concerned about marketing and tourism and how we get people from Chicago, Detroit, Milwaukee, Green Bay, to want to come here so that not only can they learn about this story but also so they can support all of these other important partners and help them survive."

When I asked LE6 if outdoor and casual tourism were larger draws than heritage tourism, 
he said that, "...If we can get those people and give them something to do while they're waiting on the boat to go to Isle Royale or in between bike races or whatever, then we've widened the appreciation of this place." Later in the interview, LE6 mentioned the combination of outdoor interests with heritage sites, a niche the Cliff Mine would fit into.

LE4 went beyond this idea and said that from their experience, visitors to the Keweenaw have "nothing but really positive things" to say about their visits. "You still have mom and pop hotels operating and there's a sense of liking that, so yes, I would say it's successful," LE4 added. In her experiences while employed in a government agency, she has noticed that people tend to fall in love with visiting the Keweenaw and that those visitors tend to come back year after year. LE5 considered tourism in the Keweenaw successful and vital. She also said that tourism has an increasing presence in the Keweenaw as a strong industry.

There were those who considered the tourism industry in the Keweenaw successful but felt that it could be even more prosperous than it was. Respondent LE7 remarked that, "There's so much that could be done to make it more successful it could be much more stable, could be much more year-round." An additional complication, said LE7, was that the Keweenaw lies so far from the "core audience" of tourists that it was hard to advertise to them. There is a geographic separation of the Keweenaw and Upper Peninsula to the rest of the country but also a uniqueness that draws visitors. "People come here for two reasons: one is outdoors and the other is history and usually it's both," so, LE7 insisted, there should be a common ground to find to encourage tourism and preservation.

LE9 believed that tourism in the Keweenaw is a success but needs to update itself to cater to tourists. For instance, LE9 says, "We're really trying to focus what we are doing to what the public wants and if the public wants longer tours, we cater to what they want. If they want this, we will do that." He then cited Disney as an example of an interactive and dynamic tourist experience in contrast to the "traditional museum" model favored in the Keweenaw. LE9 also believed that, "...We [those in the tourism industry] need to be historical entertainers," because people need to enjoy their experiences to spread the word, return to the Keweenaw, and bolster tourism. 
Respondent LE2 espoused the view that tourism in the Keweenaw has yet to reach its full potential. "I think there's tremendous potential for this sort of thing," he said, also adding that he had a friend who provided tours of the Keweenaw. This friend would take people on personalized tours anywhere they wanted to go, which LE2 believed has a lot of potential if it can be tied into a larger presence in the Keweenaw, such as the NPS. "I don't think we've scratched the surface," he reiterated.

The final response group felt that the tourism industry in the Keweenaw was successful for what it was and that it filled a niche. LE3 believes that outdoors and sports tourism had a broader appeal in the Keweenaw than history and that there was a stark division between the two types of tourism in the area, saying, "I see a big division because there are quite a lot of people who come up here for the kayaking, biking, snowmobiling, who could care less about the history stuff. I think that that part of tourism up here does excellent." There was, LE3 said, a specific type of tourist for heritage sites, making this branch of tourism less successful when it could do "much, much better."

Visitor interviewees tended to have a positive view of Keweenaw tourism as an industry, possibly because they were engaging in that industry. Local experts were more critical, particularly because their livelihoods depend on tourism as a success and as a large industry. The most emphatic responses were those that posited that tourism needed to be more successful and grow.

\section{Locality}

Selected interviewees were asked, "Are you local or non-local to the Keweenaw?" For local experts, this question was asked to gain a perspective on their identities and relationships within the community. Because locality is part of an individual identity, everyone responded differently when asked, however, one theme stood out in many of the responses. Interviewees identified that they were either non-local or local dependent upon how they felt toward the area rather than by their birthplace.

The only respondent to indicate that one does not need to be born in the Keweenaw to be considered a local was respondent A070. "I am only local as of the last 5 years," he said, "Local enough, I intend to live here for the rest of my life, that is the truth 
of the matter." He felt that a person can earn their localness. Another respondent who moved here in grade school but considered herself local was interviewee A034 who said, "I had options to leave the Upper Peninsula many times but I decided I did not want to. Part of that is that I like small town living, rural living. Part of the draw, too, is being so close to the unique history." She loved the fact that there were so many museums and heritage sites in the Keweenaw as opposed to other places in the Upper Peninsula.

Both A027 and A010 identified as non-locals. A027 lived in another state and was at the Cliff Mine tour to collect minerals and learn about archaeology. He had only, “...Discovered the area about 8 years ago. In order to collect things, you need to study the history to find specific minerals. That is how I got into it." He had met many locals and had found a way to connect to the Keweenaw without identifying as local.

Respondent A010 has "only lived here 2 years" and does not "know much about the area" so identified as non-local. He also indicated that you cannot be local without being born in the area.

Respondent A094 was another self-identified non-local who owned a house in the Keweenaw and has visited the area every summer since retiring. He felt that his situation was "complicated" because he lives six months of the year in Indiana and six months in the Keweenaw. A094 also said he did not "feel like a stranger anymore" and felt like he was learning the area well, saying, "I have gotten to know a lot of people so I kind of feel comfortable up there."

A similar environment can create localness according to respondent LE3. He came from a culturally and environmentally similar environment in the Northern Midwest, so it was easier for him to relate to local people in the Keweenaw. While LE3 does not consider himself local, he did say that:

“...This is my seventh winter here and I am engaged to a local and I spend a lot of time with locals, so I am a local transplant in some ways. I feel very local in many ways. I care about the local, I can't think of myself of an outsider too much, but I am from the Upper Midwest, so I think I have a lot in common just from some cultural standpoint."

"I actually wasn't born here, so technically not. If you're not born here you're never a local, you never 'get in'," said LE7, who moved to the area in grade school and 
went on to describe himself as being local anyhow. As a heritage professional-business owner and a self-described local, he felt that he was unique in the area, saying "You can find plenty of local people - you can find plenty of professional staff and historians in the area. But you find very few locals with a professional background."

Even though he moved to the Keweenaw as an adult, respondent LE2 has been here for "50 years," saying of his locality, "All these locals had to have come from somewhere, well I came from Lower Michigan but I pretty much throw my allegiance to the Copper Country. I like to think of myself as a local." He still had problems being accepted as a local by those born in the Keweenaw because of his affiliations with a government agency. LE2 said that many local people saw this agency as a "black mark" on his forehead that he can never wash away.

\section{Creating a Local Identity}

After establishing locality, interviewees were asked, "What makes a person local to an area, particularly an area like the Keweenaw? Can someone become local?" This question was asked in effort to understand how identities of locality are constructed within a social context and how respondents might react to that based on how they selfidentify.

Respondent A094 said, "I don't consider myself really local but I am learning," and that he would "get there" one day. A053, who identified as local, said what makes a local is, "... Someone who either lives in the area; they do not have to be a native, just moved there of free will." However, she also mentioned that a person cannot be a nonlocal of the area they were born in or grew up in.

Spending every summer of their entire life in the Keweenaw may not be enough to be a local according to A093. This respondent said that, "Even though seasonal people can integrate into the community, I don't think it is quite the same." Not experiencing "the brunt of a true Keweenaw winter" separated her from true localness. A093 even had family who live in the area as locals but she herself could not be considered one. As far as how she felt about their own identity, A093 said, "I think this [Cliff Mine tour] makes me more of a local... I kinda feel like I am local because I have been here every year of my 
life."

The last visitor response comes from a self-described local, respondent A070, who indicated that many people identify what separates them from other people instead of focusing on what unites them. A070 also said that he would "determine local as, what do you do for the community, what does the community mean to you? Are you attached to the location, the school, or anything else?" About those who had a difficult time deciding their locality, A070 said:

"You're asking people to say what matters to them. In my answer, I said, 'Where do I live, I live here. Where do I intend to live, here. Where do I work, here. Where do I intend to spend my money here, where do I intend to improve [myself], here.' I am dedicated to this area, I am interested in local politics and local development and everything else. Not just, ehh, if it happens it happens. That is why I consider myself local."

Localness is a strong aspect of identity, especially for A070 who had spent a lot of time thinking about his identity as a local.

Local experts had many of the same things to say about locality. LE5 said that someone who wants to be local can "live here whatever amount of time, and get involved, and love it, and there's people that have lived here for a few years that are more into everything, more than people that were born here." LE5 emphasized an involvement in community activities as a way to earn locality. Respondent LE2 said that he was local because he "think[s] it grades into localness" after time. LE2 also mentioned that after someone has been here long enough and seen and learned enough things that they can "interpret" the area like a local can. However, he did add, "I think it's pretty cut and dry what is a local; if you're born here then you're a local."

LE7 believed that locality was something a person was born into, from a social perspective:

"You know, you can't, that's a fraternity you really can't get in, you either were or you weren't. And I do think there's a difference if you're not. There are names, and we don't have one of the great Copper Country names, so I can't trace myself back to the [early occupation of the Keweenaw]."

For LE7, identifying as local creates authenticity with visitors from other communities 
who want to patronize locally-owned businesses run by experts.

LE3 believed that, "Up here, people will never see me as local. Never. Never ever. I could live here for 60 years. That's actually what I like, I kinda like that." LE3 also mentioned that people can leave the area after being born or raised here but that they will always be local and welcomed back. Respondent LE3 would have really liked to consider himself local and certainly identifies as a local, but felt that many local families have strong ties with other local families and LE3 cannot be part of that, even when he has married into one of those families.

Respondent A070 was right; this question did ask the interviewee to divulge what mattered most to them. Most respondents identified as local or non-local based on how they felt about the Keweenaw and not on where they were born. Many of the local experts resisted what they believed other people identified them as because they felt that they were truly local. They identified as a local because they value their community and they want to be a part of the community as a local person. Visitors also felt this way about living in the Keweenaw; locality can be earned even if there are people who will not accept that person as a local.

Identifying as local to an area was important for most of the interviewees. Their thoughts and ideas about preservation and heritage were weighted with the degree to which they felt they were local. Even so, those who identified as non-local still felt that they were creating connections to the Keweenaw and its industrial heritage sites through visitation, becoming "more of a local" in the process. As LE7 mentioned, identifying oneself as a local creates authenticity to non-locals. Self-identified locals include themselves in local politics and events, building their identities up as people who belong to the locale instead of existing in a location. Visitors also had emotional experiences that connected them to the site, a numen (2000:110) experience according to Cameron and Gatewood.

\section{Visitor Interviewee Conclusions}

From the interview responses, several distinct stakeholder groups emerged. These groups had a similar interest in common, which was the valuing of heritage, but differed 
in several key areas. Group membership can be fluid and change but delineating between groups was necessary for understanding the positions members hold within them. The survey respondents who were interviewed fell primarily into two of these stakeholder groups.

The first group that emerged from interview data were 'Visitors,' people who value being able to visit sites like the Cliff Mine and had at least a general interest in Keweenaw history. This group scaled along a spectrum from the Casual Visitor, those who had a general interest in either history or historic sites and had been to the Cliff once or twice, to the Repeat Visitor, interviewees who had a strong interest in history and had been to the Cliff site more than once. Of the interviewed visitors, there were more in the Repeat Visitor group than in the Casual Visitor group.

The Casual Visitors were the stakeholder group easiest to identify. Casual Visitors generally visit industrial heritage sites for the consumption of history, specifically local history. They did not know much about the site before their visit but seem willing to engage in learning about the Cliff. There was a sense of alienation between being nonlocal versus local for some. However, both local and non-local respondents felt an increased sense of connection to the area through industrial heritage. Casual Visitors did not have strong feelings about mineral collecting and seemed unsure of how it should be regulated, if at all.

Among Repeat Visitors were those whose primary motivation to visit industrial heritage sites were either mineral collecting or the exploration of history. Most of the visitors in this group were part-time residents of the Keweenaw and tend to visit the Cliff Mine every summer. Some of these repeat visitors were "niche" tourists who visited industrial heritage sites for specific reasons, such as mineral collecting. Mineral collectors in this group were adamant that the site be kept open to this activity and to the public at large. Repeat Visitor interviewees had specific places at the Cliff they remembered as meaningful. They also had an interest in seeing interpretive signs at the site to mark specific areas and had a connection to the area.

There was one contradictory belief that emerged from the interview data. There were some interviewees who wanted to keep the site open to collecting and to the public 
but also wanted to see the site preserved and interpreted. Whether or not the two ideas were at conflict in the respondent's minds, this was a common response among mineral collector hobbyists at the Cliff Mine site. Mineral collecting was what brought some of the respondents to the Keweenaw in the first place, creating a complicated relationship between the areas of tourism, collecting, and preservation.

\section{Local Expert Conclusions}

Local experts represent different stakeholder groups within the heritage community. All local expert stakeholder groups share preservation values, but sometimes their methodologies for conducting preservation play out differently. Various organizations that local experts may belong to have diverse philosophies on how historic properties are interpreted or preserved, influencing how each expert idealizes preservation efforts. Altogether, every local expert that was interviewed has a perspective which relates directly to the Cliff Mine and heritage. Their profiles can be found in Appendix C.

Local experts were chosen very specifically because they do value preservation and heritage and have a connection to the Cliff Mine property and history. All of the experts were concerned with not only the local community but with issues involving property ownership, specifically public access and privatization, and how sites can be preserved and interpreted. While they have similar interests, their solutions to such concerns fall in different spots on the landscape of heritage management.

Stakeholders in each of the three groups actually overlap into other groups but were organized by their strongest identity for the sake of simplicity. Each individual plays multiple roles within the community, such as LE9, who owns a business related to tourism and works with a governmental agency. This respondent was also a former local so was connected in some way to the Commercial, Government, and Cultural Sectors. LE2 worked in the Government Sector; after retiring, his primary identity was with the Cultural Sector as a student and member of various non-profit organizations. Each sector feeds into each other (FIGURE 5.3) and expert identities also flow into multiple sectors.

In the Cultural Sector were three respondents; LE1, LE2, and LE3 who were each 


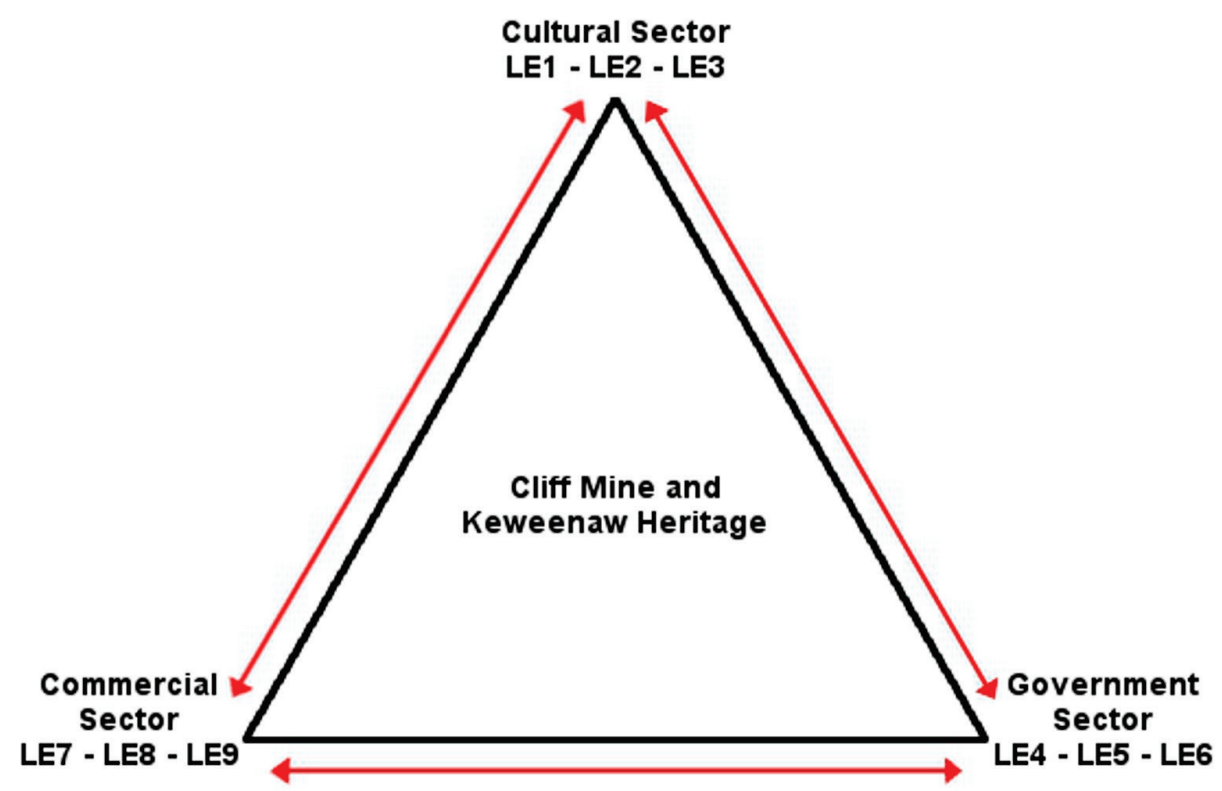

FIGURE 5.3: All Local Expert groups (Commercial Sector, Government Sector, and Cultural Sector) cross boundaries of the sections when individuals navigate their immediate identities (Illustration by the author, 2012).

invested in the Cliff Mine's future. LE3 was pessimistic about how the Cliff would be saved but LE1 and LE2 saw good things happening, namely the preservation of the site. They had all been involved in local non-profits, LE2 more than the other two, so they all saw the importance of heritage but not at the cost of restricting access to local people or of sacrificing the environment. All three interviewees in this sector negotiated their local identity in the same way: that being that they were not born in the Keweenaw but identify as local people.

Interviewees from the Government Sector, LE4, LE5, and LE6, had many roles to play in the community. LE5 was a local-born employee of a non-profit that assists a governmental agency and was a lifelong resident of the same local town. The other two in this sector had both been students, but LE6 was a current university student in addition to having a role in a quasi-governmental agency. They're all concerned with not just preservation but the interpretation of heritage in the Keweenaw. Public outreach was an 
important factor in gaining allies to their cause but they were clear that there was often local opposition to, and confusion about, preservation projects.

LE6 and LE4 were directly involved in such preservation projects. Being employed by connected government agencies, they both had unique perspectives on preservation and heritage management in the Keweenaw such as their mindfulness of public accessibility and the marketing of heritage sites. They were very aware of the necessity for public involvement in heritage management. Like other local experts, they both valued and recognized the importance of the Cliff Mine and had ideas for how to interpret the site, but as a site within a Government Sector framework. They were both aware of the current state of the Cliff Mine as a threatened historical site.

Local experts in the Commercial Sector, LE9, LE8, and LE7, were business owners in the industrial heritage tourism industry. The perspective which all three of these interviewees bring was enriched and simultaneously complicated by their business interests. LE7 and LE9 both attended the local university at some point in their lives so were also former students. LE8 owned a great amount of property with historical mines and has had professional surveys of his land through Ottawa National Forest and the Porcupine Mountains State Park. Archaeologists had also examined some of the mines on his property. There was a strong presence of preservation ethic and historical interest on the part of LE8, as well.

The two property holders, LE8 and LE9, were for restricting mineral collection on the site and against remediation at the Cliff Mine site. LE7 was more ambivalent about both issues which could indicate that property ownership in a business venture strengthens feelings of property security, especially when that property has been trespassed on as in LE8 and LE9's cases. Property ownership seems to pull the owner to one side or another on the issues of mineral collection and remediation depending on the economic purpose of the property or the individual experiences of the owner.

All three respondents in the Commercial Sector were supportive of archaeology and preservation and in addition were very aware of the historical importance of the Cliff Mine. LE7 and LE9 advocated a minimalist approach to interpreting sites like Cliff Mine while LE8 concentrated on full archaeological exploration and research. LE9 and LE8 
own historic mines and were thus strongly opposed to mineral collecting from private property. LE7 and LE9 were also advocates of supporting and linking heritage businesses to archaeology and heritage events. All of these business owners have complementary yet competing interests in the Keweenaw.

\section{Conclusions}

Delineating individuals into stakeholder groups was complicated because many people play multiple roles in local affairs, as examined above. The individuals interviewed throughout this chapter comprise a group of select community members who provided perspectives on heritage, the Cliff Mine, and their own identities. The subgroups were then classified into representative positions that these people hold in their community based on their responses in the interviews. Their opinions and values affect heritage, specifically the Cliff Mine, as it remains an industrial heritage site with no current preservation plan.

Every respondent believed that the Cliff Mine should be preserved: either as it is now or as an interpreted heritage site, owned or managed by someone. There was little ambiguity on this issue yet each respondent held a different idea of what the Cliff's future will be like. Some shared ideas on how to interpret the Cliff's history on-site and some felt that interpretation would be conducted as soon as the site was securely owned with the purpose of being preserved. No matter how long they believed it would take, all respondents shared a desire to see the site managed.

There was one issue that divided many of the respondents, that of mineral collecting. Respondents from the Government and Commercial Sectors were the most adamant about restricting mineral collecting. LE7 was the only respondent from these sectors that did not mind it. Even respondents from the Cultural Sector felt that there should be some mineral collecting allowed but drew the line at artifact collection. Four out of seven of the survey interviewees listed Rock Collecting as an activity they enjoyed at the Cliff Mine. The remaining survey interviewees understood the draw of mineral collecting and did not mind that it happened.

Mineral collecting may be one of the most contentious aspects of managing the 
Cliff Mine as a heritage site in the future. Waste products at the Cliff Mine cover building foundations and possibly contain artifacts that have value as research materials. The displacement of these mineral piles could impact the context of such artifacts. This is why many heritage managers and archaeologists would restrict mineral collecting and metal detecting at sites like the Cliff Mine. However, limiting activities at sites that have been perceived as open to the public, like the Cliff, would be difficult. Interviewees such as LE8 and LE9 underscored their difficulties in keeping mineral collectors from taking home their property. According to many interviewees, such as LE2 and LE7, it would be a misstep to restrict mineral collecting completely.

The issue of environmental remediation is similar to that of mineral collecting in its contentiousness. Money exists for the remediation of stamp sands from Eagle River watercourses $^{9}$, but there is a concern for the destruction and removal of important archaeological features by doing such remediation. Interviewees LE2, LE7, and LE3 questioned the process of remediation and its effectiveness. LE8 and LE9 were less than convinced that remediation would have an impact on a site that has been polluted with copper for over 150 years. Only respondent LE1 had a positive view of remediation as she valued the environment of the Cliff site in a different way than others.

Mineral collecting and environmental remediation represent two drastically different yet high-impact activities that could affect the Cliff Mine's future as a heritage site. Responses collected through the interviews in this chapter were a first step in understanding how different stakeholders in the community see such activities. What is known from these data is that most respondents greatly value their heritage, even if the heritage was not passed down through relatives. The Keweenaw is a place that holds value for many reasons; to visitors and especially to those who consider themselves local.

\footnotetext{
${ }^{9}$ Houghton/Keweenaw Conservation District is the organization which has sought federal funding to remediate the stamp sands as a part of the Eagle River Watershed project in Houghton Township, Keweenaw County; information retrieved from: http://www.hkconserve.com/news/support.php. Sean Gohman mentions the project and federal compliance in the Cliff Mine Blog at the following link: http://cliffmine.wordpress.com/2011/07/14/june-15th-a-visitfrom-tv-and-a-very-important-guest-lecture/
} 


\section{CHAPTER SIX}

CONCLUSION

The analyses and results of both the Cliff Mine tour survey and semi-structured interviews have revealed valuable insights into who attends industrial heritage site tours and why, as well as how the Keweenaw community values those industrial heritage sites. In this chapter, an analysis of opinions collected about the tour will be made using an ASEB Grid model with suggestions for improving the quality of the outreach at field school tours. In this chapter, I have concluded on broadening heritage outreach, improving the survey, and conducting future research. Important findings from each data set are compared and contrasted to published works. At the conclusion to this chapter, suggestions for future research are made.

\section{Demographic Questions}

Within the demographic data there were certain groups who were underrepresented. In the age category, some of the lowest percentages were in the three groups between 18 and 45 years of age. White-collar-employed respondents outnumbered blue-collar employees by a ratio of $4: 1$. The young adults who did attend the Cliff Mine tours tended to be local MTU students or MTU alumni. Few service industry workers attended even though the majority of the population in both Houghton and Keweenaw Counties are service industry workers, including tourism-related employment. Additionally, visitors from Baraga and Ontonagon Counties were underrepresented or absent; these are counties which border Houghton County.

\section{Qualitative Questions: Tour Analysis}

One research question sought to know who attended industrial heritage site tours and what these visitors valued. From analyzing the demographic and qualitative data, a visitor profile formed. Participants arrived at the site with an interest in history and local heritage and could readily identify other local industrial heritage sites. Generally, participants had ancestors or relatives (including themselves) who worked in the mining industry and this ancestry influenced their interest in industrial heritage. Most participants 
were not members of history, heritage, or archaeological groups and organizations, but when they were, it was typically a membership in the local Keweenaw County Historical Society (KCHS). This historical society owns and actively preserves over 10 properties in Keweenaw County and is a visible local group.

Participants were positive and pro-preservation with very few negative or critical responses. They were concerned with the disappearance of history, felt that historical sites offered educational opportunities, and wanted to know more about the social lives of the people who once populated such sites. The qualitative data partially answered the first research question; the perceptions and values of Cliff Mine tour visitors related to archaeology and industrial heritage are now generally known. The remaining research questions were answered through interview data, however, the survey data is useful for another purpose: improving field school tour outreach.

An important aspect to conducting this research was how the tour can be improved from a heritage management and an archaeological perspective. Using a model developed by Alison J. Beeho and Richard C. Prentice, an analysis can be made of the consumption (1997:76) of, in this case, outreach. This model combined a modified version of SWOT Analysis, used often in business management (1997:77), and ASEB Grid Analysis. ASEB stands for Activities, Settings, Experiences, and Benefits. The authors used only the S and W from SWOT (Strengths and Weaknesses), altering their model to an ASEB Demi-Grid Analysis. Coded responses from interviews were placed in an ASEB Demi-Grid. Responses from the Cliff Mine tour survey were placed in the grid in an interpretation of the ASEB Demi-Grid model. This interpretation was based on the responses to select qualitative survey questions (TABLE 6.1). By using the ASEB DemiGrid model, the goal was to improve outreach at field schools by identifying both weak and strong aspects of the Cliff Mine tour and offering solutions.

\section{$\underline{\text { Demi-Grid Analysis }}$}

The responses from two pre-tour questions and seven post-tour questions were used to fill this grid. The selected questions were chosen because of the response content and applicability to the improvement of the tour. The organization of these responses 
TABLE 6.1

ASEB DEMI-GRID ANALYSIS OF CLIFF MINE TOUR SURVEY RESPONSES

\begin{tabular}{|c|c|c|c|c|}
\hline & $\begin{array}{l}\text { Activities } \\
\text { (tour, questions, } \\
\text { interactivity) }\end{array}$ & $\begin{array}{c}\text { Setting } \\
\text { (environment, } \\
\text { interpretation) }\end{array}$ & $\begin{array}{c}\text { Experiences } \\
\text { (exploring, excavation, } \\
\text { learning) }\end{array}$ & $\begin{array}{c}\text { Benefits } \\
\text { (history, preservation) }\end{array}$ \\
\hline Strengths & \begin{tabular}{|l} 
Positive comments (80) \\
Enjoyed tour (22) \\
Guides were good (19) \\
Guides answered \\
questions (12) \\
Mineral collecting (5)
\end{tabular} & $\begin{array}{l}\text { Good information (26) } \\
\text { Landscape/beauty (3) } \\
\text { Outdoors (2) }\end{array}$ & $\begin{array}{l}\text { Positive (146) } \\
\text { Excavation (13) } \\
\text { Sense of place (7) } \\
\text { First time at the Cliff (3) }\end{array}$ & $\begin{array}{l}\text { History (114) } \\
\text { Support for preservation } \\
(38) \\
\text { Open to the public (5) }\end{array}$ \\
\hline Weaknesses & $\begin{array}{l}\text { Want to volunteer (7) } \\
\text { More from students (3) } \\
\text { Guide needs to speak up } \\
\text { (3) } \\
\text { More guides (2) } \\
\text { Tours too large (2) } \\
\text { Issues with crew (2) } \\
\text { Did not answer questions } \\
\text { (1) }\end{array}$ & $\begin{array}{l}\text { Need visual } \\
\text { aids/interpretation (29) } \\
\text { Want to know more (7) } \\
\text { Difficult hike for older } \\
\text { adults (1) }\end{array}$ & $\begin{array}{l}\text { Negative (9) } \\
\text { Want to learn more (3) } \\
\text { Excavation covered up too } \\
\text { soon (1) } \\
\text { Not enough about } \\
\text { archaeology (1) }\end{array}$ & $\begin{array}{l}\text { Nothing about Clifton (10) } \\
\text { Nothing about social history } \\
(8) \\
\text { Brings in collectors (3) } \\
\text { Nothing about prehistory (1) } \\
\text { Already enough sites (1) }\end{array}$ \\
\hline
\end{tabular}

concentrated on how the response contributed constructive changes to future outreach. I used only the responses helpful for improving outreach; responses deemed vague or unrelated to the tour itself were excluded.

\section{Strengths Activities}

For this area of the ASEB Demi-Grid, positive responses were collected which referenced the tour's quality, questions asked by participants, and the interactivity between the archaeological field school tour guides or students and visitors. Eighty general positive comments were counted and included to give an idea of the satisfaction level visitors had with the tour. Twenty-two responses indicated that the visitor enjoyed the tour and an additional 19 responses indicated that the guides were good. Twelve responses indicated that the tour guides and students answered their questions. Five 
responses mentioned mineral collecting.

\section{Weaknesses Activities}

Many of the weaknesses in the Activity area regarded aspects of the tour. Seven respondents requested that they be allowed to volunteer at the site in the future and three respondents asked that the students share more information. Two had issues with the crew on-site and felt ignored when they asked questions. Three said that the tour guide did not speak loudly enough and two felt that the tours were too large. Two felt the need for more guides and one mentioned students not answering specific questions.

\section{Strengths Setting}

Setting consists of the environment and interpretation on the tour. Strengths of this area were primarily the good information (26 responses) the tour guides shared with the visitors. Two responses mentioned being outdoors and three responses mentioned the landscape or beauty of the site.

\section{Weaknesses Setting}

Weaknesses in the area of Setting were focused primarily on the need for visual aids in the interpretation of the site. Twenty-nine responses asked for maps, brochures, and interpretive signs throughout the site. According to the findings of Cameron and Gatewood in their survey of Bethlehem, Pennsylvania, their respondents considered "explanatory signs" the most important aspect of visiting historic sites followed closely by "guided tours" and "hands-on displays" (2000:115). Seven respondents wanted more interpretation and to know more about the site. One response indicated that the tour hike was difficult for older adults.

\section{$\underline{\text { Strengths Experiences }}$}

For the area of Experiences, responses were chosen that fit the areas of exploring, excavation, and learning. There were many positive remarks that fit into this category. Many of these responses were simple: "Yes, learned a lot," and "Yes, it was fascinating 
and historically exciting," are two sample responses that fit into the positive comments. Within the thematic extent of this category there were 146 positive comments about the experience of being on the tour. Thirteen responses cited the excavation as a strength of the tour experience. Seven responses mentioned the 'sense of place' that going to industrial heritage sites like the Cliff Mine gave them. Some indicated that it made them feel like more of a local or that they felt closer to the Keweenaw in some way through the experience. This is what Cameron and Gatewood would have called a numen experience at industrial heritage sites $(2000: 109,123)$. Three responses indicated that it was the respondent's first time at the Cliff.

\section{$\underline{\text { Weaknesses Experiences }}$}

Nine responses indicated a negative aspect of the respondent's experience and three wanted to learn more about the site in general. One indicated that the excavation was covered back up too soon and another felt that there was not enough information about archaeology in the tour.

\section{$\underline{\text { Strengths Benefits }}$}

The vast majority of responses in the area of Benefits indicated learning, enjoying, or preserving history was beneficial with these responses numbering 114 . Thirty-eight responses indicated that the support for preservation was an important benefit and five responses mentioned the fact that the site was open to the public as a boon.

\section{$\underline{\text { Weaknesses Benefits }}$}

Weaknesses in the area of Benefits were focused on social aspects of the site that were neglected. Ten respondents specified that there was little information, if any, about Clifton and eight were more general and remarked that there was little to nothing said about social history. Three responses warned that collectors and destructive people would now know where to find parts of the site to dismantle. One respondent wanted to know more about the prehistoric occupation of the area. Another said that there were already enough preserved heritage sites in the area without Cliff adding to the numbers. 


\section{$\underline{\text { Tour Improvements }}$}

From the results of the ASEB Demi-Grid analysis, several suggestions can be made to advance future archaeological field school outreach at industrial heritage sites in the Keweenaw. Adjusting the tour group sizes so that all participants can hear and ask questions would be a good first improvement. Interpretive handouts which highlighted key areas of the site (such as powder houses, shafts, and landscape features) could be used to fill the need participants expressed regarding interpretive signage. If withholding such interpretation is the best course of action for the site, visitors should know why there are no maps or signs.

Visitors should be actively involved in the preservation of the site and should feel included in what is happening at the Cliff Mine. Handouts made by the archaeologists working at the site that direct visitors to printed materials and the Cliff Mine blog have the potential to engage visitors. The potential for collectors to destroy the site is high, with many areas already picked through thoroughly. A handout could also inform visitors of the disruption of the archaeological record that happens when collecting pits are dug and about the archaeological ethics of collecting artifacts. Handing a visitor this document, or even a generalized map handout, allows those working at the site to control some of the information disseminated to visitors about the Cliff Mine.

To inject more archaeological information into the tour, students could explain what they are doing on-site. Some visitors on-site claimed that the students were shy or did not talk a lot about what they were doing. If a visitor to an archaeological site is not given information about basic archaeological methodology, including site stratigraphy and the clearing of each unit level-by-level, why even show them the excavation? The great amount of emphasis on history is probably not the information expected from an archaeological site tour. The archaeological education and technical aspects of field school outreach should be improved on for future tours.

Improving outreach in the area of social history may be a much easier feat once that information is uncovered in the Clifton area. However, some information about the social lives of miners and residents in the area is known and can be disseminated to tour groups. It is possible that visitors would be satisfied by tour guides and students 
discussing potential projects through the MTU Social Sciences department and what those projects may tell us about life in the area. The field school crew could also read Copper Country Journal (Hobart 1991) and learn about the lives of the people of Clifton themselves so that when visitors ask, they are prepared to share what they have learned.

\section{Conclusions on the Cliff Mine Survey}

Utilizing the model of the pre- and post-tour survey could be applied to many different environments; however, there are improvements that should be made. The survey can be shorter and more specific to truly gauge how differently visitors feel before and after their tour. In addition, it would be beneficial to collaborate with tour guides to target specific facets of outreach that visitors ideally would retain.

In a second round of survey research, I would increase the number of demographic questions to include salary, education, and whether or not the individual had been born in the area. The resulting demographic data from these questions would be compared directly to existing industrial heritage site survey data for a more complete profile of Cliff Mine visitors. Questions about the quality of the tour would remain, however, questions about other heritage sites and proposed activities at such sites would be removed. I would focus on the Cliff Mine as a heritage site and the ways in which visitors imagine it as a preserved heritage site or tourist attraction.

Visitors to the Cliff Mine tour were demographically similar to heritage site visitors in other areas of the United States (TABLE 6.2). In this table are data from Cameron and Gatewood's survey of Bethlehem, Pennsylvania (2000), Essex National Heritage Area (Stynes and Sun 2004a), Lackawanna Valley National Heritage Area (Stynes and Sun 2004b), The Lowell Experiment (Stanton 2006), and the Cliff Mine tour survey. Some of the unique demographics at the Cliff Mine tour are the number of firsttime visitors and the large number of people who cited the local newspaper as a media source used to find out about the tour.

The large number of first time visitors is easily explained by the fact that the Cliff Mine field school tour only happened once before the 2011 season. Many visitors had probably been casual visitors to the Cliff Mine prior to the tour. A more appropriate 
TABLE 6.2

COMPARISON OF REPORTED DATA FROM FIVE HERITAGE SITE SURVEYS

\begin{tabular}{|c|c|c|c|c|c|}
\hline & $\begin{array}{l}\text { Bethlehem, } \\
\text { PA Visitors } \\
\text { Survey }\end{array}$ & $\begin{array}{c}\text { Essex NHA } \\
\text { Report }\end{array}$ & $\begin{array}{c}\text { Lackawanna } \\
\text { Valley NHA } \\
\text { Report }\end{array}$ & $\begin{array}{l}\text { The Lowell } \\
\text { Experiment }\end{array}$ & $\begin{array}{c}\text { Cliff Mine Tour } \\
\text { Survey }\end{array}$ \\
\hline $\begin{array}{l}\text { Ages } 46 \\
\text { and up }\end{array}$ & $35 \%+{ }^{\mathrm{a}}$ & $75 \%$ & $79 \%$ & N/A & $61 \%$ \\
\hline $\begin{array}{l}\text { Gender } \\
(\mathrm{M} / \mathrm{F})\end{array}$ & $\begin{array}{l}42 \% / \\
58 \%\end{array}$ & $\begin{array}{l}32 \% / \\
68 \%\end{array}$ & $\begin{array}{l}39 \% / \\
61 \%\end{array}$ & $\begin{array}{l}43 \% / \\
57 \%\end{array}$ & $\begin{array}{l}53 \% / \\
47 \%^{b}\end{array}$ \\
\hline Local Pop. & $64 \%$ & $29 \%$ & $62 \%$ & $12 \%^{\mathrm{c}}$ & $65 \%{ }^{d}$ \\
\hline First Visit & N/A & $53 \%$ & $28 \%$ & $58 \%$ & $94 \%{ }^{\mathrm{e}}$ \\
\hline $\begin{array}{l}\text { Media } \\
\text { Sources }\end{array}$ & N/A & $\begin{array}{l}\text { Tourist Info: } 22 \% \\
\text { Newspaper: } 13 \%\end{array}$ & $\begin{array}{c}\text { Newspaper: } 28 \% \\
\text { Friends/Word of } \\
\text { Mouth: } 26 \%\end{array}$ & $\begin{array}{l}\text { Newspaper: } 7^{\mathrm{f}} \\
\text { Guide Book: } \\
4\end{array}$ & $\begin{array}{l}\text { Newspaper: } \\
53 \% \\
\text { Friends/Family: } \\
20 \%\end{array}$ \\
\hline
\end{tabular}

a: This percentage comes from those 50+ years old; those who were 30-49 were grouped separately

b: Percentages without non-answers included

${ }^{c}$ : Percentage calculated from raw numbers of Lowell/Lowell Area responses

${ }^{\mathrm{d}}$ : Percentage calculated from reported geographic residence, not local or non-local demographic

e: Percentage taken from question asking if respondent took the 2010 Cliff Mine Tour

f: Actual number of responses; newspaper was the highest followed by guide book

estimation of first time visitors could be extracted from the demographic data which asked what activities visitors enjoyed while at the Cliff Mine. Five percent of the responses to this question listed 'Nothing' as their favorite activity at the Cliff Mine, which might indicate that the respondent had never been there before. This leaves the remaining $95 \%$ of respondents having visited the Cliff Mine prior to the tour. If the Cliff Mine were a preserved industrial heritage site, this would mean that almost all of the visitors were repeat visitors. This would be a very unusual amount of repeat visitors to 
any industrial heritage site, particularly those used in this study (TABLE 6.2). An amount of repeat visitation that large certainly indicates that those who visit the Cliff Mine do so without interpretation or marked trails on a regular basis.

The popularity of the local newspaper as a media source is also easily explained through the unique nature of Cliff Mine tours. The Mining-Gazette is a regional newspaper that reaches four local counties; Houghton, Keweenaw, Ontonagon, and Baraga. Public day tours (as detailed in Chapter Three) only happen three weekends out of the year at the Cliff Mine site. Many of the respondents live in rural cabins and may not have access to the internet or to the Cliff Mine blog to read about upcoming public tours. They may instead rely on the local newspaper to find out about local events or trust that the newspaper reports on local events regularly. Regardless of the reason, visitors to the Cliff Mine tours cited the newspaper as a media source more often than any other cited heritage site survey which means that the newspaper is an effective form of outreach in the local context (TABLE 6.2).

One problem exists with the Cliff Mine's media outreach: the age of newspaper readers. All but four of the responses listing the newspaper as a media source were from respondents aged 46 and older. Internet sites, which are a popular information dissemination tool, only accounted for $5 \%$ of the media type responses. The Cliff Mine has a blog, but social media such as Facebook and Twitter may be a more effective avenue for reaching a younger and more internet dependent demographic. 'Status updates' and posts indicating when upcoming tour days will be held could help direct young adults to the Cliff Mine blog and to the site tour days. By posting digital photos taken at the site of MTU students working, the viewership might become more interested in actually seeing what is happening on-site.

Qualitative questions in the Cliff Mine tour survey were inspired by both public archaeology and industrial heritage research. One such study, English Heritage Industrial Heritage at Risk Public Attitudes Survey, asked nearly 2,000 English citizens their opinions on industrial heritage. Respondents from the English Heritage survey and the Cliff Mine survey both greatly valued industrial heritage and archaeology (2011:15). In the English Heritage survey, industrial heritage was seen as a part of a national identity 
with some local identities highlighted (particularly Northeast England) whereas in the Cliff Mine survey, industrial heritage was seen as a part of local Keweenaw identity. There were also responses about the connection that industrial heritage gives people to their local area in both surveys but a rather small portion of the overall responses in the English Heritage survey mentioned the link to family history whereas in the Cliff Mine survey, almost half of the respondents claimed this link.

Some of the most common responses about the value of industrial heritage in the Cliff Mine survey are similar in the English Heritage survey. These responses are about learning and understanding with themes such as: "history is important for future generations," "is important to learn about," "is a reminder or window into the past," and "is good to tell the next generation so they never forget." Many respondents in both surveys were aware of other industrial heritage sites, either in their area or nationally, and could name or identify them. Responses in both surveys also mention protecting industrial heritage because it is "at risk," "it will disappear," or that "we have lost enough history already and cannot afford to lose any more.” Overall, all respondents were supportive of preserving industrial heritage for social, economic, and educational reasons.

In The Lowell Experiment, Stanton asked corresponding questions to those in the Cliff Mine tour survey. One question asked respondents about their familial connections to industrial heritage. Stanton found that around half of her respondents identified as having a family history in industry, similar to the results in the Cliff Mine tour survey (2006:161). Stanton also found high numbers of visitors were employed in education, which was the second most common occupation of respondents to the Cliff Mine tour survey (2006:160).

\section{Conclusions on Interviews}

Interview data showed that visitors and local experts alike have an interest in not only industrial heritage but the preservation of that heritage in the Keweenaw. Interviewees had varying ideas for how to accomplish preservation but the ideas were generally indicative of their feelings towards the Cliff Mine. Examples of these ideas were to use new media types such as smart phone codes instead of interpretive signage or 
to add a trail system with interpretation in some areas. Some local experts wanted to preserve the site for reasons related to their identity within one of the three sectors (Government, Commercial, and Cultural).

Visitor perceptions and values were certainly influenced by their own identities as either local or non-local to the Keweenaw. This second research question was not answered entirely but aspects of individuality and group membership such as the concept of locality were crucial parts of visitor's connection to the Cliff Mine and to industrial heritage. Family industrial history was important at an individual level but was not a necessary element for interest in industrial history. The most important factor in the relationship between visitors and industrial heritage sites was an emotional connection which visitors were sometimes unable to articulate.

Each local expert had to negotiate their identities based on which role they were playing at a certain time, such as LE7 who fits within the Commercial Sector but has also fulfilled roles in the Government Sector and sees himself as fitting into the Cultural Sector. There are definitely conflicts between some of those roles, particularly when the aspect of locality or non-locality is factored in. Respondent LE2 discussed his localness as being forever marred by his association with the Government Sector even though he associated himself with the Cultural Sector. Further studies should broaden the variety of interview subjects within the Local Expert group. There are certainly more than three sectors of stakeholders that exist in the Keweenaw and these groups should be identified.

The interview section was inspired greatly by Cathy Stanton's The Lowell Experiment, but my semi-structured interviews asked questions about the nature of "being a local" because of the observed importance that it seems to have in the Keweenaw. Stanton also discussed tourism with her informants in the context of Lowell as a city "reborn" out of its single-industry past (2006). In my semi-structured interviews, heritage tourism came up frequently among local experts as either a booming, growing industry or as a sideline to outdoors tourism. Stanton also interviewed visitors to the Lowell National Historical Park (LNHP) and members of the local community and found that both groups of people had many similarities but also some key distinctions. Local 
residents had more blue-collar ${ }^{10}$ jobs than visitors but both groups were of diverse ethnic backgrounds.

In my interviews, local experts and visitor interviewees had diverse employment yet each group varied in their valuation and ideation of industrial heritage. A093, a retired engineer, imagined the Cliff Mine outfitted with a greeting station, trail maps, and interpretive signage; he also appreciated the "untouched" appearance of the area. Middleclass local business owner LE8 had a minimal-impact and collecting-restricted vision of the site even though he admitted to enjoying mineral collecting. Working-class A027 saw Plexiglas-covered excavations and mineral collecting areas set aside for hobbyists at the Cliff. Middle-class respondents LE1 and LE3 had similar ideas as those of LE8 but knew much more about the politics and formalities it would take to preserve the Cliff. Each interviewee supported preservation but their ideas about how it should be executed were often different. The third research question cited in page four of this work has only been answered partially. Future research should expand on these ideas and explore their relation to class and locality, particularly how these facets of identity influence the values and perceptions of industrial heritage.

Where Stanton focused on ethnicity and class ${ }^{11}$, I focused my interviews on preservation values and identity. Interviewees in the local experts group were sometimes members of conflicting interest groups or had various public identities depending on how they were approached. The visitor stakeholder groups had aspects of the local expert stakeholder groups and vice versa; they were rather similar to each other when you remove visitation-based responses, as Stanton found among her visitor and expert groups. One such similarity was how each group negotiated their own local or non-local identities. An example of this is the idea, shared among both visitors and local experts, that a person must be born in an area to be a local but that being a local was something a person also earned.

The "erasure" of class conflicts and class issues from the interpretation of the past

\footnotetext{
10 For the purposes of this discussion, and in Stanton's work, blue collar jobs are those which do not require an advanced degree such as jobs in industry, construction, and service work. White collar jobs generally require an advanced degree or are clerical, that is, a "desk job". These two types of occupation are class distinctions.

${ }^{11}$ For the purposes of this discussion, class henceforth refers to either blue collar (working class) or white collar (middle class/professional class) work.
} 
is not a subject that was broached in any way in my semi-structured interviews but it was a strong theme in Stanton's interviews (2006:170). None of my local expert informants held "blue-collar" jobs and only two of the visitor interviewees claimed to. No interviewees mentioned class overtly, whether in the context of the Cliff Mine's past or in the present. In the Keweenaw, class and class conflict are often framed as existing in the past but are still quietly present in contemporary life. Compared to the demographic occupation data of the Cliff Mine tour survey which had a 4:1 ratio of white-collar to blue-collar workers, the visitor interviewee occupations are about the same in terms of class. Future research should expand the local community expert pool to include a broader range of economic classes.

Matthew Liesch (2011) conducted "photo-elicitation" research in Calumet, Michigan to study how members of the community perceived the boundaries of and valued the Keweenaw National Historical Park (KNHP). Liesch's findings suggested that class played a role in how people felt about historical features in and out of the KNHP's boundaries, including the language people used to describe those features (2011:507). White-collar respondents used the word "pride" more often to describe the KNHP and were more "likely to believe that Calumet's private sector has a vital role in the park." Blue-collar respondents tended to challenge the KNHP through coded language that disparaged the park or historic features and they also tended to disagree with the "improper allocations of resources and human capital," associated with the park. Whitecollar respondents focused on conceptual factors such as the park boundaries and participating in the KNHP whereas blue-collar respondents focused on the tangible aspects, like buildings, signs, and landmarks. This is interesting when compared to Cliff Mine visitors because most of the visitors who indicated a desire for interpretive signs and maps had white-collar occupations or were retired persons.

Outreach can be tailored to each of these relationship types at heritage sites in the Keweenaw. Creating tangible resources for outreach, such as maps, handouts, and signs, while also engaging visitors in the preservation of heritage could improve outreach efforts. As Liesch discovered, exploring class roles in communities such as Calumet, Michigan can produce valuable data on the different ways heritage is experienced and 
valued. Economic class, as measured through both occupation and self-identification, should play a large role in any future research associated with heritage site visitors in the Keweenaw as it plays an important part in the perceptions of value associated with the past and the best means of outreach.

\section{Future Research}

Understanding visitor profiles and values at heritage sites has been a focus of many tourism studies. When applied to an outreach setting, that is a not-for-profit sector of heritage management and public archaeology, it can tell us more than just why people visit these places. It is a mistake to include public outreach as a component of field research without a qualitative study of its efficacy. As Chapter Two shows, there is a significant lack of such study within the archaeological community at field sites, an absence that this study has improved upon. In the future, archaeological field schools will ideally include outreach methodology alongside the standard field methods that are currently the focus of such courses.

When planning this research, the original intentions were to assess outreach; however, the research turned out to be more general the more that was learned about visitors. This research has begun the groundwork for a more in-depth study of Keweenaw industrial heritage visitorship as well as a preliminary assessment of Keweenaw stakeholders and their values. Now that visitor profiles and values have been at least partially gauged, further research may fill in the gaps observed in the data, and improvements to outreach in the future can be re-assessed productively.

Some suggestions for future outreach efforts would be a targeted outreach plan for groups who are not outwardly interested in heritage. The age groups most underrepresented in the Cliff Mine tour survey demographics were younger adults. Several interest groups in the Keweenaw area were not targeted for inclusion at the tour such as members of mineral clubs and ATV/snowmobiling clubs. Groups such as these are active in the Keweenaw community and their opinions on issues of heritage and preservation should be recorded. These groups are also visitors to the site and collect from the site. They have physical impacts on the site, as well, and can affect the site's 
integrity. One of the largest groups of people in the Keweenaw consists of those who are employed in the service industry. This group was underrepresented at the Cliff Mine tour according to the demographic data. The service industry, outside of local universities and the local hospital, is the largest industry. It encompasses tourist attractions, hotels, restaurants, landscapers, and so on, yet many of these local people were not present for the public tours.

To create a valuable outreach impact on heritage site visitors in the Keweenaw, visitor groups must continue to be researched and their values and perceptions collected. Outreach efforts must be improved to create deeper connections between visitors and heritage sites, particularly those sites in need of preservation. Improving outreach tours and their content is crucial to creating and maintaining those connections. Visitor demographics may change slightly every year but through consistent measurement, diverse media, and an improved tour experience, visitors are sure to take away a valuable and unforgettable experience. 


\section{BIBLIOGRAPHY}

Beeho, Alison J. and Richard C. Prentice

1997 Conceptualizing the Experiences of Heritage Tourists: A Case Study of New Lanark World Heritage Village. Tourism Management 18(2):75-87.

Cameron, Catherine $\mathrm{M}$.

2000 Emergent Industrial History: The Politics of Selection. Museum Anthropology 23(3):58-73.

Cameron, Catherine M., and John Gatewood

2000 Excursions into the Un-Remembered Past: What People Want from Visits to Historical Sites. The Public Historian 22(3):107-127.

Chaput, Donald

1971 The Cliff: America's First Great Copper Mine. Sequoia Press, Kalamazoo, MI.

DeLing Andrews, Eleanor

2005 Cliff Mine Excavation Report, 1973-2005. Unpublished site report. Archives Manuscript Collection, MS-743. Michigan Technological University Archives and Copper Country Historical Collections, Houghton, MI.

English Heritage

2011 Industrial Heritage at Risk: Public Attitudes Survey. Prepared by BDR Continental for English Heritage.

Fink, Arlene and Jacqueline Kosecoff

1998 How To Conduct Surveys: A Step-by-Step Guide, 2nd Edition. Sage Publications, Inc., Thousand Oaks, CA.

Fink, Arlene

1995 How to Ask Survey Questions. Sage Publications, Inc., Thousand Oaks, CA.

Gohman, Sean

2010 A More Favorable Combination of Circumstances Could Hardly Have Been Desired: A Bottom to Top Examination of the Pittsburgh and Boston Mining Company's Cliff Mine. Master's Thesis, Department of Social Sciences, Michigan Technological University, Houghton, MI.

Groves, Robert M., Floyd J. Fowler Jr., Mick P. Couper and James M. Lepkowski 2009 Survey Methodology, 2nd Edition. Wiley, New York, NY.

High, Steven C., and David W. Lewis

2007 Corporate Wasteland: The Landscape and Memory of Deindustrialization. Cornell University Press, Ithaca, NY. 
Hobart, Henry

1991 Copper Country Journal: The Diary of Schoolmaster Henry Hobart, 1863-1864.

Philip P. Mason, editor. Wayne State Press, Detroit, MI.

Lankton, Larry

2010 Hollowed Ground: Copper Mining and Community Building on Lake Superior, 1840-1990. Wayne State Press, Detroit, MI.

Le, Yen, Brian Forist, and Steven J. Hollenhorst

2005 Keweenaw National Historical Park Visitor Study, Summer 2004. Visitor Services

Project, Report 158, National Parks Service.

Liesch, Matthew

2011 Partnerships and Photographs: Community Conceptions of Keweenaw National Historical Park. Geographical Review 101(4):497-517.

Lipe, William D.

2002 Public Benefits of Archaeological Research. In Public Benefits of Archaeology. Barbara J. Little, editor, pp. 20-28. University Press of Florida, Gainesville, FL.

1974 A Conservation Model for American Archaeology. The Kiva 39(3-4):213-245.

Little, Barbara J.

2002 Archaeology as a Shared Vision. In Public Benefits of Archaeology. Barbara J. Little, editor, pp. 3-19. University Press of Florida, Gainesville, FL.

2009 Public Archaeology in the United States in the Early Twenty-First Century. In Heritage Studies: Methods and Approaches. John Carman and Marie Louise Stig Sørensen, editors, pp. 29-51. Routledge, New York, NY.

Martin-Ruiz D., M. Castellanos-Verdugo, and Maria de los Ángeles Oviedo-García 2010 A visitors' evaluation index for a visit to an archaeological site. Tourism Management 31(5):590-596.

McDavid, Carol

2002 Archaeologies That Hurt; Descendants That Matter: A Pragmatic Approach to Collaboration in the Public Interpretation of African-American Archaeology. World Archaeology 34(2):303-314.

McGimsey, Charles R.

1972 Public Archaeology. Academic Press, Salt Lake City, UT.

Merriman, Nick

2004 Introduction. In Public Archaeology. Nick Merriman, editor, pp. 1-17. Routledge, London, England. 
Moyer, Theresa S.

2007 Learning through Visitors: Exhibits as a tool for encouraging civic engagement through archaeology. In Archaeology as a Tool of Civic Engagement. Barbara J. Little and Paul A. Shackel, editors, pp. 263-277. Altamira Press, Walnut Creek, CA.

Potter, Parker B.

1994 Public Archaeology in Annapolis: A Critical Approach to History in Maryland's Ancient City. Smithsonian Press, Washington D.C.

1997 The Archaeological Site as Interpretive Environment. In Presenting Archaeology to the Public: Digging for Truths. John H. Jameson, editor, pp. 35-44. Altamira Press Walnut Creek, CA.

Ramos, Maria, and David Duganne 2000 Exploring Public Perceptions and Attitudes about Archaeology. Prepared by Harris Interactive for the Society for American Archaeology.

Romanelli, E., and O.M. Khessina

2005 Regional Industrial Identity: Cluster Configurations and Economic Development. Organization Science 16(4):344-358.

Schutt, Russell K.

2008 Investigating the Social World: The Process and Practice of Research, 6th Edition. Pine Forge Press, Thousand Oaks, CA.

Silliman, Stephen W. and Katherine H. Sebastian Dring 2008 Working on Pasts for Futures: Eastern Pequot Field School Archaeology in Connecticut. In Collaborating at the Trowel's Edge: Teaching and Learning in Indigenous Archaeology. Stephen W. Silliman, editor, pp. 67-87. University of Arizona Press, Tucson, AZ.

Sørensen, Marie Louise Stig 2009 Between the Lines and in the Margins: Interviewing People About Attitudes to Heritage and Identity. In Heritage Studies: Methods and Approaches. John Carman and Marie Louise Stig Sørensen, editors, pp. 164-177. Routledge, New York, NY.

Stanton, Cathy

2006 The Lowell Experiment: Public History in a Postindustrial City. University of Massachusetts Press, Amherst, MA.

Storm, Anna

2008 Hope and Rust: Reinterpreting the industrial place in the late 20th century. Papers in the History and Philosophy of Technology. Royal Institute of Technology, Stockholm, Sweden. 
Stynes, Daniel, and Ya-Yen Sun

2004a Essex National Heritage Area Visitor Characteristics and Economic Impact Analysis. Department of Community, Agriculture, Recreation, and Resource Studies, Michigan State University.

2004b Lackawanna Valley National Heritage Area Visitor Survey and Economic Impact Analysis. Department of Community, Agriculture, Recreation, and Resource Studies, Michigan State University.

2005 Impacts on Visitor Spending on the Local Economy; Chesapeake \& Ohio Canal National Historical Park, 2003. Department of Community, Agriculture, Recreation, and Resource Studies, Michigan State University.

Zimmerman, Larry J.

2007 Unusual or "Extreme" Beliefs about the Past, Community Identity, and Dealing with the Fringe. In Collaboration in Archaeological Practice: Engaging Descendant Communities. Chip Colwell-Chanthaphonh and T.J. Ferguson, editors, pp. 55-86.

Altamira Press, Walnut Creek, CA. 


\section{APPENDIX A \\ PRE-TOUR SURVEY}

Thank you for choosing to participate in this study. If you do not wish to answer a particular question, you do not need to; however answering all of the questions will greatly improve future tours. You will also be asked to complete a follow-up survey at the end of your tour. **If you do not wish to participate in the follow-up survey, please do not fill this survey out.**

Name (OPTIONAL) :

Age Range: $18-25 \quad 26-35 \quad 36-45 \quad 46-55 \quad 56-65 \quad 66-75 \quad 76-85$ or above

Gender: M / F / N/A Occupation:

Did you attend a Cliff Mine Field School tour in 2010? Yes No

What geographic area do you reside in currently?

Which describes your residency best? Year-Round Part-Time Student Other:

Do you consider yourself local to the U.P. or non-local? Local Non-Local

Please read the questions below and answer to the best of your ability.

1. What activities do you enjoy at the Cliff Mine or Clifton sites?

Hiking Rock Collecting Snowmobiling ATV Snowshoeing

Exploring Other Collecting Photography Nothing Other:

2. What other archaeology and/or heritage sites do you have an interest in?

3. Do you belong to any heritage, historical, or archaeological groups or clubs? Have you ever participated in an archaeological "dig"? Please explain.

4. Have you or a relative/ancestor worked in mining/mining-related industries? Does this relate to your interest in the Cliff Site?

5. Is it important to you to be able to tour or participate at archaeological sites? Why?

6. Should protecting or preserving archaeological sites be a priority in the Keweenaw?

7. What do you expect to see or to learn about on your tour today? 
8. How did you learn about the Cliff Mine tour (ex: newspaper, radio, friends/family, etc.)?

9. Should there be more opportunities for participating in archaeology and heritage events in the Keweenaw?

10. If so, where would you like to see further public archaeology opportunities and what would you like to do there?

11. Do you have additional comments or concerns before you leave for your tour?

You will be asked to share your contact information (if you choose to disclose your name for further interviewing) at the end of the second survey. 


\section{APPENDIX B POST-TOUR SURVEY}

Thank you for choosing to participate in this study. Please fill out the questions below to the best of your ability. Please fill out this survey after your tour experience.

1. Would you participate in a tour of an archaeological site again? Why or why not?

2. How could your tour experience have been improved?

3. Were the questions you had about Cliff Mine answered? Please explain.

4. Did the tour have a satisfactory amount of information about archaeology? Were your expectations met?

5. Now that you have completed the tour, is it important to you to be able to tour archaeological sites? Why?

6. After viewing the Cliff site, should protecting or preserving archaeological sites be a priority in the Keweenaw? Please explain.

7. Should there be more opportunities for participating in archaeology and heritage events in the Keweenaw?

8. If yes to question 7, where would you like to experience public archaeology opportunities in the Keweenaw and what would you like to be able to do there?

9. In the future, where would you like to see more archaeology done at the Cliff Site? What research questions about the site would you like to see answered (ex: how long did workers stay at Cliff, etc.)?

10. From your experiences on the tour, do you think the archaeologists do a good job of incorporating people into projects like the Cliff? Why?

11. What other archaeology or heritage related activities might you engage in now that you have taken the Cliff Mine tour? What programs would you like to see available to the public in the future?

12. Do you have additional comments or concerns? Did we miss anything?

If you provided your name on the previous survey, can Natiffany Mathews contact you to discuss your answers to this survey and to ask related questions? Such interviews are an opportunity for you to elaborate on questions and clarify your answers beyond these surveys. 
If YES, please provide a phone number, indicating a good time for me to call, and an email address if available.

NO, I do not wish to be contacted in the future.

YES, please feel free to contact me in the future.

My Phone \# is: ( _ _ _ _ _ _ _ _ Time to Call:

Email: 


\section{APPENDIX C INTERVIEWEE PROFILES}

\section{Survey Respondents}

\begin{tabular}{|c|c|c|c|c|c|c|c|c|}
\hline Resp.\# & Age & Gender & Occupation & 2010 & $\begin{array}{l}\text { Geographic } \\
\text { Location }\end{array}$ & Residence & Local? & Activities at Cliff \\
\hline A010 & $26-35$ & $\mathrm{M}$ & Researcher & $\mathrm{N}$ & Houghton County & YR & $\begin{array}{l}\text { Non- } \\
\text { local }\end{array}$ & Nothing \\
\hline A027 & $46-55$ & M & Mechanic & $\mathrm{N}$ & Wisconsin & OOS & $\begin{array}{l}\text { Non- } \\
\text { local }\end{array}$ & Rock-Collecting \\
\hline A034 & $\mid 36-45$ & $\mathrm{~F}$ & University & $\mathrm{Y}$ & Houghton County & YR & Local & $\begin{array}{l}\text { Hiking, } \\
\text { Snowshoeing, } \\
\text { Exploring }\end{array}$ \\
\hline A053 & $66-75$ & $\mathrm{~F}$ & Retired & $\mathrm{N}$ & $\begin{array}{l}\text { Marquette/ } \\
\text { Houghton County }\end{array}$ & YR & Local & $\begin{array}{l}\text { Hiking, Rock- } \\
\text { Collecting, } \\
\text { Exploring, } \\
\text { Photography }\end{array}$ \\
\hline A070 & $\mid 18-25$ & $\mathrm{M}$ & Custodian & $\mathrm{N}$ & Houghton County & YR & Local & $\begin{array}{l}\text { Hiking, Exploring, } \\
\text { Photography }\end{array}$ \\
\hline A093 & $\mid 56-65$ & $\mathrm{~F}$ & Education & $\mathrm{N}$ & $\begin{array}{l}\text { Keweenaw } \\
\text { County/ } \\
\text { Pennsylvania }\end{array}$ & PT & Local & $\begin{array}{l}\text { Hiking, Rock- } \\
\text { Collecting, Birding, } \\
\text { Wildflowers }\end{array}$ \\
\hline A094 & $56-65$ & M & Retired & $\mathrm{N}$ & $\begin{array}{l}\text { Houghton } \\
\text { County/ Indiana }\end{array}$ & PT & $\begin{array}{l}\text { Non- } \\
\text { local }\end{array}$ & $\begin{array}{l}\text { Rock-Collecting, } \\
\text { Exploring, } \\
\text { Photography }\end{array}$ \\
\hline & & $\begin{array}{l}\mathrm{F}=\text { Female } \\
\mathrm{M}=\text { Male }\end{array}$ & & $\begin{array}{l}\mathrm{N}=\mathrm{No} \\
\mathrm{Y}=\mathrm{Yes}\end{array}$ & & $\begin{array}{l}\text { PT }=\text { Part-T } \\
\text { YR=Year-I } \\
\text { OOS=Visit }\end{array}$ & $\begin{array}{l}\text { me } \\
\text { Round } \\
\text { ing from }\end{array}$ & f State \\
\hline
\end{tabular}

Local Experts

\section{Cultural Sector}

LE1 - Seasonal resident and educator; runs non-profit organization in the Keweenaw; identifies somewhat as local

LE2 - Retiree, volunteer at Cliff Mine, and student; identifies as local LE3 -Heritage professional and student; identifies as local 


\section{Government Sector}

LE4 - Employee of a governmental agency; heritage professional; identifies as non-local

LE5 - Employee of a non-profit connected to a governmental agency; identifies as a "born in the Keweenaw" local

LE6 - Senior employee of a governmental agency; graduate student

\section{Commercial Sector}

LE7 - Small business owner (tourism) in Keweenaw area; identifies as local; former student

LE8 - Small business owner (tourism); property owner in Keweenaw area LE9 - Small business owner (tourism); property owner in Keweenaw area; former student 


\section{APPENDIX D INTERVIEW QUESTIONS}

\section{Survey Respondents}

- Since visiting Cliff this summer, have you thought much about your experiences on the tour or about the site?

- Did your experience this summer inspire you to attend other historical sites or to seek out new experiences like the Cliff tour?

- Did your experience at Cliff change how you saw archaeology before attending?

- Did your experience at Cliff change how you feel about preserving historical sites like the Cliff?

- You referenced [area] in the survey as a candidate for future archaeology projects at the Cliff. Is there a particular reason you are interested in this subject area or area of the site?

- Is the Cliff site important to you for any reason?

○ If yes: Do you think most people would say this is why Cliff is important to them?

If no: Do you think most people would say the same thing?

- Did you explore other regions of the Cliff site, such as the residences and cemeteries?

○ Yes: Which areas do you remember and why?

- If you could do anything you wanted and money was no object, how would you preserve Cliff?

- Many people who visit Cliff collect minerals from the rock piles. Is this a part of Cliff's heritage along with historical mining?

- Is tourism in the Keweenaw a successful industry?

- You indicated that you are a local/non-local to the Upper Peninsula. Would you mind talking about your choice?

- If local: Is there anything about the Keweenaw that you connect with?

- If non-local: Is there anything about the Keweenaw that makes you feel 
like a non-local?

Local Experts

- Is the Cliff site important to you for any reason?

- What does the future look like for the Cliff site?

- If you could do anything you wanted and money was no object, how would you preserve Cliff?

- What should the general public know about the preservation of sites such as Cliff, from experiences that you have had with preservation projects?

- Many people who visit Cliff collect minerals from the rock piles. Is this a part of Cliff's heritage along with historical mining?

- At Cliff, there have been talks of environmental testing and remediation, particularly of the stamp sands. What do you think about environmental remediation projects at historical sites like Cliff?

- Is tourism in the Keweenaw a successful industry?

- Would an increase in public heritage and archaeological outreach improve tourism in the Keweenaw?

- Are volunteering and community involvement important to your work in the Keweenaw and if so, how do you advertise or recruit for these activities? 


\section{APPENDIX E IRB AND PHOTOGRAPHIC REPRODUCTION APPROVAL}

Protocol \#: M0714

Protocol Title: "Public Archaeology at Cliff Mine Field School"

Approved Dates: April 4, 2011 through April 3, 2012

- Illustrations based on maps created by the US Geological Survey (USGS) are permitted under Fair Use. Figures include 1.1, 2.1, and 5.2.

- Reproductions from the program SPSS are licensed for use through MTU. Figures include 4.1 and 4.2.

- Reproduction from Mark Dice used with permission. Figures include 3.1.

- All other figures were created by the author. Figures include 5.1 and 5.3. 